\title{
Assessment of Opportunities to Increase the Recovery and Recycling Rates of Waste Oils
}

Energy Systems Division

Argonne National Laboratory

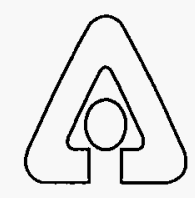

Operated by The University of Chicago, under Contract W-31-109-Eng-38, for the

United States Department of Energy

DISTRIBUTION OF THIS DOCUMENT IS UNLIMITED 


\section{Argonne National Laboratory}

Argonne National Laboratory, with facilities in the states of Illinois and Idaho, is owned by the United States Govemment, and operated by the University of Chicago under the provisions of a contract with the Department of Energy.

This technical report is a product of Argonne's Energy Systems Division.

For information on the division's scientific and engineering activities, contact:

Director, Energy Systems Division

Argonne National Laboratory

Argonne, Illinois 60439-4815

Telephone (708) 252-3724

Publishing support services were provided by Argonne's Information and Publishing Division.

\section{Disclaimer}

This report was prepared as an account of work sponsored by an agency of the United States Government. Neither the United States Government nor any agency thereof, nor any of their employees, makes any warranty, express or implied, or assumes any legal liability or responsibility for the accuracy, completeness, or usefulness of any information, apparatus, product, or process disclosed, or represents that its use would not infringe privately owned rights. Reference herein to any specific commercial product, process, or service by trade name, trademark, manufacturer, or otherwise, does not necessarily constitute or imply its endorsement, recommendation, or favoring by the United States Govemment or any agency thereof. The views and opinions of authors expressed herein do not necessarily state or reflect those of the United States Government or any agency thereof.

Reproduced directly from the best available copy.

Available to DOE and DOE contractors from the Office of Scientific and Technical Information, P.O. Box 62, Oak Ridge, TN37831; prices available from (615) 576-8401.

Available to the public from the National Technical Information Senvice, U.S. Department of Commerce, 5285 Port Royal Road, Springfield, VA 22161. 


\section{DISCLAIMER}

Portions of this document may be illegible in electronic image products. Images are produced from the best available original document. 


\section{Assessment of Opportunities to Increase the Recovery and Recycling Rates of Waste Oils}

\section{D.J. Graziano and E.J. Daniels}

Center for Industrial Technology, Energy Systems Division, Argonne National Laboratory, 9700 South Cass Avenue, Argonne, Illinois 60439 
This report is printed on recycled paper. 


\section{Contents}

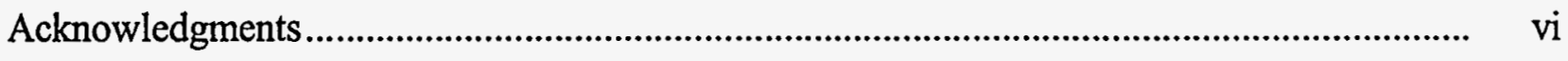

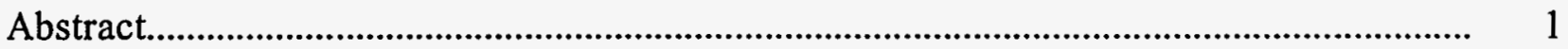

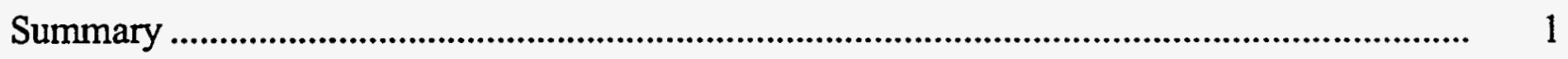

1 Research Needs ............................................................................................................... 5

1.1 Recover and Recycle Waste Oil Currently Disposed of ............................................. 5

1.2 Implement Source and Loss Reduction Methods ..................................................... 5

1.3 Develop and Foster an Effective Recycling Infrastructure ............................................. 6

2 Waste Oil Generation...................................................................................................... 8

2.1 Background............................................................................................................. 8

2.2 Need to Update Used Oil Generation Data ........................................................... 10

2.3 Waste Oil Challenges.................................................................................................. 14

3 Waste Oil Regulations and Incentives ............................................................................. 17

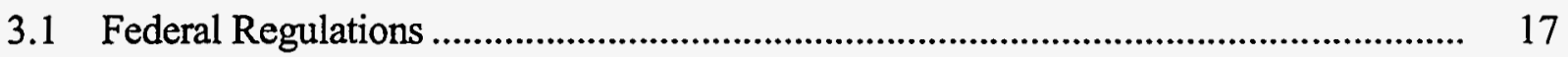

3.2 Federal Incentives............................................................................................. 18

3.3 State Regulations ............................................................................................. 20

3.4 State Incentives ............................................................................................... 22

4 Waste Oil Collection ..................................................................................................... 23

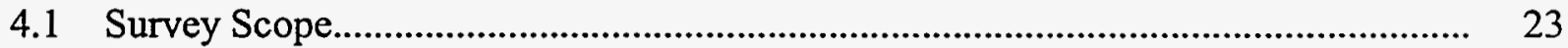

4.2 Needs and Opportunities Identified..................................................................... 24

4.3 Components of DIY Used Oil Collection Programs ................................................ 26

4.3.1 Sustained Funding ................................................................................ 26

4.3.2 DIY Participation............................................................................... 28

4.3.3 Limits on Liability............................................................................... 32

4.3.4 Technical Assistance for Collectors .............................................................. 34

4.3.5 Assessment ............................................................................................. 35

4.4 Opportunities for Government to Promote Collection Programs.............................. 36

$5 \quad$ Waste Oil Reuse Options................................................................................................. 37

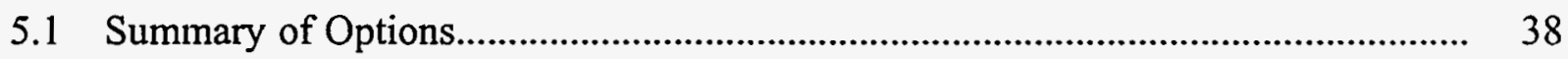

5.1 .1 Source Reduction...................................................................................... 38

5.1.2 Burning without Treatment......................................................................... 41 


\section{Contents (Cont.)}

5.1.3 Reprocessing to Fuel .................................................................................... 42

5.1.4 Reprocessing in a Primary Refinery to Produce Petroleum Products............ 43

5.1.5 Re-Refining to Lubricating Oil in a Dedicated Unit ......................................... 44

5.1.6 Re-Refining to Lubricating Oil in a Primary Lubricating Oil Refinery........... 46

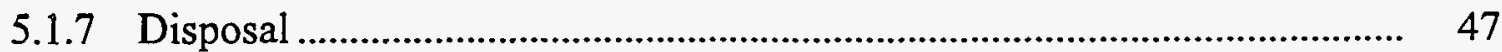

5.2 Energy Impacts ................................................................................................. 49

5.3 Environmental Impacts ................................................................................... 51

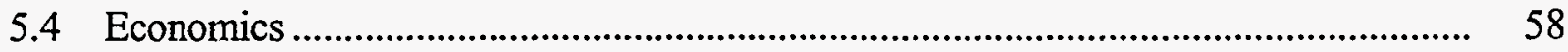

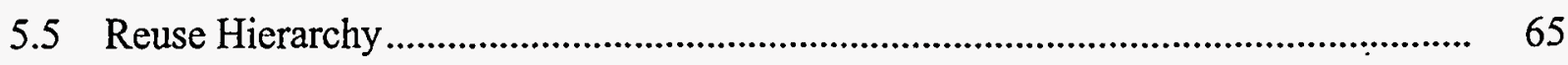

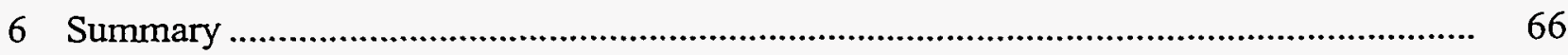

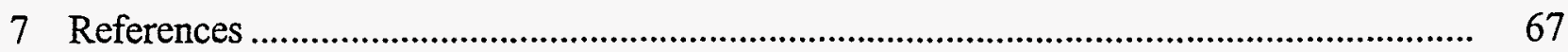

Appendix A: State Waste Oil Regulations and Incentives........................................................ 73

Appendix B: Waste Oil Study Contacts.............................................................................. 87

\section{Figures}

1 Estimates of 1991 Used Oil Flow in the United States .................................................. 11

2 Disposition of Lubricating Oils Sold in the United States............................................. 15

3 Potential Energy Savings of Meeting Waste Oil Challenges ................................................ 16

4 Vacuum Distillation/Hydrotreatment Re-Refining Process .................................................. 46

5 Direct Contact Hydrogenation Process......................................................................... 47

6 Solvent Extraction/Vacuum Distillation Process ................................................................. 48

7 Domestic Lubricating Oil Refinery and Re-Refinery Locations ......................................... 64

8 Hierarchy of Waste Oil Reuse Options ......................................................................... 65 


\section{Tables}

1 Domestic Consumption of Lubricating Oil.................................................................... 9

$2 \quad$ Waste Oil Generation Factors ......................................................................................... 10

$3 \quad$ North American Re-Refiners............................................................................................ 45

$4 \quad$ Energy Impacts of Waste Oil Reuse Options .................................................................. 50

$5 \quad$ Assessment of Re-Refining Energy, with Multiple Use Cycles Assumed....................... 52

$6 \quad$ Compositions of Used Oils and Other Fuels..................................................................... 54

$7 \quad$ Environmental Impacts of Waste Oil Reuse Options........................................................ 56

$8 \quad$ Economics of Waste Oil Reuse Options ........................................................................... 59

$9 \quad$ Economics of Re-Refining.......................................................................................... 62

10 Capacities of Domestic Lubricating Oil Refineries ............................................................... 63

A.1 State Waste Oil Regulations..................................................................................... 75

A.2 State Waste Oil Incentives ............................................................................................... 83 


\section{Acknowledgments}

This work is supported by the U.S. Department of Energy, Assistant Secretary for Energy Efficiency and Renewable Energy and Assistant Secretary for Policy, under contract W-31-109-Eng-38. We are grateful to Stuart Natof, Office of Industrial Technologies, and Hilary Smith, Office of Oil and Natural Gas Policy, for their management and guidance of this program. We would also like to acknowledge the many people listed in Appendix B who contributed their knowledge and experience to this report. Alan Gressel of the National Oil Recyclers' Association and Dennis Brinkman of Safety-Kleen are specifically acknowledged for their helpful input to and peer review of this report. The contributions and report review by the American Petroleum Institute, under the leadership of Bradley Jones, are also gratefully recognized. Finally, we would like to express our gratitude to Mary Fitzpatrick for technical editing. 


\title{
Assessment of Opportunities to Increase the Recovery and Recycling Rates of Waste Oils
}

\author{
by
}

\author{
D. J. Graziano and E. J. Daniels
}

\begin{abstract}
Waste oil represents an important energy resource that, if properly managed and reused, would reduce U.S. dependence on imported fuels. Literature and current practice regarding waste oil generation, regulations, collection, and reuse were reviewed to identify research needs and approaches to increase the recovery and recycling of this resource. The review revealed the need for research to address the following three waste oil challenges: (1) recover and recycle waste oil that is currently disposed of or misused; (2) identify and implement lubricating oil source and loss reduction opportunities; and (3) develop and foster an effective waste oil recycling infrastructure that is based on energy savings, reduced environmental impacts, and competitive economics. The United States could save an estimated $140 \times 10^{12} \mathrm{Btu} / \mathrm{yr}$ in energy by meeting these challenges.
\end{abstract}

\section{Summary}

This study, a review of literature and current practice relevant to waste oil generation, regulations, collection, and reuse, was undertaken to identify research needs and approaches to increasing the recovery and recycling of this resource. Annual domestic sales of lubricating oils for a variety of automotive and industrial applications total $2.4 \times 10^{9}$ gal. An estimated $1.4 \times 10^{9} \mathrm{gal}$ of waste oil is generated annually (with a total 0.19 quad heating valuel); of this volume, only about $75 \%$ is currently recovered and recycled (Dietly 1992). Current recovery methods should be continued and new methods developed to increase this recovery rate in order to reduce our energy consumption and protect the environment.

Estimates of domestic waste oil generation are based on methodologies developed in the 1970s and 1980s. Individuals and organizations with interests in waste oil have identified the need to update these estimates as an important issue. However, this need must be weighed against the cost of conducting a comprehensive national survey to collect the data required to develop new estimates. Our analysis suggests that regional estimates may be of more value at this time than national statistics. We propose an alternative approach - developing tools to estimatc regional waste oil volumes - to address the need for revised estimates.

${ }^{1} 1$ quad $=10^{15}$ Btu (one quadrillion British thermal units). 
On September 10, 1992, the U.S. Environmental Protection Agency (EPA) promulgated management standards for waste oil destined for recycling; these standards are designed to protect the environment without having to regulate used oil as a hazardous waste. The standards are commonly considered to be common sense, good housekeeping rules and are not expected to negatively affect the waste oil recycling industry. If EPA later determines that these standards are not adequately protective of the environment, some changes, including the possibility of classifying used oils as hazardous waste, may be implemented. Aside from a handful of states that regulate used oils as hazardous waste or have more restrictive composition requirements for burning used oils, no state regulations that represent future obstacles to waste oil recovery and recycling were identified. Landfill bans on used oil filters and directives favoring the purchase of re-refined oil, on the other hand, may signal future opportunities for expansion of industries dedicated to filter recycling and oil re-refining.

This study identified three challenges of waste oil recovery: (1) recover and recycle waste oil currently disposed of or misused; (2) identify and implement lubricating oil source and loss reduction opportunities; and (3) develop and foster an effective waste oil recycling infrastructure that is based on energy savings, reduced environmental impacts, and competitive economics.

The greater portion of the waste oil that is improperly disposed of is generated by do-ityourself (DIY) and off-road (farming, mining, and construction) sources. Surveys of public and private waste oil collection programs revealed many cost-effective program components and common needs. The DIY waste oil collection problem has been addressed by many initiatives; effective components of these programs are highlighted in this report. Research needs identified in this study include developing waste oil collection programs that target off-road generators and motivating do-it-yourself (DIY) oil changers to recycle used oil.

About one billion gallons ( 0.14 quad) of oil sold annually is regarded as "unrecoverable" (i.e., burned, leaked, consumed in use, or otherwise separated from the recoverable oil) (Dietly 1992). Opportunities for reducing these losses include (1) recovering oil retained in discarded oil containers and oil filters and (2) implementing engine design changes to reduce motor oil consumption during use and to prevent oil leaks. This study also identified several potential methods to reduce the total volume of lubricating oil consumed; however, additional research is needed to fully exploit this potential.

Source reduction is considered the "acme" of the reuse hierarchy - it should be the first goal in addressing the waste oil issue. However, because the energy value of waste oil can be effectively recovered, preventing waste oil disposal is also a priority. Research should focus on sustaining markets for waste oil and increasing the volume of waste oil re-refined ${ }^{2}$ to lubricating oil.

2 Re-refining refers to the process of cleaning and upgrading waste lubricating oil to produce a high-quality base oil; the base oil is then blended with additives. The product of this process is re-refined lubricating (lube) oil. 
Re-refining offers significant energy savings and fewer environmental impacts than other reuse options that generate such products as fuel, distillate oils, or gasoline. Capital costs and customer perceptions about the quality of re-refined products are major hurdles to re-refining waste oil. Both could be overcome if waste oil re-refining were integrated into existing lubricating oil refineries. Capital costs for hydrotreatment, product storage, sour gas processing, and pollution prevention would be minimized if existing refinery equipment could be employed for these services. A leading lubricating oil company endorsing re-refined oil by putting its brand name to it would have a significant positive impact on customer perceptions of product quality.

Re-refining within a lubricating oil refinery is not commercially practiced. Research is needed in the following areas to commercialize this option: (1) develop and demonstrate pretreatment technology required to integrate re-refining into a virgin lubricating oil refinery; and (2) identify used oil contaminants that deactivate hydrogenation catalysts, and if needed, develop technology for their removal and/or develop catalysts that are immune to deactivation by the contaminants. To ensure commercial viability of this technology, research and development work should be conducted in partnership with a lubricating oil manufacturer. 


\section{Research Needs}

This section describes the research needs relevant to each of the three waste oil challenges identified in this study. Background information and discussions of each of these needs are provided in Sections 4 and 5.

\subsection{Recover and Recycle Waste Oil Currently Disposed of}

If the energy value from all waste oils estimated to be disposed of or misused were recovered, the United States would realize an estimated energy savings of 62 trillion British thermal units (Btu) per year. Research efforts required to promote the recovery of waste oil include the following:

- Increase the availability and effectiveness of used oil collection programs by supporting the planning, startup, coordination, evaluation, and transfer of demonstration or pilot collection programs.

- Develop and pilot a survey or focus group protocol to determine how to motivate local do-it-yourself (DIY) oil changers to recycle their used oil.

- Implement programs to recover used oil generated by off-road (mining, farming, and construction) sources.

- Develop protocols to estimate the amount of used oil generated by DIY oil changers regionally and nationally, on the basis of an updated generation factor for used motor oil.

- Develop software for use by states or municipalities to estimate and track regional waste oil generation and the effectiveness of their recovery programs.

\subsection{Implement Source and Loss Reduction Methods}

A modest $10 \%$ reduction in the total consumption of lubricating oils would lead to cnergy savings of $33 \times 10^{12} \mathrm{Btu} / \mathrm{yr}$. Further energy savings could be realized through loss reduction. For example, the energy value of oil disposed of with used oil filters and containers is cstimated to be $6 \times 10^{12} \mathrm{Btu} / \mathrm{yr}$. The following research efforts could lead to source or loss reductions:

- Pilot a systems approach to used oil recovery that includes use of rcusable containers and recovery and recycling of filters, containers, and other oilcontaminated materials. 
- In cooperation with the plastics manufacturing and recycling industries, conduct a cost/benefit analysis of recycling options for oil-contaminated plastic containers to identify the technology needed to allow economical recycling of these containers and retained oil.

- In cooperation with the steel industry and filter manufacturers, conduct a cost/benefit analysis of recycling options to identify the technology development needed to allow economical recycling of used oil filters and retained oil.

- Through cooperative research between lubricating oil manufacturers and automobile engine designers, develop approaches to automobile engine oil source reduction to extend the useful life of oils, reduce oil consumption during use, decrease in-use contamination of oils, and/or reduce the volume of oil required in the crankcase.

- Implement the following measures to prevent the contamination of oils by particularly toxic components:

- Replace materials that leave toxic wear metals in oils;

- Minimize ingress of contaminants during use (e.g., combustion exhaust via blow-by in engines);

- Substitute less toxic components in the formulation of additive packages; and

- Promote regulatory and educational programs to minimize the mixing of waste oil with other materials.

- Develop effective, in-line oil sensors that provide feedback on oil performance in order to increase the interval between oil changes.

- Solicit and develop additional source and loss reduction ideas from the rescarch and industrial communities.

\subsection{Develop and Foster an Effective Recycling Infrastructure}

If all of the waste oil that is currently generated were re-refined to lubricating oil, an estimated $250 \times 10^{12} \mathrm{Btu} / \mathrm{yr}$ in energy would be saved through multiple use cycles. A more realistic short-term goal is to re-refine $25 \%$ of the total waste oil generated $\left(175 \times 10^{6} \mathrm{gal} / \mathrm{yr}\right.$ 
more than is currently re-refined). Energy savings of $36 \times 10^{12} \mathrm{Btu} / \mathrm{yr}$ would result. Research needs identified to meet this challenge include the following:

- Develop and demonstrate re-refining technology integrated within existing lubricating oil refineries.

- Evaluate the effect of waste oil contaminants on hydrogenation catalyst performance; specifically, identify components that lead to catalyst deactivation and develop technologies for their removal and/or develop more effective catalysts for waste oil re-refining.

- Support demonstration tests of re-refined oil use and, as necessary, support testing required to expand government and military uses.

- Investigate options for cost-effectively removing halogenated compounds from oil to increase the value of waste oils that contain halogens at high concentrations. 


\section{Waste Oil Generation}

\subsection{Background}

Lubricating oils derived from petroleum feedstocks are used in varied applications within two broad sectors: automotive and industrial. Automotive applications include crankcase oils, transmission fluids, and gear oils. Hydraulic oils, turbine oils, process oils, engine oils, and metalworking fluids are among the largest-volume industrial applications. Table 1 lists the volumes of lubricating oil used domestically in 1991, by specific application, as estimated by The Freedonia Group (Hayes 1992). These data are consistent with other published data (Bider 1985; Mueller and Associates, Inc., 1989).

The total volume of lubricating oil sold domestically, $2.4 \times 10^{9} \mathrm{gal} / \mathrm{yr}$, as reported by the National Petroleum Refiner's Association, is accepted by the petroleum industry to be accurate. This volume for 1991 is $2 \%$ less than the volume sold in 1981. The Freedonia Group estimates $2 \%$ growth in the total lubricating oil market over the next decade.

Typically, lubricating oils have a limited lifespan. Their performance deteriorates as the additives degrade or contaminants build up. Although in-line filtration and/or additive supplements can extend their useful life, eventually the oils degrade to a point where they must be replaced. Oils not consumed in use (e.g., burned, leaked, or used as feedstock) become "waste" or "used" oils. Although the term waste oil may carry a more negative connotation, these terms are considered equivalent and both are used in this report. The U.S. Environmental Protection Agency (EPA) defines used oil (40 CFR 260.10) as "any oil that has been refined from crude oil, or any synthetic oil, that has been used and as a result of such use is contaminated by physical or chemical impurities."

Estimating the volumes of waste oil generated and its disposition has challenged interested parties for many years. A study conducted for EPA by Franklin Associates from 1981 to 1984 has become a standard for these estimates (Bider 1985). Waste oil generation volumes are estimated by applying waste oil generation factors to lubricating oil sales figures. These factors, reprinted in Table 2, are based largely on surveys conducted in the 1970s (Weinstein 1974). These surveys include the following:

- Waste oil study of the Pittsburgh area, including interviews with employees of 83 service stations, representatives of various industrial organizations, and waste oil collectors and processors;

- Telephone survey of 92 collectors and processors of waste oil; and

- Telephone surveys and visits to organizations in 57 major Standard Industrial Classification (SIC) groups. 
TABLE 1 Domestic Consumption of Lubricating Oil

\begin{tabular}{lc}
\hline \multicolumn{1}{c}{ Oil Classification } & $\begin{array}{c}1991 \text { Lubricating } \\
\text { Oil Sales } \\
\left(10^{6}\right.\end{array}$ \\
gal/yr $)$
\end{tabular}

Source: Hayes 1992. 
The most recent waste oil generation estimates were published by Clayton Environmental Consultants in 1991 (Dietly 1992) and are reprinted with permission in Figure 1. These data are considered to be the best available without extensive additional research and have been adopted for this study with one change for 1993. The estimate of waste oil burned has been reduced to $690 \times 10^{6}$ gal to reflect increased re-refining and reprocessing to other petroleum products.

The estimated volume of oil rerefined in 1993 has increased to $170 \times 10^{6} \mathrm{gal} / \mathrm{yr}$ as Safety-Kleen continues to load its East Chicago, Indiana, re-refinery; this facility has a capacity of $85 \times 10^{6} \mathrm{gal} / \mathrm{yr}$. Also, two major oil companies, Lyondell and Texaco have recently begun re-processing waste oil. Since 1992, Lyondell has been feeding waste oil to a petroleum coker in its Houston, Texas, refinery. The company processed $3.5 \times 10^{6}$ gal of waste oil in 1993 and plan to process $12 \times 10^{6} \mathrm{gal}$ in 1994 (Wulfers 1994). In May 1994, Texaco started up a plant in Marrero, Louisiana, with the capacity to process $50 \times 10^{6} \mathrm{gal} / \mathrm{yr}$ of waste oil into marine diesel fuel. Texaco is also piloting a program to process waste oil in a petroleum coker located at its Delaware refinery.

\subsection{Need to Update Used Oil Generation Data}

Although the 1991 data from the Clayton study have been adopted for this study, the accuracy of these estimates has been questioned, even by their originator (Dietly 1992). The waste oil generation factors developed two decades ago may not reflect developments in lubricant formulations, uses, and end-of-life handling.

TABLE 2 Waste Oil Generation Factors

\begin{tabular}{|c|c|}
\hline Oil Classification & $\begin{array}{l}\text { Waste Oil } \\
\text { Generation } \\
\text { Factor }\end{array}$ \\
\hline \multicolumn{2}{|l|}{ Automotive Oils } \\
\hline \multicolumn{2}{|l|}{$\begin{array}{l}\text { On-Road Engine Oils } \\
\text { Personal vehicles }\end{array}$} \\
\hline DIY oil changers & 0.67 \\
\hline Non-DIY oil changers & 0.67 \\
\hline \multicolumn{2}{|l|}{ Commercial vehicles } \\
\hline Cars and light trucks & 0.66 \\
\hline Trucks and buses & 0.59 \\
\hline \multicolumn{2}{|l|}{ Off-Road Engine Oils } \\
\hline Farm & 0.59 \\
\hline Construction & 0.59 \\
\hline Mining & 0.59 \\
\hline Government & 0.63 \\
\hline Aviation & 0.47 \\
\hline \multicolumn{2}{|l|}{ Hydraulic Fluids } \\
\hline On-road vehicles & 0.10 \\
\hline Off-road vehicles & 0.75 \\
\hline Automotive Grease & 0.00 \\
\hline \multicolumn{2}{|l|}{ Industrial Oils } \\
\hline \multicolumn{2}{|l|}{ General Industrial Oils } \\
\hline Hydraulic & 0.76 \\
\hline Gear & 0.59 \\
\hline Turbine & 0.59 \\
\hline Refrigeration & 0.32 \\
\hline Way & 0.60 \\
\hline Compressor & 0.60 \\
\hline Rock drill air tools & 0.60 \\
\hline Other & 0.73 \\
\hline \multicolumn{2}{|l|}{ Process Oils } \\
\hline Rubber & 0.10 \\
\hline Electrical & 0.27 \\
\hline White & 0.10 \\
\hline Other & 0.10 \\
\hline \multicolumn{2}{|l|}{ Industrial Engine Oils } \\
\hline Marine & 0.50 \\
\hline Natural gas & 0.20 \\
\hline Railroad diesel & 0.20 \\
\hline \multicolumn{2}{|l|}{ Metalworking Fluids } \\
\hline Metal removing & 1.00 \\
\hline Metal forming & 0.60 \\
\hline Metal treating & 0.60 \\
\hline Metal protecting & 0.10 \\
\hline Industrial Grease & 0.00 \\
\hline
\end{tabular}

Source: Bider 1985. 


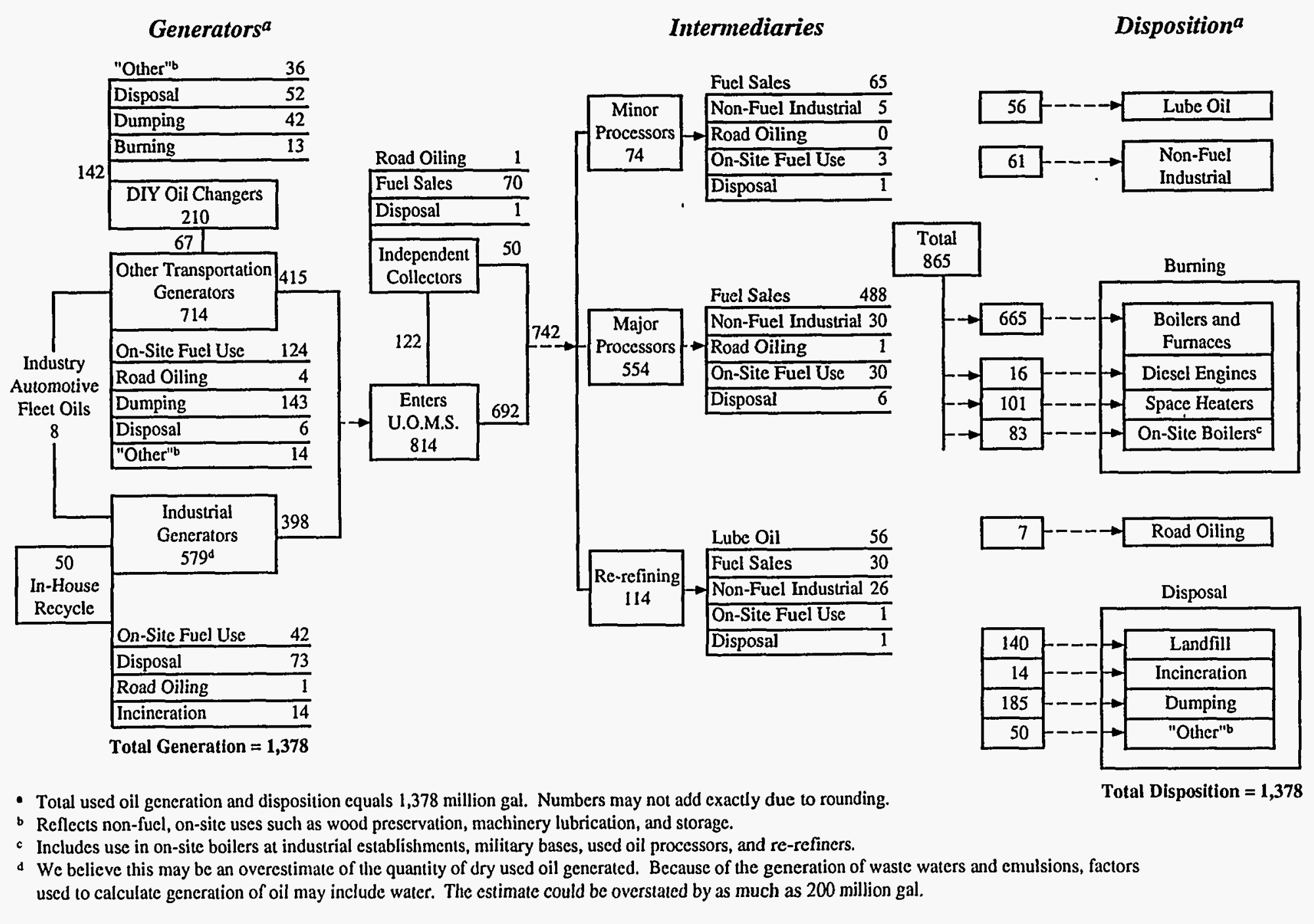

FIGURE 1 Estimates of 1991 Used Oil Flow in the United States 
The need to update the waste oil generation factors has been identified as an important issue by those who generate, recycle, and regulate waste oil. However, the costs and effort required to accurately update these data will be significant. For this reason, financial assistance from the government has been sought to.conduct the required work.

The value of having more accurate waste oil generation data must be weighed against the costs of obtaining these data. Any program to collect the data and update the waste oil generation factors would require an extensive, statistically based national survey. Waste oil generation factors cannot be derived from theoretical studies or data typically found in the literature.

For this study, an attempt was made to assess the accuracy of just one of these factors: the factor for automobile crankcase oil. Two methodologies were attempted: an accounting of the oil consumed during engine testing conducted by automobile or lubricating oil manufacturers, and actual operating experience of large car fleets. Rather than conducting a comprehensive survey, we contacted a limited number of relevant companies. The companies contacted were either unwilling or unable to provide the required data. This experience foretells the difficulties that will be encountered in completing a national survey.

Lubricating oil does not appear to be a pressing issue for most businesses. Many companies may not maintain accurate records of lubricating oil consumed and waste oil generated. The data from any survey, if supplied at all, might be suspect. To help ensure good results, the survey size would need to be increased to compensate for missing or inaccurate data.

Given the anticipated high cost of developing more accurate waste oil generation data, researchers must assess the needs for these data, including the following:

- To quantify the environmental and lost energy impact of waste oil that is not currently recycled. Of course, knowledge of the amount of unrecycled or illegally disposed oil would help in defining the extent of the problem. Neither the U.S. Department of Energy (DOE), EPA, nor any other organization should have to manage unrecycled, illegally disposed waste oil if its total volume is inconsequential. However, determining whether the volume of illegally disposed oil is $100 \times 10^{6} \mathrm{gal} / \mathrm{yr}$ or $400 \times 10^{6} \mathrm{gal} / \mathrm{yr}$ may be of limited value. The volumes of unrecovered oil are significant enough to warrant further research. Meaningful cost-benefit analyses can be derived from cxisting estimates of the waste oil generated.

- To set collection goals and assess the effectiveness of local used oil collection programs. Although important, this need may not be effectively met through a national program. A well-defined protocol (and funding to implement it) for estimating local waste oil generation volumes may better serve local waste oil collection coordinators. The American Petroleum Institute (API) (Stitzel 1992) has published some guidelines for estimating potential volumes of used oil in a local area, but their guidelines are not complete. Used oil collcctors also 
need to understand the motivations of their generators - what education or incentives are needed to maximize recycling, what other uses for used oil keep it from being recycled, etc.

- To define the used oil market and identify opportunities for companies or individuals to enter or expand the market. This need is important, but bigger questions currently overshadow it. The foremost of these is economics; the low price of oil influences the willingness of many companies to consider used oil recycling opportunities. According to representatives of primary refineries (which have the capacity to enter the used oil recycling business), the availability of used oil is currently not an issue. The potential profits of recycling used oil do not yet justify the risks and regulatory requirements associated with processing it. Another uncertainty involves used oil collection. Estimates of waste oil generated are only half the picture; this oil must be collected. The effectiveness of local oil collection programs has a significant impact on the availability of oil for recycle. Finally, if these data are critical to only a few industries, perhaps they are best generated by these industries. For example, the National Oil Recyclers Association (NORA) is currently surveying its members to define volumes and flows in the used oil management system.

- To define recycled content mandates for used oil. Although accurate estimates of the amount of used oil generated would help to define the maximum attainable level of recycled product contained in lubricating oil, at this time, more pressing questions must be answered. First, quality and testing issues related to re-refined oil must be addressed by the industry and those who set procurement requirements (e.g., military use specifications). Second, industry's capacity to produce re-refined oil is currently limited; recycled content mandates might need to be conservative, based on existing capacity and reasonable growth estimates. Prior to establishing mandates for recycled oil content, regulators need to more thoroughly define the term "recycled." For example, reprocessing used oil in primary refineries to produce products other than lubricating oil would need to be considered. Life-cycle environmental impacts of all recycling options, including burning for energy recovery, should also be assessed to ensure that recycled content mandates effectively protect the environment. Finally, on the basis of the legislative history of recycled oil content bills, passage of such a bill for lubricating oils is not likely in the near future.

On the basis of these arguments, we do not recommend that a comprehensive program to update waste oil generation factors on a national scale be undertaken at this time. Alternate avenues to obtaining the required data should be pursued. For example, these data could be derived from one of the following state or local programs: (1) developing software that allows state regulators to compile and assess data on the volumes of used oil generated, recycled, and disposed of in their states; and (2) developing and implementing a survey/focus group protocol 
that allows local used oil program coordinators to estimate the volume of used oil generated in their localities and assess the motivational needs of their communities to reach their maximum recycling potential.

A study to update the used oil generation factor for automotive crankcase applications may be of most value in supporting DIY used oil collection programs. This factor could be reliably obtained from the actual operating experience of car fleets. Such a study should not be undertaken independently by government; its success will depend on the cooperative participation of the surveyed facilities and industries.

\subsection{Waste Oil Challenges}

Stepping back from concerns over the accuracy of waste oil generation estimates, we can take a broader view of the waste oil issue by considering the disposition of all lubricating oil sold domestically, as depicted in Figure 2. Three challenges were identified from this comprehensive view.

- Recover used oil currently disposed of or misused;

- Identify source and loss reduction opportunities; and

- Develop infrastructure more consistent with a reuse hierarchy.

The volume of waste oil believed to be dumped, landfilled, incinerated, or misused ${ }^{3}$ is significant $-450 \times 10^{6} \mathrm{gal} / \mathrm{yr}$. Energy and environmental benefits will result from recovering and recycling this oil.

The largest portion $\left(1 \times 10^{9} \mathrm{gal} / \mathrm{yr}\right.$ or $\left.140 \times 10^{12} \mathrm{Btu} / \mathrm{yr}\right)$ of lubricating oil sold is considered unrecoverable. This portion includes oil burned, leaked, and otherwise consumed during use or not recovered with the bulk of the oil after use. Past studies have largely ignored the unrecoverable oil. We believe opportunities exist to recover some of this oil, or to reduce its volume through source and loss reduction.

3 The term "misuse" includes a variety of nonfuel applications, with an estimated volume of $110 \times 10^{6} \mathrm{gal} / \mathrm{yr}$. Some of these alternative uses may be acceptable forms of recycling and conserving virgin oil. However, many (such as applying used oil to kill weeds or to lubricate equipment) are potentially damaging to the environment, because the oil may eventually migrate to soil or water. Nontoxic oils (e.g., rapeseed) should be used for these applications. Because details regarding individual alternative applications are unknown, all of them have been labeled as "misuse" for this study. 


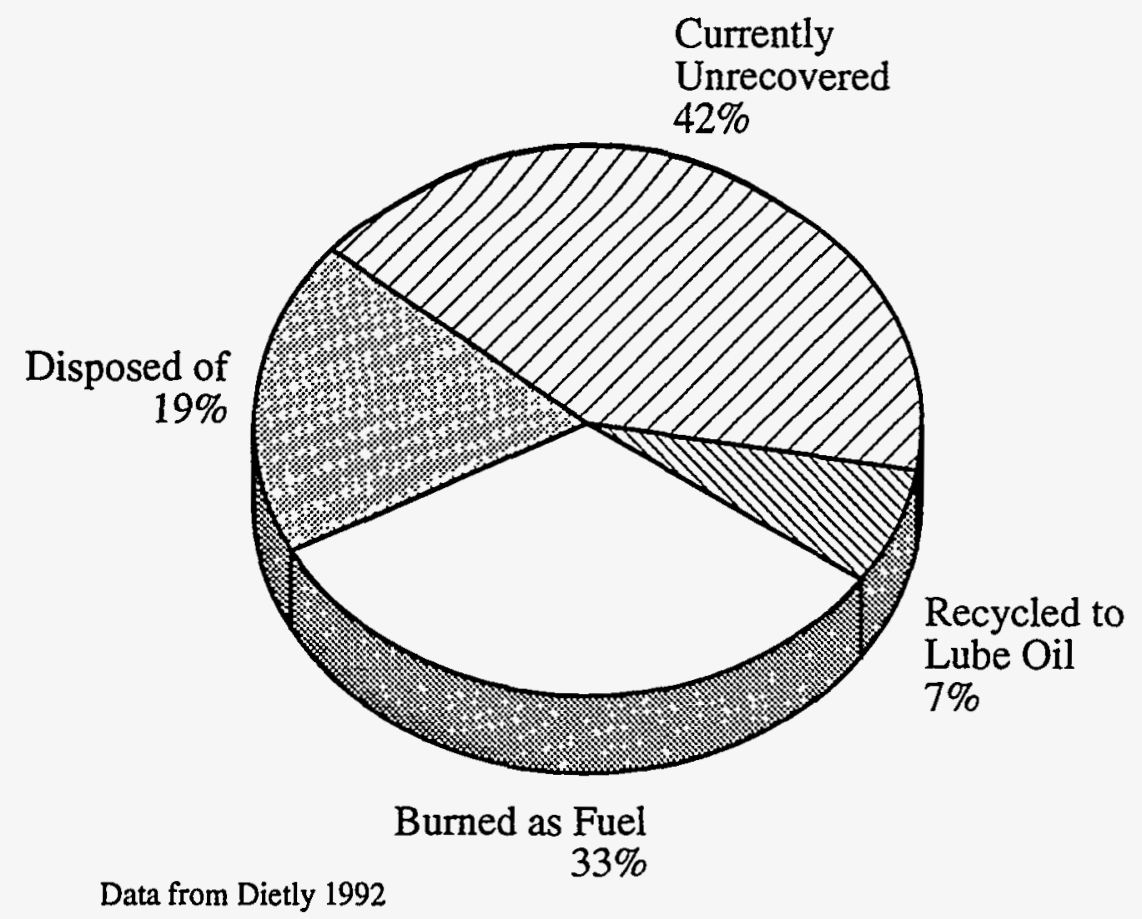

FIGURE 2 Disposition of Lubricating Oils Sold in the United States

Only a small percentage of waste oil is recycled (re-refined) to its original use. Energy savings could be realized through multiple-use cycles of re-refined oil. Reuse options should be promoted based on their energy, environmental, and economic impacts, consistent with a reuse hierarchy.

Potential energy savings associated with each of these challenges are presented in Figure 3. Background on the first challenge, increased recovery, is presented in Section 4, Waste Oil Collection. The remaining two challenges are discussed in Section 5, Waste Oil Reuse Options. 
16

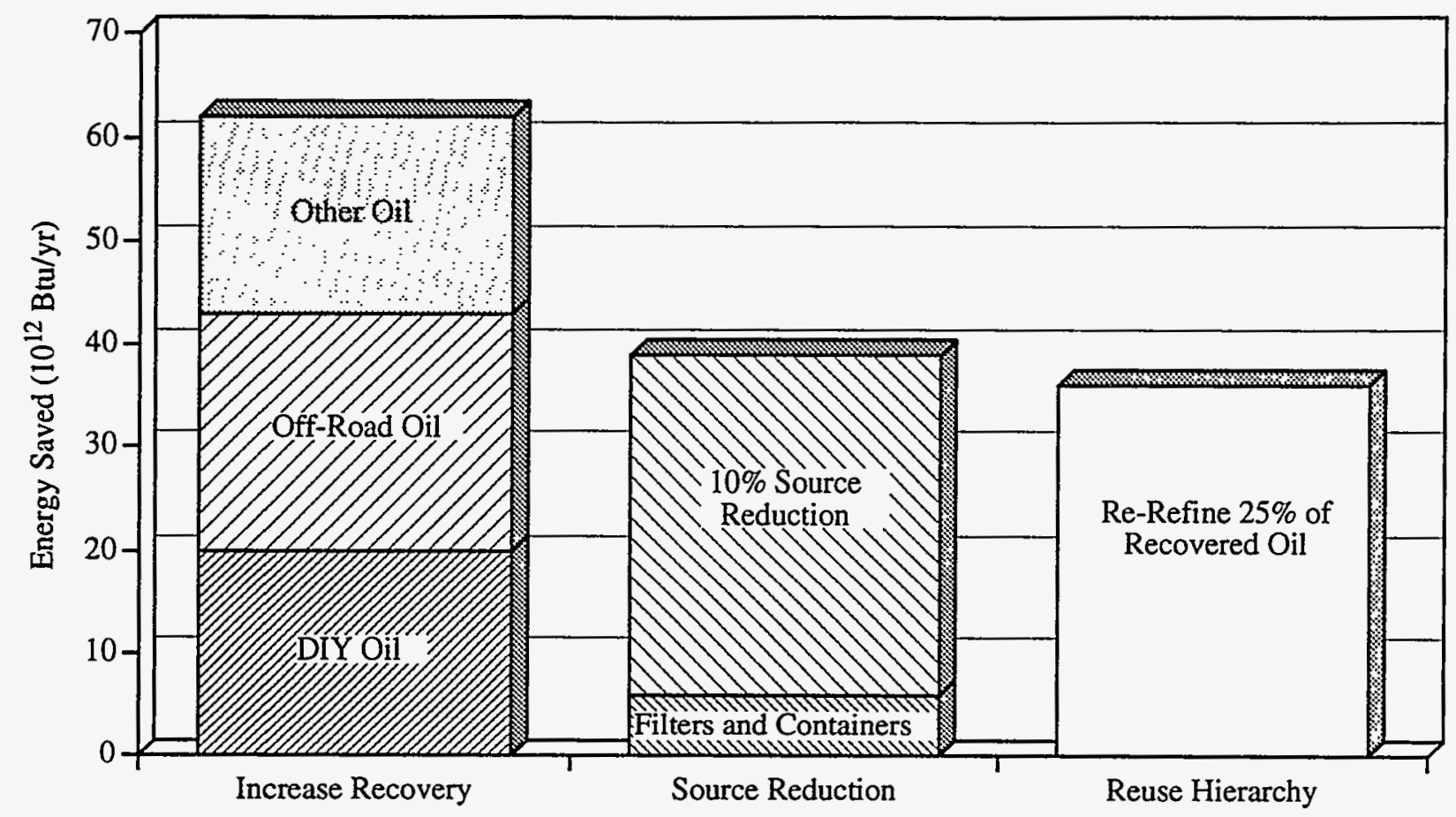

FIGURE 3 Potential Energy Savings of Meeting Waste Oil Challenges 


\section{Waste Oil Regulations and Incentives}

\subsection{Federal Regulations}

EPA promulgated management standards for used oil destined for recycling on September 10, 1992. These standards, which apply to all used oil handlers (i.e., generators, transporters, processors and re-refiners, marketers, and burners), have been adequatcly described and summarized elsewhere (Thompson Publishing Group 1992). They are designed to be protective of the environment without the need to regulate used oil as a hazardous waste. The most stringent standards apply to the processors and re-refiners because of the high volumes they handle and the historical mismanagement of used oil within this industry. Federal standards that can affect the reuse of waste oil are briefly described below:

- Classification of "on" and "off" specification used oil. Used oil is classified as off specification if it fails to meet the following criteria:

$\begin{array}{ll}\text { Arsenic } & 5 \text { parts per million (ppm) maximum } \\ \text { Cadmium } & 2 \mathrm{ppm} \text { maximum } \\ \text { Chromium } & 10 \mathrm{ppm} \text { maximum } \\ \text { Lead } & 100 \mathrm{ppm} \text { maximum } \\ \text { Flash Point } & 100^{\circ} \mathrm{F} \text { minimum } \\ \text { Total Halogens } & 4,000 \mathrm{ppm} \text { maximum }\end{array}$

Burning of off-specification used oil is restricted to industrial furnaces (e.g., cement kilns, lime kilns, aggregate kilns, phosphate kilns, coke ovens, and blast furnaces), industrial boilers, utility boilers, and incinerators. These sites must be registered with EPA to burn off-specification oil. Used oil can also be blended to meet specification levels, with two exceptions: (1) if it is presumed to be mixed with chlorinated hazardous waste, or (2) if it contains a quantifiable amount of polychlorinated biphenyls (PCBs). Generators or collectors of DIY oil can also burn off-specification used oil on-site in space heaters with a maximum capacity of $500,000 \mathrm{Btu} / \mathrm{hr}$.

- Rebuttable presumption of mixing. Used oil that contains more than $1,000 \mathrm{ppm}$ total halogens is presumed to be mixed with chlorinated hazardous waste. Unless this presumption can be rebutted, the used oil must be managed in accordance with Resource Conservation and Recovery Act (RCRA) hazardous waste regulations. The reuse of this oil is restricted to businesses certified to manage hazardous wastes. 
- Prohibition of use as a dust suppressant. Use of waste oil to oil roads or suppress dust is prohibited, although individual states can petition for an exemption to this prohibition.

- Standards for disposal. Once a decision is made to dispose of used oil, it must be tested for hazardous characteristics. Used oil that exhibits one or more of the characteristics of hazardous waste must be manifested and transported to a regulated Subtitle $C$ disposal facility. Existing industrial and municipal waste landfill regulations are imposed for disposal of nonhazardous waste oil.

- $\quad P C B$-contaminated used oil. Used oil containing detectable levels of PCBs is regulated under the Toxic Substances Control Act (TSCA) and is not subject to the used oil management standards. Oils with PCB concentrations of $50 \mathrm{ppm}$ or greater must be disposed of in accordance with TSCA regulations only at qualified and permitted incinerators, high-efficiency boilers, or chemical waste landfills.

Additional regulations under consideration by EPA that could impact used oil recycling include the following: (1) lowering the 100-ppm maximum lead specification for used oil burned as fuel; (2) implementing a market-based incentive system (recycling ratio or deposit/refund system) to increase used oil recycling; (3) adopting closure requirements for used oil handling sites; (4) listing residuals from used oil processing and re-refining as hazardous waste; and (5) eliminating the distinction between the halogen limitation for the rebuttable presumption of mixing and the limitation for specification fuels (Thompson Publishing Group 1992).

The federal government's oil management standards are designed to minimize contamination of used oil with other potentially toxic materials. Consequently, some provisions of the current law (e.g., the hazardous waste mixture rules) can restrict reuse of oil that has been contaminated, requiring it to be disposed of instead of recycled. Reprocessors or re-refiners that have the technology to safely recycle contaminated oil are constrained by current regulations. An account should be made of the volume of contaminated oil that must be disposed of annually because of these regulations. If this volume is significant, modifications to the current regulations may be warranted to facilitate safe recycling of this oil without eliminating the penalties for contaminating used oil.

\subsection{Federal Incentives}

Incentives proposed by EPA to promote the recovery and recycle of used oil from DIY oil changers include the following (40 CFR Parts 261 and 266):

- Regulatory relief to establishments that collect DIY oil; 
- Requirement that used oil generators or lubricating oil retailers accept used oil from DIY oil changers;

- Requirement that used oil recyclers/re-refiners initiate community-based DIY

- collection programs;

- Recycling target (mandatory recycling ratio) for lubricating oil manufacturers or importers;

- Used oil credit system in which lubricating oil manufacturers could meet recycling targets by recycling used oil themselves or purchasing recycling credits at market-determined prices; and

- Deposit/refund system for used oil.

EPA is also adopting measures to increase government demand for products that contain re-refined oil. The development of markets for re-refined oil is a critical need for the industry. On June 30, 1988, EPA issued guidelines for the procurement of re-refined lubricating oil (40 CFR Part 252). Executive Order 12873, published on October 20, 1993, further reinforced the requirement that federal agencies implement these procurement guidelines.

EPA expects federal procurement of re-refined oils to have a significant "ripple" effect on the volume of re-refined oil purchased nationwide. A current barrier to increased purchases of re-refined oil by state, local, and private organizations is the limited availability of products that meet applicable military specifications. Re-refined oil suppliers have been reluctant to assume the high costs of qualifying their products to meet these specifications because, historically, no sales have resulted from these efforts. Increased federal sales may provide the incentive for more re-refined oil suppliers to qualify their products to meet military standards.

The federal government has also field tested re-refined oils. The U.S. Postal Service's demonstration program is perhaps the most successful to date. The Postal Service purchases re-refined oils marketed by Safety-Kleen and Evergreen for use at its regional vehicle maintenance facilities (if the products are locally available).

The General Services Administration (GSA), which owns and operates most of the government's civilian fleet, has identified the following barriers to increased use of re-rcfined oils: product quality concerns, vehicle warranty constraints, lack of availability of products at local service stations where vehicles are maintained, and possible impact on the resale value of the vehicle if re-refined oil is used (Arnold 1994). These same concerns are shared by private citizens in their decisions to purchase re-refined oils. If the government, in its procurcment process, can effectively address these issues, increased sales of recycled content oils to other sectors are expected. 
Ford Motor Company and General Motors issued revised position papers on the use of re-refined oil in September and December 1994, respectively. In their statements, these companies endorsed the use of re-refined motor oils that meet API certification requirements (identified in the marketplace with the API "Starburst" certification mark) and that undergo strict manufacturing controls and testing. As a result of the revised positions of these automobile manufacturers, GSA issued a memorandum to its federal fleet managers in February 1995 encouraging the purchase of re-refined oil that meets API standards, is the appropriate grade and viscosity for the vehicles serviced, and is priced at or below the cost of a comparable virgin oil product.

Very recent progress has been made in the institutional acceptance of re-refined motor oils. However, increased customer satisfaction with re-refined motor oils will be required to expand the markets for these products, particularly into the private sector.

\subsection{State Regulations}

ANL reviewed current and proposed state regulations and incentives related to used oil to identify any regulatory trends or initiatives that might affect the future reuse of waste oils. This information is presented in tabular form in Appendix A.

All states regulate used oil in some manner, for the most part in accordance with EPA's used oil management standards. Most states do not regulate used oil as a hazardous waste if it is destined for recycling or burned for energy recovery. Used oil slated for disposal in these states is regulated as a hazardous waste if it exhibits a hazardous characteristic or has been mixed with a listed hazardous waste. States also have laws and permitting requirements governing closure of used oil handling sites, underground storage tanks, used oil transport, and burning of used oil.

A limited number of states have enacted regulations that are stricter than the EPA used oil management standards. California, Massachusetts, New Hampshire, New Jersey, and Rhode Island regulate used oil as a hazardous waste regardless of its intended disposition. In these states, registration/permitting, recordkeeping, and reporting requirements are more stringent than those specified by EPA. Some states that do not regulate used oil as a hazardous waste still maintain permitting, recordkeeping, and reporting requirements for used oil handlers beyond those specified in the EPA used oil management standards.

Application of used oil as road oil, dust suppressant, or herbicide is prohibited in most states. Free liquid disposal in solid waste landfills is prohibited in the majority of states. Several states ban any landfill disposal of used oil, and some require that used oil be collected only at registered sites. Discharge of waste oil to sewers, drainage systems, surface or groundwater, watercourses, or marine waters is prohibited in many states. Used oil filter disposal has recently been banned or restricted in a few states. 
Clearly, disposal of used oil on land or water is not an acceptable alternative. Bans on the disposal of used oil filters are relatively recent, but foretell a future commercial opportunity for the recovery and recycle of this resource.

Some specific state requirements that extend beyond EPA used oil management standards are listed below:

- Burning of used oil in residential boilers is prohibited in Connecticut;

- Motor oil retailers are required to post the locations of the nearest collection sites in Iowa, Kansas, Kentucky, Maryland, Minnesota, Montana, Oklahoma, Rhode Island, and Virginia;

- Motor oil retailers and service stations are required to collect DIY oil at no charge in New York, Massachusetts, and Wisconsin;

- Stricter standards for composition of "pure" or "on-specification" used oils have been established in California, Missouri, New Hampshire, and Pennsylvania;

- Stringent requirements, regulations, and fees designed to discourage burning of used oil as fuel have been promulgated in Vermont and Arizona;

- Sale of absorbent-based kits for DIY oil maintenance is prohibited in Washington;

- Motor oil in New Jersey must be clearly labeled as containing recyclable material;

- Landfill disposal of used oil filters has been banned in Texas, Minnesota, and Rhode Island; and

- Burning of used oil in space heaters during the months of June, July, and August is prohibited in Massachusetts.

The following aggressive state laws might signal future changes in used oil handling standards: (1) lower lead content for on-specification oil (e.g., in California, the standard of purity is $50 \mathrm{ppm}$ maximum lead); (2) lower halogen content for on-specification oil (e.g., in California, the standard of purity is $1,000 \mathrm{ppm}$ maximum total halogens); (3) restrictions on burning of used oils, particularly in space heaters; and (4) restrictions on the disposal of used oil filters and other oil-contaminated materials. 


\subsection{State Incentives}

Several states have enacted laws designed to establish used oil collection programs and to promote its recycling. Some program components are listed below:

- Public education;

- Information and hotlines on local used oil collection, transportation, and recycling options;

- Government-owned and -operated collection sites;

- Subsidies for companies to purchase used oil burners;

- Grants for purchase of collection site storage tanks;

- Curbside collection programs;

- DrY collection goals incorporated in local waste management plans;

- Reimbursements of the costs for proper disposal of hazardous used oil contaminated by DIY contributions;

- Grants to provide containers and supplies for DIY used oil collection;

- Cash incentives per gallon of oil recycled; and

- State purchasing preferences and mandates for products that contain rc-refined oil.

In some states, these programs are funded by a sales tax on lubricating oils, as advocated by API in its model legislation proposals. 


\section{Waste Oil Collection}

Waste oil is generated by an estimated 700,000 industrial facilities and 50 million DIY households. Collection and transportation of used oil are, therefore, critical factors in the infrastructure of the used oil management system. The industry that has evolved to meet these needs is characteristically regional. To be effective, national initiatives must incorporate regional issues into their design.

The 1991 Clayton study concluded that the majority of industrial waste oil generators manage their waste oil responsibly. DIY and off-road generators (farming, mining, and construction), on the other hand, are credited with illegally dumping (or misusing) 140 and $170 \times 10^{6} \mathrm{gal} / \mathrm{yr}$ of used oil, respectively. Initiatives to increase the recovery of waste oil must target these two sectors. Several local governments and private enterprises have implemented successful used oil collection programs to recover this oil. One objective of this study was to survey model programs to identify cost-effective program components and common program needs.

The following conclusions evolved from these surveys:

- The DIY used oil collection problem has been addressed by many initiatives, especially in non-rural areas. Only a few programs were identified, however, for collection of used oil generated by off-road sources.

- Many program components to enhance the effectiveness of DIY used oil collection programs were identified; however, quantitative data required to evaluate the cost effectiveness of different programs or components are not available or are inadequate.

- A large portion of the DIY oil changers do not appear to be motivated by the environmental or energy benefits of recycling. Researchers need to determine how to motivate DIYs to recycle their used oil.

\subsection{Survey Scope}

API has been very active in promoting used oil recycling. Its initiatives include model legislation for state used oil collection programs and guidelines for setting up curbside or drop-off used oil collection programs. Its well-considered proposed program components are highlighted in our summary. Several members of API also sponsor voluntary DIY used oil collection programs. These companies, including Amoco, Mobil, Pennzoil, Valvoline, Quaker State, Chevron, and Texaco, were contacted to contribute to this study. 
The following states have sponsored used oil collection programs with varying degrees of funding and public promotion: Alabama, California, Connecticut, Delaware, Washington D.C., Florida, Georgia, Iowa, Maine, Maryland, Minnesota, New Jersey, New York, Oregon, Pennsylvania, Rhode Island, South Carolina, South Dakota, Tennessee, Texas, Vermont, Washington, and Wisconsin. Representatives from each of these states were contacted to discuss their programs. We also contacted representatives from several other states to discuss used "oil regulation and collection issues. All representatives were asked to identify and describe model or unique used oil collection or recycling programs in their states. Those responsible for developing or implementing many of these programs were also interviewed.

A full listing of individuals (with their affiliations) who contributed to this portion of the study is provided in Appendix B. Input was also obtained from the following literature sources: Gottleib 1981; EPA 1989; Nolan, Harris, and Cavanaugh 1990; Stitzel 1992; Swager, Al-Basha, and Kraft 1993.

\subsection{Needs and Opportunities Identified}

The used oil program coordinators contacted for this study offered many suggestions to increase the recovery and recycle of used oil. Their ideas are listed below:

- Implement a comprehensive, national used oil recovery and recycle plan that is impervious to individual state political and legislative environments;

- Expand public education and awareness programs;

- Determine how to motivate DIY oil changers to recycle their used oil;

- Improve the accuracy of the estimates of used oil generated in local areas;

- Increase the number of sites where DIY oil changers can return used oil free of charge;

- Increase the availability of curbside used oil collection programs, particularly in metropolitan areas, and determine the cost effectiveness of this collection option;

- Develop pilot programs for cost-effective used oil collection in rural areas;

- Subsidize transportation of used oil from collection sites in rural areas; 
- Develop an inexpensive, simple "litmus" test to identify contaminated oil brought to collection sites by DIY oil changers;

- Establish procedures, support services, or regulatory relief for handling orphan oil (used oil left or disposed of improperly at private businesses);

- Develop national procedures or standards for safe operation of indoor used oil collection tanks to replace local fire marshal restrictions;

- Extend the service station dealer exemption for Comprehensive Environmental Response, Compensation, and Liability Act (CERCLA) off-site liability to retailers who collect used oil from DIY oil changers but otherwise do not service automobiles;

- Establish recovery and recycle programs for oil filters, oil-contaminated containers, adsorbents and rags, and other automobile wastes (e.g., antifreeze, brake fluid);

- Determine environmental impacts, particularly lead emissions, of burning used oil in space heaters and industrial boilers;

- Identify environmentally acceptable alternative uses for used oil, particularly off-specification oil;

- Increase the amount of used oil re-refined to lubricating oil and reprocessed in primary refineries;

- Alter public perception that re-refined motor oil is inferior to virgin motor oil;

- Determine the environmental impact of used oil disposed of on land or into sewers;

- Determine the difference in volumes of illegally disposed used oil in states where used oil is regulated as a hazardous waste versus those where it is not;

- Determine the impact of burning used oil in asphalt plants on the performance of roads where the asphalt has been applied (this application is currently 
banned in South Dakota because of concern that road surfaces may be damaged by residuals left by used oils in the asphalt); and

- Determine the environmental impacts of burning used oil as fuel in the maple sugar industry (Wisconsin interest).

\subsection{Components of DIY Used Oil Collection Programs}

From the literature and through discussions with program coordinators, ANL identified several components that enhance the effectiveness of DIY used oil collection programs: sustained funding, DIY participation, limits on liability, technical assistance to collectors, and assessment. Each of these components is discussed below.

\subsubsection{Sustained Funding}

Funding is required for start-up costs (such as purchase and installation of collection tanks); program coordination, management, and technical assistance; public education; and in some cases, transportation of used oil to the recycler and/or proper disposal of DIYcontaminated used oil. Costs for the program beyond initial start-up costs are likely to decline with time and could be controlled through training and improved practices at oil collection sites. An established program that does not receive sustained funding, however, has little chance of remaining effective.

Funding sources are often controversial. Many states are currently struggling to balance their budgets in an environment of unfunded federal mandates and social needs related to education, crime, health care, and other social services. Several states (California, Florida, Iowa, Maryland, Minnesota, Rhode Island, Tennessee, Texas, and Vermont) have legislated grants to allow municipalities to subsidize collection site start-up costs. In many of these states, though, the grant offerings have expired or their initial funding has been depleted.

To supplement dwindling resources, Maryland has negotiated with used oil haulcrs to pay for used oil collected in the state, but these payments supply only a fraction of the funds needed to support the state's recycling program. Iowa funds its collection day and grant programs through household hazardous product retailer permit fees and state solid waste landfill tipping fees. Florida obtains partial funding for its program through used oil collector, transporter, and recycler registration fees. Hawaii appropriates monies from its crude oil tax to support used oil recycling programs. Other states fund their programs through general appropriations.

API model legislation suggests a sunset tax on motor oil sales ( $\$ .02 /$ quart) dedicated to funding used oil collection programs. This effective funding alternative has been implemented or 
is being considered in several states. Texas, one of the first states to implement this legislation, appropriated $\$ 10$ million of these revenues to other programs last year. The state's used oil collection program was still adequately funded, but the experience highlights a disadvantage of a state-legislated tax system as the source of program funding.

A few of the program coordinators interviewed by ANL advocated a life-cycle responsibility approach to funding used oil collection programs - placing the burden of funding on the lubricating oil manufacturers. The mechanism for mandating such funding is not clear. In Massachusetts and New York, motor oil retailers are required to accept DIY oil for recycling. Under this program, the retailer, not the lubricating oil manufacturer, is shouldering the cost of used oil collection.

Several lubricating oil manufacturers, quick lube change services, and auto parts retailers are voluntarily collecting DIY oil and/or contributing funds to public education efforts. The Metro Kansas City Used Motor Oil Collection Program is an excellent example of private/public partnership and funding. A working group comprising representatives from private industry and the public sector developed the program, including guidelines for operation of collection sites. They established 143 voluntary private-sector collection sites in the first year. Private industries are also contributing funds for public education campaigns in support of the program.

The ability and commitment of all communities to recruit and sustain voluntary contributions from private industry is uncertain, however. Historically, private-sector involvement in used oil collection has been greatest when the value of crude oil, and consequently the markets for and value of used oil, have been highest. Reprocessed or blended used oils compete for market share with industrial fuel oils; pricing of these fuels is closely linked to crude oil pricing. As the cost of these fuels decreases, the selling price for used oil, which is typically discounted by about $10 \%$ relative to fuel oils, also decreases. To cover collection and processing costs, used oil marketers may charge generators to collect and transport their oils. This added cost discourages private businesses from collecting used oil from DIY used oil changers, especially from those who are not otherwise their customers. Many service stations that collected DrY oil during periods of high crude oil pricing (post-oil embargo, pre-1985) discontinued their programs once oil prices plummeted.

The "polluter pays" concept is typically directed at industry. However, in the case of used oil, the polluter is the DIY oil changer who dumps the oil. According to most references, the majority of service stations and quick lube oil change establishments currently manage the used oil they generate in a responsible fashion. Consumers who employ these services are paying to have their used oil responsibly managed; DIY oil changers are not. In fact, charging a fee to accept their used oil discourages DIY oil changers from recycling.

The polluter pays concept can be invoked by an environmental tax/refund program. California has implemented such a program. However, all motor oils are taxed, not just those sold to DIY oil changers. Also, the tax (4\&/qt), while adequate for program funding, may not be high enough to impact DIY behavior. 
A highly visible environmental tax (25-50ф/qt) at the point of motor oil sale to DIY oil changers could provide the following benefits: (1) sustained funding source for state and/or local oil collection programs; (2) coverage of collection and transportation costs associated with used oil recycling, particularly when crude oil prices are low and/or for remote areas; (3) sizeable refund incentive (e.g., \$1/gal) on oil returned for recycle by DIY oil changers; (4) increase in public awareness by communicating the environmental cost of improper used oil disposal; and (5) mechanism for tracking DIY oil consumption and used oil generation.

Arguments against an environmental tax/refund system often cite the increased paperwork; increased government intervention; and hassle associated with taxes, deposits, or refunds at the retail level. Some opponents are concerned that the DIY oil changers will contaminate or dilute used oil to increase their refunds. Although these concerns are legitimate, they can be resolved by designing and implementing appropriate practices, procedures, and support systems for the program.

Core charges invoked at auto parts stores for specific items like new batteries, alternators, generators, and other parts are similar in concept to an environmental tax/refund system. The consumer pays the core charge at the point of sale of an item. This fee is typically refunded when the consumer retums the item being replaced. For oil, a core charge could be assessed on the oil or on an "oil change package" that would include a reuseable container for draining and returning the used oil and filter to the retailer. The retailer would recover the costs for providing this collection alternative by retaining a specified fraction of the core charge. The consumers would then receive a partial refund of the core charges when they return used oil for recycling.

By using the core charge system, retailers would avoid the administrative details and costs associated with tax/refund systems; but the system would not provide funds for public used oil collection programs (e.g., curbside collection, public education). If properly structured (i.e., if all retailers participate and the refund amount is an adequate incentive for recycling), a used oil collection infrastructure consisting of motor oil retailers funded by core charges could preclude the need for public-sponsored programs.

\subsubsection{DIY Participation}

The contributors to this study identified three requirements to ensure DIY participation in used oil collection programs: (1) collection sites (drop-off or curbside) must be availablc; (2) DIY oil changers must know the locations, hours of operation, and procedures for using the collection sites; and (3) DIYs must want to use the collection sites. These requirements cover three concepts in used oil collection: convenience, public education, and motivation.

Convenience. Decisions regarding the location and number of collection sitcs and selection of drop-off or curbside programs are best made locally - with considcration of demographics and existing solid waste collection infrastructures. Sevcral documents (EPA 1989; Hegberg et al. 1991; Stitzel 1992) provide guidelines for thesc decisions. 
Curbside collection appears to be the most convenient option available to the DIY oil changer. Curbside service is often advocated as the preferred collection program for metropolitan areas. The availability of curbside used oil collection does not, however, ensure high oil recovery rates. For example, in Oregon, over 100 municipalities are served by curbside used motor oil collection programs; 301,000 gal of used oil were collected curbside in 1992. Drop-off collection sites are available in communities not provided with curbside pickup service. A total of 113 known drop-off sites are located in Oregon. The combined curbside and drop-off used oil collected in 1992 was 489,000 gal - only $20 \%$ of the estimated 2,400,000 gal of used oil generated annually by DIY oil changers in Oregon. Oregon's program coordinator is very interested in understanding what DIY oil changers are currently doing with their used oil (do they have alternative uses for it?) and what will motivate them to recycle it.

Information obtained from this study suggests that, for drop-off programs, a distance beyond 10 miles discourages DIY oil changers from recycling their used oil. The many potential locations for drop-off collection sites include the following: solid waste transfer stations, public fleet service stations, auto parts retail stores, service stations, quick lube establishments, landfills, and recycling centers. One collection tank for a population of 10,000 is suggested.

Collection at service stations, quick lube shops, and fleet maintenance facilities already equipped with used oil tanks offers the following advantages: (1) employees of these establishments should be experienced in handling used oil, (2) arrangements for collection and transport of used oil from the sites to a recycler should already be established, and (3) existing used oil tanks could be used to store DIY oil (however, mixing DIY oil with oil generated on-site can complicate exemptions for DIY-contaminated oil). New Jersey legislation requires that these establishments collect used oil. The voluntary collection programs sponsored by industry are, in many cases, dependent on the participation of these establishments. Participation of private businesses in voluntary collection programs has historically varied with the price of oil and the regulatory climate. Collection sites that do not consistently accept oil from year to year can discourage participation by DIY oil changers in the program.

In Rhode Island, high used oil recovery rates have been recorded in rural areas where the used oil collection site is at the local transfer station or landfill. Three reasons for the success of this program are forwarded: (1) all residents must pass through these stations to drop off their trash, so they do not need to make separate trips to recycle their used oil; (2) residents are educated about the program by observations made during their visits; and (3) the percentage of DIY oil changers is higher in rural communities, so the volume of oil is greater, yielding higher recovery rate estimates (an average of $38 \%$ in ten communities with the highest recovery rates).

Locating drop-off sites at places of employment is another interesting alternativc, particularly in rural areas. Amana Refrigeration Inc., in Amana, Iowa, sponsors an unstaffed, sheltered drive-in facility for drop-off of recyclables, including used oil, from its cmployees and the public. Since the program was established in 1990, Amana has collected, without incident, $1,500,2,070$, and 3,210 gallons of used oil in 1991, 1992, and 1993, respectively. 
Other contributors to this study suggested that having used oil drop-off sites at the same location as household hazardous waste collection centers would be advantageous. They believe DIY oil changers are less likely to contaminate their used oil with hazardous substances if proper disposal options for these materials are available. Iowa sponsors Household Hazardous Materials Toxic Cleanup Days to provide its residents an opportunity to properly dispose of these materials. Over 54,000 gallons of waste oil have been collected in 63 of these events held in different Iowa counties from 1988-1993.

Collection sites at the point of sale of motor oil seem to be particularly convenient to the DrY oil changer. In fact, the combination of motor oil sales and used oil collection offers one option to address many issues related to used oil recycling by using a systems approach in concert with an environmental tax/refund or core charge program. For example, consumers could be supplied with specially designed, re-usable containers (e.g., clear, sealable oil drain pans with an enclosed insert slot for filters to drain into the pan) for the return of their used oil and filters - maximizing the recovery of oil, minimizing the generation of oil-contaminated containers, and eliminating spillage from unsuitable containers. Shell Oil Company and Clark Technology Systems Inc. are currently marketing oil change systems (the Oil Bank for commercial and industrial applications and the Oil Bank Briefcase for DIY applications) that address some of the technology needs for this suggested approach.

Growmark, in Bloomington, Illinois, has developed a market plan that includes used oil collection guidelines for its local farm cooperatives, which also market lubricating oils. By providing a used oil collection service to these rural communities, the cooperatives expect increased business. Many states encourage retailers to collect used oil from DIY oil changers. New York and New Jersey require that motor oil retailers accept used oil from their customers. Such mandates, without support systems, can be a hardship for retailers.

Valvoline Environmental Services assists in the installation and operation of DIY used oil collection tanks at retail outlets. Valvoline employees found that retailers with service bays and auto parts shops, where the employees are experienced in handling oily materials, are good candidates for DIY collection sites. At convenience stores or retailers without service bays, on the other hand, they encounter logistical constraints in collecting DIY oil: not enough floor space, inconvenient location of tanks to avoid indoor transport of oil by customers or employees, and not enough staff to deliver the timely service expected by customers.

Other issues related to convenience include the following: for curbside service, provision of special containers for residents and frequency of pickup; and for dropoff, hours of opcration of the collection sites and unattended versus attended dropoff.

Public Education. Beyond convenience, DIY oil changers must be educated on the locations and requirements for collection of their used oil. Public education programs have been sponsored by several states: Alabama's Project Rose, Florida's Used Oil Management Program, Maryland's Used Oil Recycling Program, Georgia's PETRO project, and California Uscd Oil Recycling Fund. No data have been collected on the cost effectiveness of any pilot or existing 
public education program, so no model program can be defined. However, some common and unique components of the programs surveyed include the following:

- Hotlines providing information on the location, operating hours, and procedures for used oil collection sites.

- Posted signs at motor oil retailers stating the importance of recycling used oil and the location of the nearest collection site.

- Print and billboard advertisements.

- Public service announcements on radio and public and cable television. For example, East Central Iowa Council of Governments prepared an awardwinning public service announcement showing oil being dumped into a sewer and then splashed back at the dumper as an ugly blob of black oil with the message, "When you discard something improperly, it may come back to you."

- Informational packets and brochures, provided at the point of motor oil sale, and to driver education programs, elementary schools, and the general public.

- Public education efforts, such as Florida's curriculum package (DIY-800), which included a curriculum notebook, educational game, videotape, oil lifecycle poster, and oil sample.

- Targeted notices such as the "OOPS" tags for contaminated oil set out in Huntsville, Alabama's, curbside collection program; door hangers distributed in neighborhoods in Sunnyvale, California, when oil is detected in the sewer system; and calls made to residents by solid waste haulers when oil is observed in their garbage.

- Program kick-off day events such as the Metro Kansas City Used Motor Oil Collection Program, which provided free oil catch pans to the DIY oil changers who returned their oil on kick-off day; over 2,000 pans were given out within the first few hours.

- Storm sewer labelling to increase residents' awareness that materials dumped directly into sewers or carried into sewers by rain go directly into local streams or rivers (e.g., "Million Points of Blight" program developed by the Center for Marine Conservation). 
Public promotion campaigns and materials development can be costly, particularly television commercials. For example, Amoco representatives estimate that the company spent \$3-4 million to initially promote its voluntary collection program. In Florida, \$1.5 million was appropriated and spent on a public awareness and education program. Promotional spots can also backfire if they are aired before facilities are made available for used oil collection.

Motivation. Finally, DIY participation in used oil collection programs depends on motivation. Input from program coordinators reveals that not all DIY oil changers are motivated to recycle their used oil for environmental or energy conservation reasons. States with widespread public education programs still find that a significant portion of DIY oil changers do not participate in their communities' used oil collection programs.

In Columbia, South Carolina, officials are conducting a pilot billboard campaign emphasizing that dumping used oil is a crime. Billboards read "Dumping used oil in South Carolina is not only rude, crude, and socially unacceptable... IT IS AGAINST THE LAW!" Calls from this area to the recycling program hotline increased after the billboards were posted, suggesting that not breaking the law may be one motivator for many DIY oil changers.

California is sponsoring sociological research into the problem of DIY motivation. The state has contracted the research to a public relations firm, Deen \& Black. The first phase of the study - a survey of DIYs to establish their characteristics and demographics - is complete. The second phase is currently being developed to determine how to motivate DIY oil changers to recycle their oil. Researchers expect to complete the study in one to two years.

\subsubsection{Limits on Liability}

Used oil collectors have two basic liability concerns: (1) the cradle-to-grave responsibility of a generator for hazardous wastes, and (2) the disposal costs for contaminated oil. API and many other associations and businesses have lobbied extensively to prevent used oil from being classified as a hazardous waste. They cite the threat of this classification as the single greatest factor discouraging private businesses from collecting used oil from DIY oil changers. In the end, only well-considered legislation (regardless of the classification of used oil) can protect used oil collectors from these liabilities. Therefore, we will not discuss the classification of used oil in this report.

Used oil can be contaminated by a variety of materials such as antifreeze, brake fluid, carburetor cleaners, gasoline, paint, and water. Contaminants containing chlorine (brake fluid and some solvents) can be especially insidious. As an example, less than 8 oz of chlorinated solvent will cause the contents of a 55-gal drum of used oil to exceed the rebuttable presumption level of $1,000 \mathrm{ppm}$ halogens, requiring the contents to be disposed of as a hazardous waste unless the source of halogens is adequately documented. This disposal is costly to the used oil collcctor. 
Educating the public and used oil collection staff in proper procedures is important to minimizing occurrences of contaminated oil. However, convenient options should be provided for DIY oil changers to return their used oil, even if it is contaminated. Otherwise, this oil may be improperly disposed of or misused. Current regulations provide the opportunity for collection site operators to accept contaminated used oil from DIY oil changers and recycle it without additional cost. Because RCRA provides no authority to regulate households, DIY-contaminated oil is not classified as a hazardous waste. So, with supporting documentation, used oil containing high halogen levels that can be tracked back to DIY contamination can be processed like any other used oil.

To date, however, reported occurrences of DIY contamination have been infrequent. The API model legislation recommends, and some states (California, Maryland, South Carolina, Tennessee, Texas, and Vermont) provide subsidies to registered collection sites for the proper disposal of DIY-contaminated oil. By requiring registration, the states have some control in ensuring that operating practices designed to minimize contamination are employed at the collection sites.

Some companies that sponsor voluntary collection programs also provide financial or technical assistance for the disposal of used oil contaminated by DIY oil changers. Mobil agrees to pay the costs for disposal of contaminated oil from participating private businesses; since initiation of its recycling program in 1990, however, the company has not had any cases of contaminated oil. Amoco shares the cost of contaminated oil disposal with its participating stations.

Other programs (Amoco, California) supply halogen testers to collection sites. If properly calibrated and used, these instruments can eliminate the threat of chlorine-contaminated loads. Because the presence of water, antifreeze, and gasoline can often be detected visually, several programs (particularly curbside collection programs) require that oil be returned in transparent containers. Proper use of halogen testers and visual inspection, however, requires time and effort from the collection site employees. For service stations and retailers whose primary business is not collecting oil, careful checking of the oil prior to acceptance may not be realistic during busy times with high return traffic. Several coordinators suggested the need to develop a simpler test to detect contamination in used oil.

In planning the used oil collection program in Kansas City, Missouri, concerns about contaminated oil were an initial obstacle. The planners resolved these concerns by establishing the following strict practices for collection:

- DIY used oil tanks must be installed inside, with access by the general public restricted;

- DIY oil should be stored in a designated tank, separate from used oil generated on the site; 
- Oil is collected only during normal operating hours of the participating establishments;

- The collectors log all transactions, and the DIY oil changers are requested to sign the log sheets confirming that their oil has not been mixed with any other substance;

- Oil is accepted only if it is returned in a clean, leak-proof container that has never contained a toxic substance;

- All oil is visually inspected and halogen tested prior to acceptance;

- Contaminated oil is returned to the customer with a rejection sticker explaining how to properly dispose of it; and

- Only staff are allowed to pour collected oil into the used oil tanks.

Measures adopted to avoid collection of contaminated oil may limit the liabilities of the collector, but may not be protective of the environment if the alternative is for DIY oil changers to improperly dispose their contaminated oil. As suggested previously, adequate recordkeeping may be the preferred alternative; with supporting documentation, used oil contaminated by DIY oil changers can be reprocessed for higher value markets than if it must be handled as a hazardous waste. Some DIY oil changers, however, may consider signing a log sheet and talking to collection staff to be deterrents to returning their used oil. These conflicting factors must be weighed in any procedural decisions.

Used oil collectors can also limit their liabilities by ensuring that they contract with only reputable, qualified, and properly licensed used oil transporters to remove oil from their sites. Small municipalities and private businesses are unlikely to have the resources to conduct an environmental audit of the used oil transporters and recyclers they employ. However, this service could be provided by the sponsoring company (as is done by Pennzoil and Quaker State) or a government agency. A universally accessible database on the environmental audit status of used oil transporters and recyclers would be a valuable tool for used oil collectors.

\subsubsection{Technical Assistance for Collectors}

The success of a used oil collection program also depends on the participation of the collectors, who require training and assistance to properly manage the oil they collect. Technical assistance is appropriate in the following areas: (1) selection, siting, and installation of used oil collection tanks; (2) procedures for accepting used oil from DIY oil changers and handling it while on-site; (3) selection and environmental auditing of used oil transporters and recyclers; (4) proper 
disposal of contaminated oil; (5) promotional and public education materials; and (6) recordkeeping and/or other paperwork required by state or federal regulations.

States that require collectors to register can employ the registration process to provide technical assistance. These states may have strict guidelines for the design and siting of the collection tank as well as for oil handling and housekeeping practices. Some funded collection programs set aside funds to support consultants who provide technical assistance to collectors in these areas.

Markets for used oil have traditionally been unstable. Selecting a reputable used oil hauler, negotiating price agreements, and scheduling pickups can be problematic to collectors of DIY oil as well as used oil generators. Chevron received significant positive feedback from participating service stations regarding the used oil transporter assistance (i.e., hauler selection, scheduling, and billing) provided through its pilot voluntary collection program in Sacramento.

Alabama's Project Rose is a good example of a program that supplies information to assist collectors in selecting contractors to transport and recycle their collected oil. Some states (Rhode Island and Maryland) and voluntary programs (Amoco, Quaker State) negotiate with used oil transporters to help arrange free transport for participating collection sites.

\subsubsection{Assessment}

The assessment of a program's effectiveness is considered by most coordinators to bc important. However, many existing programs have not had the funding required to collect and assess quantitative data. California, Florida, Maine, Maryland, and Rhode Island require quarterly and/or annual reporting on their used oil collection programs as part of the funding legislation. Reports from these states were reviewed for this study. While the reports meet the requirements of the state's legislation and were found to be qualitatively informative, they did not contain adequate data to draw general conclusions on program cost effectiveness. Other programs that have assessment requirements are in their infancy and enough time has not clapsed to evaluate them.

Most state programs either consist entirely of or are supplemented by voluntary collection at private establishments. Often these collectors are not required to maintain records of the volumes of oil collected or the number of DIY oil changers who participate, so a comprehensive evaluation of the effectiveness of these programs cannot be conducted.

Cost/benefit assessment of used oil collection programs has many facets. If these assessments are to be employed to compare the effectiveness of different programs, consistent data must be collected. The network of collection options in the local area (along with demographics information) should be mapped, and the volumes of used oil collected and numbers of DIY oil changers returning their oil should be tracked. Researchers should also monitor dollars 
spent in public education, technical assistance, and program coordination. Finally, procedures need to be developed and resources set aside for program assessment.

\subsection{Opportunities for Government to Promote Collection Programs}

In the previous section, we described various components that will enhance the effectiveness of DIY used oil collection programs and provided examples. Local municipalities are best equipped to use these components to design and implement programs for their regions that will be effective given their demographics and resources. The federal government could contribute to their efforts by providing the following tools:

- Funding mandate (e.g., environmental tax/refund program or motor oil sales $\operatorname{tax})$

- Piloted survey or focus group protocol for determining how to motivate local DIY oil changers to recycle their used oil;

- Piloted programs for the recovery of used oil generated by off-road (mining, farming and construction) sources;

- Public education programs and materials;

- Training for used oil program coordinators and collection site managers;

- Environmental audit database and/or service for the selection of used oil haulers and recyclers;

- Protocol for assessing the effectiveness of a used oil collection program; and

- Systems approach for used oil recycling, including reuseable containers and recycling of filters, containers, and other oil-contaminated material. 


\section{Waste Oil Reuse Options}

Households and small farms are not EPA-regulated waste oil generators. Besides returning used oil to a collection site or improperly dumping it, these sources likely practice a myriad of alternative uses (e.g., oiling equipment and livestock, weed killing). Because little information is available to assess the prevalence or environmental impacts of these practices, they are not discussed here, although further investigation of these disposal alternatives is certainly worthwhile. Understanding these alternative uses can, for example, provide critical input to determining what motivates DIY and off-road used oil generators in specific regions of the country to recycle their oil.

All other generators are required by law to (1) burn used oil that they generate or collect from DIY oil changers in space heaters with capacities less than 500,000 Btu/hr; (2) burn, reprocess, or re-refine their oil on-site in accordance with the used oil management standards for recyclers; or (3) contract with a registered EPA transporter to collect their used oil and transport it to a recycler or appropriate disposal facility. After collection, the used oil enters the used oil management system. The reuse options evaluated for this study include the following:

- Source reduction;

- Burning without treatment;

- Reprocessing to fuel;

- Reprocessing in a primary refinery to produce petroleum products;

- Re-refining to lubricating oil in a dedicated unit;

- Re-refining to lubricating oil in a primary lube oil refinery; and

- Disposal.

Although source reduction and disposal are technically not reuse options, they are included to provide a complete discussion of alternatives.

Existing data on the energy, environmental impacts, and economics related to different reuse options do not allow for a thorough, precise evaluation. Because the limited data available in the literature are largely inconsistent or outdated, our conclusions have been derived from engineering judgement and consideration of critical factors only. Different reuse options arc compared on a macroscopic, qualitative level instead of a microscopic, quantitative one. The authors of this study welcome future defense of or debate about these conclusions. 


\subsection{Summary of Options}

\subsubsection{Source Reduction}

The EPA has designated source reduction as the priority strategy for pollution prevention. A modest source reduction goal for lubricating oils of $10 \%$ would yield energy savings of $33 \times 10^{12} \mathrm{Btu} / \mathrm{year}$. This goal may be achievable by directing research efforts toward a high-volume application like automotive engine crankcase oils. Research of engine designs that extend the service life of the oil, reduce its consumption during use, and/or reduce the volume of oil required in the crankcase could be undertaken as part of the Partnership for a New Generation Vehicle.

Advances have been made in these areas. Improved formulations have extended the useful service life of motor oils, and improvements and downsizing of engine designs have reduced the consumption of oil during use, and reduced the volume of oil required in the crankcase. Further advances seem possible.

Energy savings may also be attained by reducing the amount of unrecoverable oil (oil that is burned, leaked, or otherwise consumed during use or somehow separated from the recovered oil). The volume of unrecoverable oil is estimated at $1 \times 10^{9} \mathrm{gal} / \mathrm{yr}$ (Dietly 1992). identified:

In a very limited search for source and loss reduction options, the following ideas werc

- In-line oil condition sensors;

- Engine design changes to reduce oil consumption;

- Engine design changes to reduce the volume of oil required in the crankcase;

- Improvement of oil filtration and/or additive spiking to extend oil life;

- Reduction of waste oil contaminants;

- Elimination of the oil drain plug;

- Hydraulic system replacement; 
- Oil container recycling; and

- Oil filter recycling.

Each of these options is discussed below.

In-Line Oil Condition Sensors. Regular oil changes are required to protect the engine, but the required frequency of these changes is uncertain. Manufacturers recommend oil change intervals for the vehicles they manufacture. Some void the vehicle warranties if these oil changes are not performed. Vehicle owners may follow manufacturers' guidelines, or employ their own system based on time or miles driven to decide when to change their oil. Surveys of DIY oil changers and automobile enthusiasts suggest that these groups change oil more frequently than recommended by the manufacturer.

Accurate and timely feedback on oil quality during service could affect the frequency of oil changes - eliminating unnecessary changes and extending the service life of oils. Oil change indicators that employ algorithms involving oil temperature, vehicle mileage, and/or engine revolutions have been installed in some car models (Schwartz and Smolenski 1987). Other researchers have proposed in-line sensors measuring viscosity, pressure drop, solids contamination, or acidity to monitor oil quality and performance (Hunt 1985; Sorab and VanArsdale 1990; Sen and VanArsdale 1992; Morishita et al. 1993). The cost and weight of these systems currently discourage installation.

Engine Design Changes to Reduce Oil Consumption. Automotive manufacturers may have the greatest incentives to reduce oil consumption in service because of the beneficial side effects, which include lower tailpipe emissions of hydrocarbons and particulates, increased life of exhaust catalysts (zinc phosphates in oil additive packages are known catalyst deactivators), and improved customer perception of vehicle quality. Oil consumption may be reduced by optimizing the design of the three engine systems that consume oil: the power cylinder system, the engine overhead system, and the positive crankcase ventilation (PCV) system (Hill and Sytsma 1991). Some examples of design improvements include using low-leakrate, positive valve stem seals in the engine overhead design; improving cylinder cooling; modifying materials, coatings, and designs of the piston and rings; separating and enlarging flow paths within the PCV system; and installing PCV oil recovery traps.

Engine Design Changes to Reduce the Volume of Oil Required in the Crankcase. The volume of oil in the crankcase is dependent on the design of the engine and the operational requirements for the oil (lubrication, cooling, etc.). The oil volume could potentially be reduced by incorporating self-lubricating seals and parts, although these designs are in their infancy for automotive engines. Freudenberg N.O.K has patented a self-enclosed valve tappet system that has the potential to reduce oil requirements by as much as one third.(Döhring 1994). 
Improved Oil Filtration and/or Additive Spiking to Extend Oil Life. Filtration alone cannot prevent the ultimate degradation of lubricating oils during service. However, innovations in filter design may offer opportunities to increase oil life. For example, a bypass oil filtration system marketed by Full Prime System Inc. is designed to be serviced every 3,000 mi by changing the filter and adding one quart of oil to replace additive loss (in lieu of a full oil changc). This filter is an add-on accessory that works in parallel to a standard full-flow filter (Loveton 1994). The development of filters to capture sub-micron contaminants has also been proposed for oil life extension (Needelman 1994).

Reduction of Waste Oil Contaminants. Another form of source reduction involves minimizing the contaminants in used oil that negatively affect the environment upon reuse. These contaminants enter the oil through the following mechanisms: additive packages in the original lubricating oil formulation, wear and corrosion of lubricated surfaces, degradation and reactions of lubricating oil or additive components, leakage of contaminants into the oil system during use, and mixing of other substances into the waste oil after its use. Some ideas for minimizing these contamination routes include the following: applying a "design for the environment" philosophy to lubricating oil additive package development, replacing materials that contribute toxic wear or corrosion metals to the oils (e.g., lead-containing bearings in automobile engines), modifying designs to minimize external leaks into oil systems, and promoting regulatory and educational programs to reduce occurrences of post-use waste oil contamination.

Elimination of the Oil Drain Plug. The motor vehicle drain plug is a common source of oil leakage during the oil's service life and spillage during oil changes. This low-point drain access could be eliminated by using vacuum oil removal systems designed to allow oil changes through the engine dip stick tube. With well-designed connectors, spill-proof oil changes could be ensured (Gressel 1995; Lee 1995).

Hydraulic System Replacement. New equipment design presents an opportunity to replace traditional hydraulic systems with electric motor designs. Cincinnati Millicron has introduced an injection molding machine with a variable-speed electric motor replacing the hydraulic pressure. system. This design change eliminates oil use and reduces energy consumption. In hydraulic systems, the oil pump must be operated continuously; the oil pressure is controlled by valves, so the system consumes energy even when high oil pressure is not required. The electric motor can be turned on and off as needed (Dish 1994).

Oil Container Recycling. An estimated $25 \times 10^{6} \mathrm{gal} / \mathrm{yr}\left(3 \times 10^{12} \mathrm{Btw} / \mathrm{yr}\right)$ of fresh lube oils are discarded with their original containers. For motor oil, these containers are commonly 1-qt bottles made from high-density polyethylene (HDPE). Residual used oil is also discarded with contaminated plastic containers by DIY oil changers when they drain and recycle thcir oil. Most polymer recyclers will not accept oil-contaminated feedstocks because the oil impedes shredder performance, decreases the effectiveness of wetting agents in the cleaning steps, contributes to "smoking" or volatile emissions from the extruder, and causes wastewater compliance problems. Technology for recycling oil containers does exist and is practiced commercially. Partek Corporation in Vancouver, Washington, collects motor oil containcrs from 
service stations, drains residual oil, shreds and washes the plastic, and produces HDPE pellets for recycle into motor oil bottles (Porter 1994).

Oil Filter Recycling. Representatives of the filter industry estimate that $18 \times 10^{6} \mathrm{gal}$ of oil $\left(2.5 \times 10^{12} \mathrm{Btu}\right)$ and 161,500 tons of steel -could be recovered by recycling all of the 400 million used oil filters generated annually. In 1993, approximately 20 million used oil filters were recycled (Warren 1994). Current barriers to used oil filter recycle include the following: (1) no national filter recycling infrastructure and few collection points, (2) high cost of filter recycle relative to cost of manufacturing new filters, (3) disparate regulations from state to state, and state to federal, (4) non-standard processing technologies that produce different types of feedstocks for steel industry (crushed pucks, shredded or disassembled filters, and densified cubes), and (5) no specifications from steel industry for processed filter feedstocks (Warren 1994).

Additional source and loss reduction ideas need to be solicited from the relevant research and industrial communities. Initially, research efforts should target a single, large-volume lubricating oil application: automobile motor oils. These efforts should be conducted cooperatively between lubricating oil formulators and automobile engine designers.

\subsubsection{Burning without Treatment}

The 1991 Clayton study estimates that $101 \times 10^{6} \mathrm{gal} / \mathrm{yr}$ of used oil is burned in 70,000 space heaters in automotive service bays and municipal garages across the nation (Dietly 1992). The study revealed a 17\% increase in this application between 1988 and 1991. The largest growth is credited to municipal garages that collect DIY used oil. Burning this used oil helps defray the heating costs at public works facilities and reduces the costs of managing DIY used oil.

Used oil heaters can also be equipped with water heater capabilities. Although this equipment increases upfront capital cost, it extends the operating flexibility of the unit. Hot water can be used in summer when space heating is not required.

Two types of used oil heaters have been employed: air atomizing and vaporized pot. The latter heater type has not been marketed by major manufacturers since 1982 . Over $95 \%$ of heaters currently in service are air atomizing units. In this unit, oil is introduced into the burn chamber via a low-pressure atomizing nozzle; there, it is mixed with compressed air and burned. The hot exhaust air is passed through the flue tubes in the heat exchanger cabinet before being vented through the stack. With time, fouling of the tubes from contaminants in the waste oil occurs. Periodic maintenance is required to remove these deposits.

The performance of and emissions from space heaters depend on the maintenance frequency, composition of the waste gas, height of the stack, and furnace settings that define the air-to-fucl ratio, oil droplet size, and flame temperature. 
The environmental impacts of burning waste oil in space heaters were most recently studied by the Vermont Agency of Natural Resources and EPA (Vermont Agency of Natural Resources 1994). Historical environmental data for space heaters, as documented in air emission studies and summary reports, were also reviewed (Walker 1981; Hall et al. 1983; Cooke et al. 1984; Mueller and Associates, Inc., 1989; Elliot 1993; Entropy 1994). Energy and economic data were obtained through discussions with representatives of the Waste Oil Heaters Association (Bosco 1994; Wolf 1994).

Another reuse option classified as "burning without treatment" is the practice of fleet operators adding used oil drained from their diesel engines into their fuel tanks. The 1991 Clayton study estimates that $16 \times 10^{6} \mathrm{gal} / \mathrm{yr}$ of used oil are reused in this way (Dietly 1992). The economic benefit of this reuse option is obvious; the oil collected on-site requires no transportation and replaces diesel fuel (although only a small percent of the total fuel required). Reuse of used oil as a diesel fuel supplement, however, is restricted because of its sulfur content. Sulfur compounds in used oil lead to tailpipe sulfur dioxide emissions when burned in the engine.

A final example of burning without treatment used oil is the burning of oil collected in South Carolina to supplement coal in fueling Santee Cooper utility boilers. In 1993, 360,000 gallons of DIY oil were collected and burned at the Santee Cooper utility. Recent analyses of used motor oil (Elliot 1993) suggest that it may be a cleaner-burning fuel than coal. With collection and transportation costs, however, it may not be a cheaper fuel.

Other burning applications of untreated used oil are not likely to be significant. Used oil that enters the used oil management system is typically processed (at a minimum) to remove water and sediment to meet customer requirements.

\subsubsection{Reprocessing to Fuel}

Equipment and procedures for reprocessing used oil may be as varied as the number of existing reprocessors (over 200). The goals of the reprocessors are to (1) remove water and volatiles to produce a fuel with a consistent heat value, and (2) remove coarse solids to minimize abrasive wear on their customer's equipment. These processes typically do not remove the heavy metals and halogens in the used oil that can lead to fouling, corrosion, and/or emissions at the customer's site.

A three-step reprocessing technology has been assumed for this analysis: (1) removal of water and heavy sediment by settling, (2) removal of particulates by filtration, and (3) control of ash by blending. Some larger-volume reprocessors remove water, light fuels, and chlorinated solvents by distillation; employ centrifuges for more efficient particulate removal; and/or use chemical treatment to break emulsions and/or reduce the content of ash and sulfur. Wastc strcams generated by the reprocessing industry include in-line filter residue, settled wastewater, oily sludges, distillation and tank bottoms, and centrifuge or filter screen solids. 
Reprocessing products are marketed as discounted fuel oils to asphalt plants $(43 \%)$, industrial boilers (14\%), utility boilers $(12 \%)$, steel mills $(12 \%)$, cement/lime kilns $(5 \%)$, marine boilers $(5 \%)$, pulp and paper mills $(4 \%)$, commercial boilers $(<1 \%)$, and others $(5 \%)$ (Entropy 1994). The environmental impacts associated with reprocessing waste oil to fuel depend on the specific fuel application. An emission study sponsored by the Used Oil Recycling Coalition that is currently underway (Entropy 1994) will provide data to assess these different impacts. For this study, burning of reprocessed waste oil is evaluated only on a generic, qualitative level.

Data for the evaluation of reprocessing energy impacts were derived from the following references: Brinkman et al. (1981), Thompson and Brinkman (1981), and Mueller and Associates, Inc., (1989); for environmental impacts from Recon Systems, Inc., (1980), Bider (1985), Mueller and Associates, Inc., (1989), Troy (1989), and Entropy (1994); and for economics from Brinkman et al. (1981), Thompson and Brinkman (1981), and Gressel (1994).

\subsubsection{Reprocessing in a Primary Refinery to Produce Petroleum Products}

Processing of used oil as an alternative to crude oil in refineries has been considered by many oil companies. Several oil company contacts indicated that this option has not been pursued because of concern about used oil contaminants that could potentially deactivate expensive refining catalysts. However, at least two companies (Lyondell and Texaco) have successfully processed used oil in petroleum cokers. Little or no capital equipment is required to feed used oil to the coker. Lyondell's experience has been that used oil fed to the coker yields $90 \%$ hydrocarbons (which are further processed to gasoline, heating oil, jet fuel, kerosene, etc.), $1-3 \%$ coke (which incorporates all its metallic content), and the remainder sour gas (Wulfers 1994).

Essentially $100 \%$ of the waste oil's heavy metal contaminants are entrapped in the petroleum coke product. The ultimate disposition of these contaminants, therefore, depends on the end use of the coke. Petroleum coke is marketed for fuel applications (industrial boilers, utilities, cogeneration plants, and lime and cement kilns) and as a carbon source (silicon carbidc; foundries; coke ovens; or, if calcined as aluminum anodes, titanium dioxide $\left(\mathrm{TiO}_{2}\right)$ pigments, carbon raisers, electrodes, and synthetic graphite).

Several advantages have been identified for processing used oil in refineries: a tradition of employing strict environmental, health, and safety standards at these facilities; flexibility built into the refinery that allows for a nearly $100 \%$ yield of hydrocarbons from the fcedstock; availability of equipment to further process waste streams to useful products (e.g., recovery of sulfur from sour gas); and availability of pollution prevention equipment, such as wastewatcr treatment and air emission scrubbers.

In May 1994, Texaco started up a unit in Marerro, Louisiana, with the capacity to convert $50 \times 10^{6} \mathrm{gal} / \mathrm{yr}$ of used oil to marine diesel fuel. In the patented "Trailblazer" process, used oil is dehydrated in a flash tower, then processed in two stages of vacuum distillation. The 
unit is integrated with an existing refinery, so presumably, the process offers the advantages described above. Details of this process are confidential, however.

Data for the energy, environmental, and economic evaluation of processing waste oil in a primary refinery coker were derived from information supplied by Lyondell (Wulfers 1994) and the following literature on coker processes: Nelson (1976), Gaines and Wolsky (1981), Meyers (1986), Maples (1993), and Gary and Handwerk (1994).

\subsubsection{Re-Refining to Lubricating Oil in a Dedicated Unit}

Several different technologies are offered for license or are in operation for re-refining lubricating oil (Kalnes et al. 1990 and 1989; Che and Kessler 1991; Magnabosco et al. 1991; Schieppati 1991; Strathorn 1991; Chu 1994; Schieppati and Giovanna 1994; and Kenton and Hedberg 1994). Re-refining technologies have evolved in the last two decades from acid-clay to some form of vacuum distillation and post treatment, most commonly hydrotreatment. Table 3 presents a summary of North American re-refineries currently in operation.

A flowsheet of the re-refining process assumed for this evaluation is provided in Figure 4. In this process, water is first removed by atmospheric distillation. Fuel byproducts are separated from the used oil by vacuum distillation, followed by wiped-film vacuum evaporation to isolate the heavy contaminants as an asphalt flux by-product. Hydrotreatment is employed as a post treatment to improve product stability, color, and odor. This catalytic hydrogenation step removes sulfur, oxygen, nitrogen, and chlorine-bearing organic materials as well as polynuclear aromatic (PNA) components. Gas oil and light and heavy neutral base oil products are recovered through fractionation of the hydrotreatment effluent.

Chlorinated solvent contaminants in the waste oil feed are removed through distillation as part of the fuel by-product, which is typically burned on-site to supply process energy. The bulk of the heavy metal waste oil contaminants are concentrated in the wiped-film evaporator residue, which is sold as an asphalt extender. Waste streams from the process include ash from energy recovery and wastewater. The wastewater may be treated chemically or biologically to remove organic contaminants. The sour gas effluent from hydrotreatment is typically burned and treated in alkaline scrubbers to minimize emissions of halogens and sulfur oxides $\left(\mathrm{SO}_{\mathrm{x}}\right)$.

Data for the energy, environmental, and economic evaluation of re-refining technologics were obtained from the following references: McKeagan (1992); Kalnes et al. (1989 and 1990); Brinkman et al. (1981); and Thompson and Brinkman (1981). Data for the comparative evaluation of manufacturing virgin lubricating oil were derived from the following literature sources: Nelson (1976); Gaines and Wolsky (1981); Meyers (1986); Taylor (1986); Zakarian et al. (1987); Maples (1993); and Gary and Handwerk (1994). 
TABLE 3 North American Re-Refiners

\begin{tabular}{|c|c|c|c|c|c|}
\hline Re-Refinery & Location & $\begin{array}{l}\text { Capacity } \\
\left(10^{6}\right. \\
\text { gal/yr })\end{array}$ & $\begin{array}{c}\text { Volume of Used } \\
\text { Oil Processed in } \\
1993 \\
\left(10^{6} \text { gal }\right)\end{array}$ & Process Description & $\begin{array}{c}\text { Source of Waste Re- } \\
\text { Refined Oil }\end{array}$ \\
\hline Breslube (Safety Kleen) & Breslau, Ont. & 34 & 34 & $\begin{array}{l}\text { Vacuum distillation; } \\
\text { wiped-film evaporation; } \\
\text { hydrotreatment }\end{array}$ & $\begin{array}{l}60 \% \text { automotive } \\
>95 \% \text { Canadian sources }\end{array}$ \\
\hline Consolidated Recycling & $\begin{array}{l}\text { Troy, Ind. (southern } \\
\text { Indiana) }\end{array}$ & 12 & 6 & $\begin{array}{l}\text { Vacuum distillation; } \\
\text { wiped-film evaporation; } \\
\text { chemical treatment (PRM } \\
\text { license) }\end{array}$ & $\begin{array}{l}\text { Industrial lubricants } \\
(80 \% \text { closed loop })\end{array}$ \\
\hline DeMenno/Kerdoon & $\begin{array}{l}\text { Compton, Calif. (outside } \\
\text { Los Angeles) }\end{array}$ & 100 & 32 & $\begin{array}{l}\text { Atmospheric and vacuum } \\
\text { distillation; no post } \\
\text { treatment }\end{array}$ & $\begin{array}{l}90 \% \text { automotive } \\
\text { (processed to marine oil if } \\
\text { no market for re-refined } \\
\text { oil) }\end{array}$ \\
\hline Enviropur & $\begin{array}{l}\text { McCook, III. (western } \\
\text { suburb of Chicago) }\end{array}$ & 13.5 & 7 & $\begin{array}{l}\text { Atmospheric and vacuum } \\
\text { distillation; clay treatment }\end{array}$ & $\begin{array}{l}70 \% \text { automotive } \\
30 \% \text { (closed loop) railroad }\end{array}$ \\
\hline Evergreen & $\begin{array}{l}\text { Newark, Calif. (San } \\
\text { Francisco Bay area) }\end{array}$ & 16 & 15 & $\begin{array}{l}\text { Vacuum distillation; } \\
\text { wiped-film evaporation; } \\
\text { hydrotreatment }\end{array}$ & $90 \%$ automotive \\
\hline $\begin{array}{l}\text { Mid-America } \\
\text { Distillations, Inc. }\end{array}$ & Hot Springs, Ark. & 3 & 1.5 & Vacuum distillation & $\begin{array}{l}\text { Industrial synthetics } \\
\text { ( } 75 \% \text { closed loop) }\end{array}$ \\
\hline Mohawk & North Vancouver, B.C. & 9 & 7.5 & $\begin{array}{l}\text { Vacuum distillation; } \\
\text { wiped-film evaporation; } \\
\text { hydrotreatment }\end{array}$ & $\begin{array}{l}\text { Primarily automotive } \\
99 \% \text { Canadian sources }\end{array}$ \\
\hline Safety Kleen & East Chicago, Ind. & 85 & 75 & $\begin{array}{l}\text { Vacuum distillation; } \\
\text { wiped-film evaporation; } \\
\text { hydrotreatment }\end{array}$ & $\begin{array}{l}80 \% \text { automotive } \\
5 \% \text { (closed loop) industrial }\end{array}$ \\
\hline
\end{tabular}




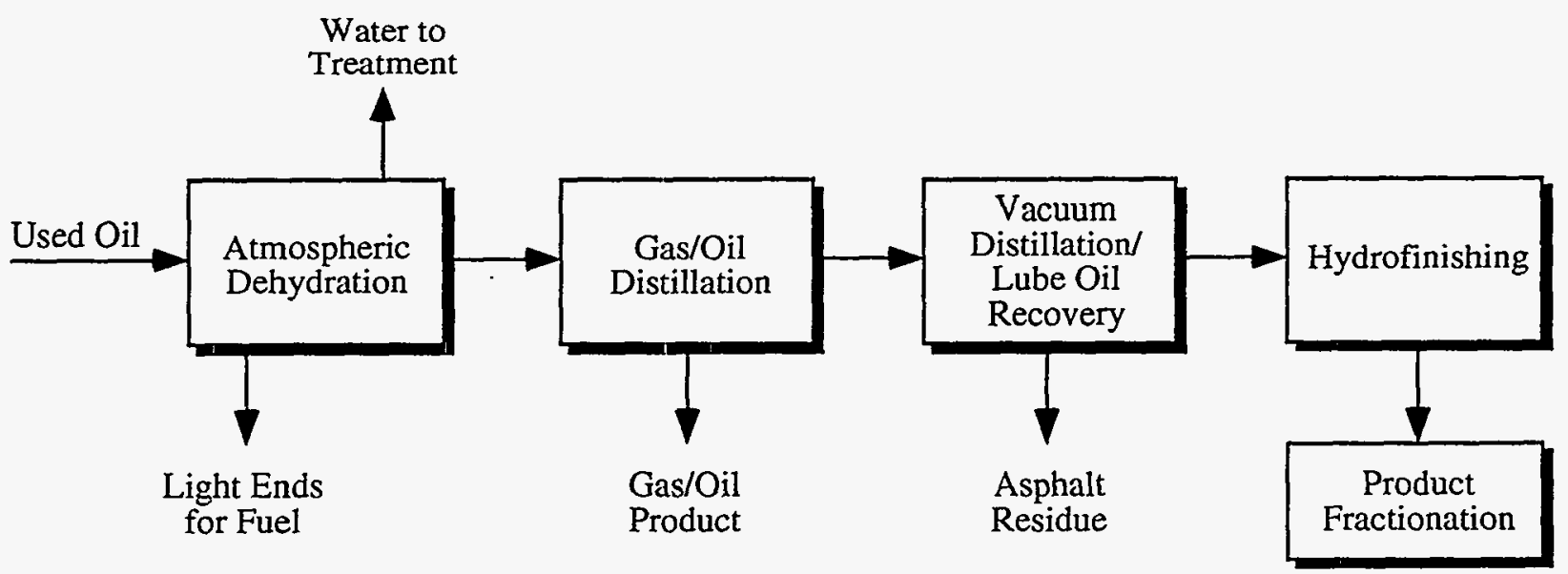

FIGURE 4 Vacuum Distillation/Hydrotreatment Re-Refining Process

\subsubsection{Re-Refining to Lubricating Oil in a Primary Lubricating Oil Refinery}

Although no lubricating oil refineries currently process used oil into lube oil basestock, this option is appealing from a number of perspectives. In the case of automotive crankcase oils, consumer acceptance of re-refined oil is not great. Re-refined product acceptance will grow slowly until a major-name lube oil manufacturer (e.g., Pennzoil, Quaker State, Valvoline, Mobil) incorporates recycled oil into its primary products. The ability of these manufacturers to cost effectively re-refine used oil in their primary lube oil refineries might spur this action.

Potential advantages to re-refining in a lubricating oil refinery mirror those discussed for reprocessing in refinery cokers. Integration of re-refining with existing lubricating oil refineries is proposed to reduce the capital cost involved in re-refining.

UOP, Inc., has offered for license a new re-refining technology: direct contact hydrogenation $(\mathrm{DCH})$. In its literature, UOP describes integration of this process with an existing lubricating oil refinery (Kalnes et al. 1989 and 1990). Figure 5 provides a flowsheet of the DCH process. (Note: UOP and Puralube, Inc., recently announced plans for the construction and 1997 startup of a $16 \times 10^{6} \mathrm{gal} / \mathrm{yr}$ re-refining facility on the East Coast based on UOP's process, tradenamed HyLube. This facility will be a stand-alone unit, however, and will not be integrated with a lubricating oil refinery.)

A company in Utah, Interline, is currently licensing a used oil reprocessing technology that it claims has lower capital and operating costs than the vacuum distillation/hydrofinishing process. The product quality specifications presented in the company's literature would not meet the demanding lubricating oil basestock requirements for automobile crankcase oils. However, product from this process may provide a good-quality feedstock to a hydrotreater. The Interline process flowsheet is presented in Figure 6. 


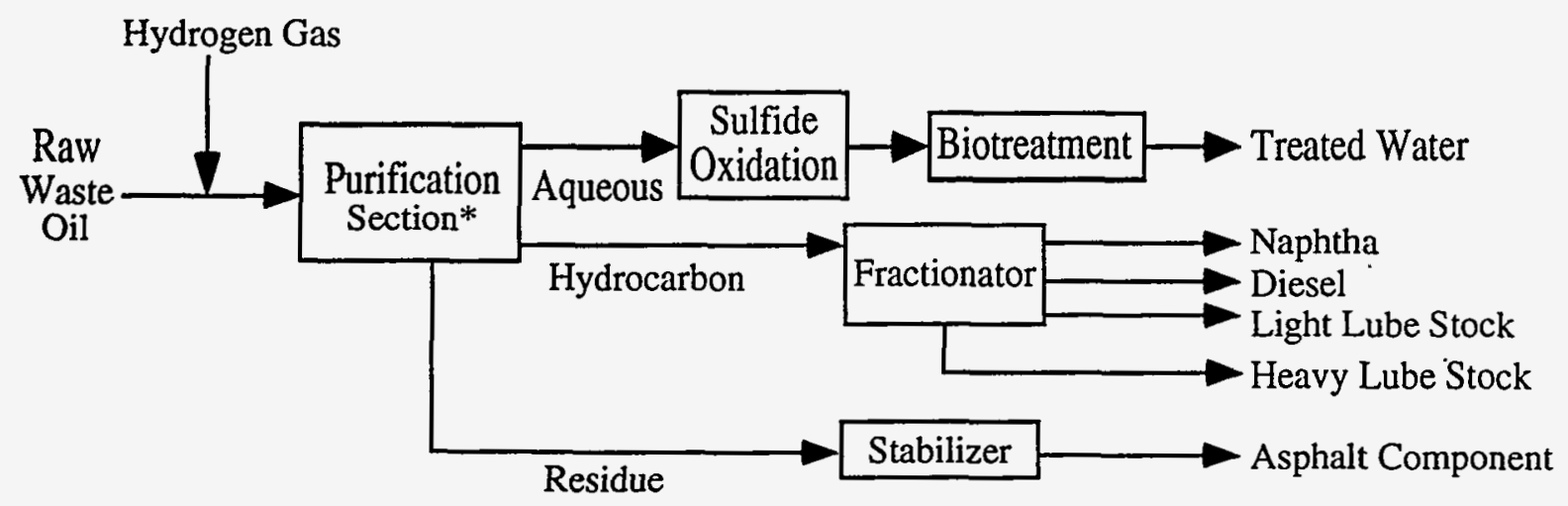

*Purification Section of Process

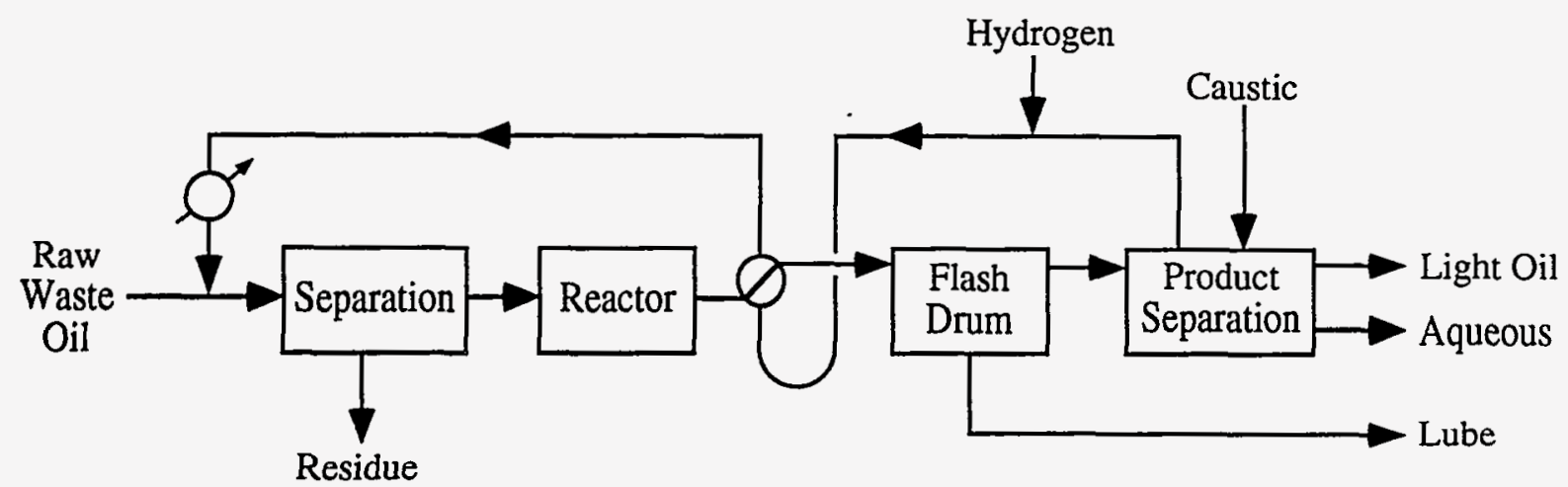

Source: UOP, Inc.

FIGURE 5 Direct Contact Hydrogenation Process (adapted from information supplied by UOP, Inc.)

If used oil could be minimally processed to make it an acceptable feedstock for a lubricating oil refinery hydrotreater, re-refining of oil in existing refineries may be profitable. UOP's DCH process or the Interline process may not represent such technologies, but data on these process alternatives provide input to a preliminary evaluation of this recycling option.

Data for the energy, environmental impact, and economic evaluation of re-refining in a primary lube oil refinery were derived from Morgan (1994) and Kalnes (1989 and 1990).

\subsubsection{Disposal}

In this study, the disposal classification encompasses a myriad of used oil applications that do not involve recycling or reuse. Low-quality oils (high water content or contamination), or oils generated in small quantities in remote areas may be disposed of by industry in landfills or incinerated if the cost of disposal is less than that for collection, transportation, and recycling. Residual oil in reprocessing wastes may also be landfilled or incinerated. 


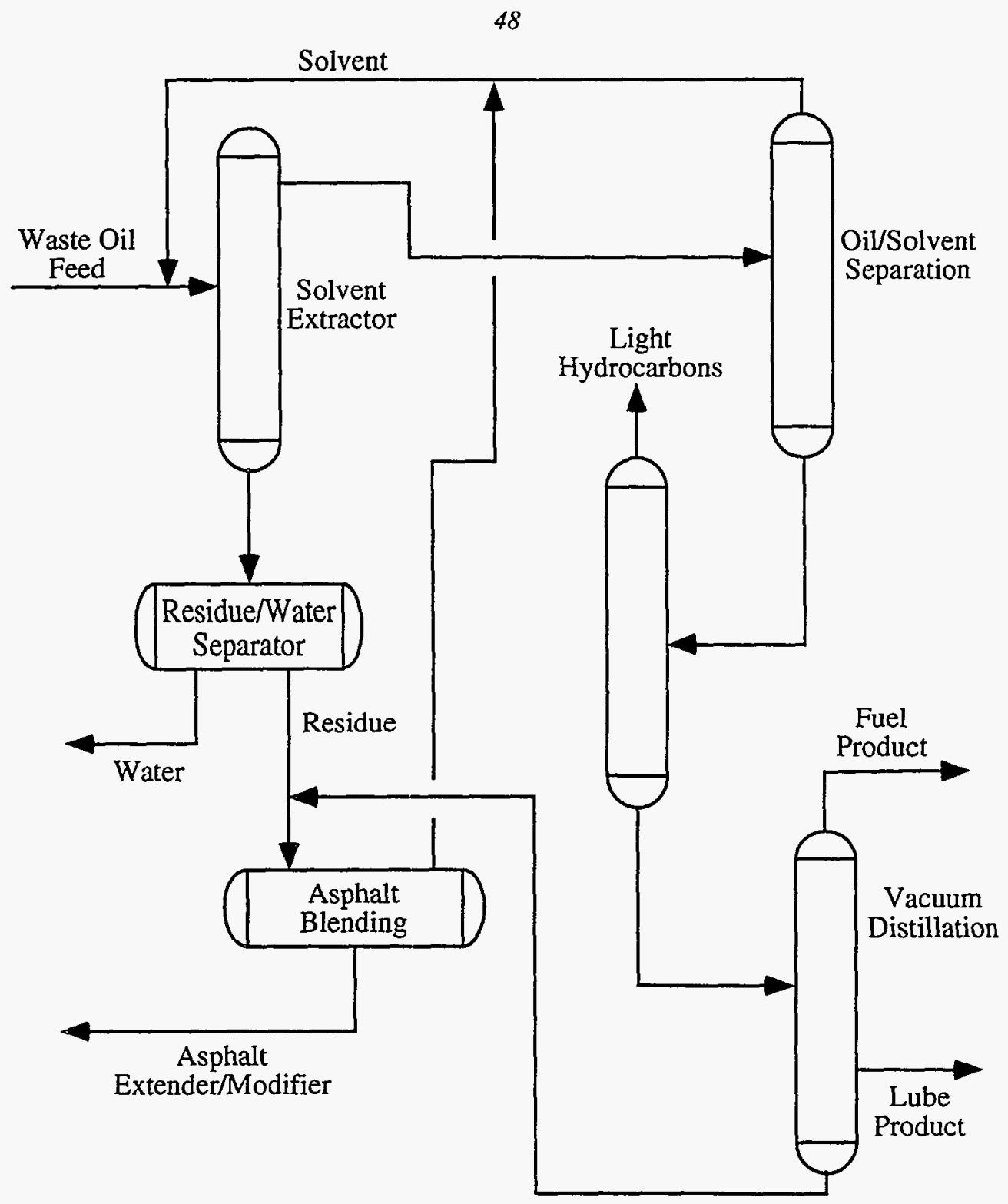

Source: Interline

FIGURE 6 Solvent Extraction/Vacuum Distillation Process (adapted from information supplied by Interline)

Waste oil is disposed of with municipal solid waste, discharged into sewers or drains, or dumped onto the ground surface by DIY oil changers and off-road generators (mining, farming, and construction). These used oil generators may also "misuse" their oil in applications like livestock, road, and equipment oiling and weed killing.

The environmental impacts of waste oil disposal have been investigated in some studies (Surprenant et al. 1983; Bider 1985; Talbot et al. 1990), but these data are not comprehensive enough to establish the environmental consequences of waste oil disposal. Such an assessment would require a massive effort, because the environmental impacts of disposal depend on many factors, including the type of disposal, waste oil contaminants, gcographic and groundwater 
characteristics of the disposal location, local flora and fauna, and design of the landfill or incinerator. For this study, no attempt has been made to draw general conclusions from the existing data. Instead, because none of the energy value of the waste oil can be recovered if the oil is disposed of, this option has been relegated to the bottom of the waste oil reuse hierarchy.

\subsection{Energy Impacts}

Used oil has a heating value of about 138,000 Btu/gal (Mueller and Associates, Inc., 1989), which is nearly equivalent to that of crude oil. This energy is lost if the oil is disposed of. The energy recovered in all other reuse options depends on the energy consumed in collection, transportation, and processing; the energy saved by not manufacturing the substitute virgin products; and the energy value of hydrocarbon products or by-products. Table 4 provides estimates of the energy impacts for the different reuse options.

Used oil typically contains water. For this study, a water content of $4 \%$ was assumed. We also assumed that $100 \%$ of the hydrocarbon value in the used oil is recovered in all reuse options. So the energy recovered for each option is the same, reflecting a $96 \%$ overall yield. This assumption takes into account the fuel value of by-products like asphalt extenders or fuel gas.

Actually, some of the hydrocarbon value will be lost to the wastewater streams and, in the case of reprocessing, to the sludges settled and the solids filtered from the used oil. These losses are small relative to the accuracy of the estimates, however. Qualitatively, yields are expected to be highest when processing in a refinery rather than in a dedicated used oil facility. Refineries are equipped with a variety of processes that can be employed to recover waste hydrocarbons and convert them to marketable products. Yield losses reported for refineries are very low: $0-0.3 \%$.

A processing energy savings is also assumed for the by-products. The justification is that, as long as a by-product can be sold or used, it is replacing a virgin product that would be required in its place. If energy credits are not taken for by-product streams, the assessment of energy impacts would be biased by primary product yields. The energy impacts of re-refining would be most affected because lubricating oil yields (65-80\%) are lower than the fuel yields more typical of reprocessing $(90-95 \%)$.

The results presented in Table 4 reveal that differences in encrgy savings among the various reuse options are small (less than $15 \%$ ) and are likely outside the accuracy of the estimates. Because of the equivalent yield assumption and the small impact of energy consumed for transportation, the differences depend solely on the estimates of process energy requirements. The energy consumption values for individual refinery processes and waste oil reuse options reported in the literature are highly variable. For example, energy consumption data for vacuum distillation/hydrofinishing re-refining ranged from 520,000 to $1,060,000 \mathrm{Btu} / \mathrm{bbl}$ product; virgin lube oil manufacturing data ranged from 545,000 to $3,210,000 \mathrm{Btu} / \mathrm{bbl}$ product; 
Reuse Option

\begin{tabular}{lccccc}
\cline { 2 - 6 } \multicolumn{1}{c}{$\begin{array}{c}\text { Energy Balance } \\
\text { (Btu/bbl waste oil) }\end{array}$} & $\begin{array}{c}\text { Burning without } \\
\text { Treatment in } \\
\text { Space Heaters }\end{array}$ & $\begin{array}{c}\text { Reprocessing to } \\
\text { Fuel and Burning }\end{array}$ & $\begin{array}{c}\text { Reprocessing in } \\
\text { Refinery Coker }\end{array}$ & $\begin{array}{c}\text { Re-Refining in } \\
\text { Dedicated Unit }\end{array}$ & $\begin{array}{c}\text { Re-Refining in } \\
\text { Primary Refinery }\end{array}$ \\
\hline Transportation energy & 0 & $-144,000$ & $-198,000$ & $-198,000$ & $-198,000$ \\
$\begin{array}{l}\text { Processing energy consumed } \\
\text { Processing energy saved b } \\
\text { Energy recovered }\end{array}$ & 0 & $-294,000$ & $-207,000$ & $-742,000$ & $-742,000$ \\
Net energy recovered & 745,000 & 745,000 & 474,000 & $1,722,000$ & $1,722,000$ \\
\hline & $6,564,000$ & $5,564,000$ & $5,564,000$ & $5,564,000$ & $5,564,000$ \\
\hline
\end{tabular}

a Energy consumed and energy saved are estimated for upstream of coker only; downstream process energies consumed and saved cancel one another.

b Processing energy saved = energy required to manufacture substitute desulfurized fuel oil (for burning) or lubricating oil (for re-refining). 
residual energy consumption data for fuel oil production ranged from 330,000 to $780,000 \mathrm{Btu} / \mathrm{bbl}$ product; and delayed coker energy consumption ranged from 100,000 to $210,000 \mathrm{Btu} / \mathrm{bbl}$ product.

Reported data on energy consumptions are variable for several reasons. Each individual refinery and re-refinery is unique; energy consumption depends on the types of process equipment, the processing conditions, the extent of heat and energy integration, and the composition of the crude or waste oil being processed. Also, the method for estimating energy consumption values and distributing these values among different product and by-product streams differs and, in some references, was not clearly specified. For this study, the value for energy consumed per barrel of feed was equal to the energy consumed per barrel of product. This definition is consistent with the assumption of $100 \%$ hydrocarbon yield and the distribution of energy usage equally among all products and by-products.

The energy benefits reflected in these results for burning waste oil in a space heater may be biased high. Although burning waste oil at the site of collection will save costs for transportation and additional processing energy, the following issues could minimize the benefits: (1) space heaters may (in some cases) be operated only to consume used oil when they would otherwise be left idle, and (2) the energy recovered may be reduced by contaminants (e.g., flame instability and uneven burning caused by water content, heat transfer fouling from metals and particulates) that otherwise could have been removed by reprocessing.

Results of this energy analysis suggest that greater energy savings will result if waste oil is re-refined rather than burned as fuel. Consideration of more than one cycle of use for re-refined oil strengthens this conclusion. The energy impact assessment for multiple use cycles is summarized in Table 5. Because the average service life of lubricating oils is less than one year, consideration of multiple use cycles is justifiable. Clearly, if multiple use cycles are considered, re-refining offers a significant energy savings advantage over other reuse options. On the basis of the assumptions described above, if all waste oil that is currently reprocessed or disposed of is recovered and re-refined, a total of $250 \times 10^{12} \mathrm{Btu} / \mathrm{yr}$ could be saved. The position of re-refining near the top of the reuse hierarchy is a result of these potential energy savings.

\subsection{Environmental Impacts}

Used oil disposed of in landfills or discharged to the ground or into sewers can contaminate groundwater or surface waters. Like many petroleum products, used oil contains organic toxins (e.g., benzene, toluene, naphthalene, phenols, and PNAs such as benzo[ $\alpha]$ pyrene) at levels higher than health-based standards. Although the environmental impacts of used oil disposal have not been definitively determined, recovering this oil can be defended on the basis of energy savings alone, so extensive studies on environmental impacts are not required to justify promoting waste oil recovery and recycle. 
TABLE 5 Assessment of Re-Refining Energy, with Multiple Use Cycles Assumed

\begin{tabular}{|c|c|c|c|c|c|c|}
\hline \multirow[b]{2}{*}{ Assessment Category } & \multicolumn{6}{|c|}{ Energy Balance (Btu/bbl original waste oil) } \\
\hline & 1st Cycle & 2nd Cycle & 3rd Cycle & 4th Cycle & 5th Cycle & Total \\
\hline Transportation energy & $-198,000$ & $-118,000$ & $-70,000$ & $-41,000$ & $-25,000$ & $-452,000$ \\
\hline Processing energy consumed & $-742,000$ & $-441,000$ & $-262,000$ & $-155,000$ & $-92,000$ & $-1,692,000$ \\
\hline Processing energy saved & $1,722,000$ & $1,023,000$ & 608,000 & 361,000 & 214,000 & $3,928,000$ \\
\hline Energy recovered & $5,564,000$ & $3,305,000$ & $1,963,000$ & $1,166,000$ & 693,000 & $12,691,000$ \\
\hline Net energy recovered & $6,346,000$ & $3,769,000$ & $2,239,000$ & $1,331,000$ & 790,000 & $14,475,000$ \\
\hline
\end{tabular}

Assumptions: $66 \%$ yield for lubricating oil, $20 \%$ additives in formulated product oil, and $75 \%$ recovery of used oil. 
The environmental impacts of reuse technologies depend on the composition of the feed waste oil. Contaminants can be imparted to the waste oil by the following mechanisms: (1) during formulation, from the additive package; (2) during use, from leaks into the lube system (e.g., blow-by in automobile engines), degradation of oil or additives, and/or corrosion and wear of materials; and (3) after use, during handling or storage, from intentional or unintentional addition of other materials (e.g., chlorinated solvents). With the exception of aviation and metalworking fluids, automotive-sector used oils typically have the highest concentration of contaminants; this is caused, in large part, by the higher concentration of additives in the virgin lubricating oil product.

Significant environmental benefits would result from the adoption by lubricating oil manufacturers of a "design for environment" philosophy in formulating their products. To some extent, the industry has begun to implement this philosophy, as evidenced by the fact that manufacturers have discontinued use of barium-containing additives in their motor oils.

Many of the data concerning the environmental impacts of reuse technologies were collected during trials in which automotive crankcase oils were used as the feedstock. These studies were conducted prior to 1985, when the composition of used automotive oils differed significantly from that of the used oil generated today; specifically, lead content (greater than $1,000 \mathrm{ppm}$ ) and barium content (greater than $200 \mathrm{ppm}$ ) were higher than they are today. Used oil samples were analyzed in three more recent independent studies (Elliot 1994; Entropy 1994; and 40 CFR Parts 261 and 266), and the compositions reported in these references are relatively consistent. In Table 6, the composition of used automotive oils is compared to that of crude oil and other fuels.

The data in Table 6 suggest that used oil, either untreated or reprocessed, would be a cleaner-burning fuel than coal. In South Carolina, one public utility (Santee Cooper) has an ongoing program to collect used oil from DIY oil changers and burn the oil untreated in its coalfired utility boilers. Comparing the compositions of used oil and coal, some reduction in environmental impact might be expected from this substitution. However, because the used oil constitutes only a very small fraction (less than 1\%) of the utility's fuel needs, its impact is minimal. For this application, the costs of collecting, transporting, and handling the used oil must be weighed against the low cost of coal.

Results from a recently completed study on the environmental impacts of burning waste oil in space heaters (Vermont Agency of Natural Resources 1994) revealed higher levels of arsenic, barium, cadmium, chromium, lead, zinc, ash, chlorine, and bromine in used motor oils versus No. 2 home heating fuel oil. Emissions of hydrochloric acid, total particulates, lead, and chromium from space heaters were higher (although still in compliance with Vermont standards) when burning waste oil than when burning No. 2 fuel oil. Compliance with emission standards for hexavalent chromium, arsenic, and cadmium while burning waste oil could not be confirmed because of limitations in the analytical detection methods. While the study recognized the air quality benefits that would result from prohibiting burning of waste oil in space heaters, the authors concluded that these benefits would not compensate for the adverse economic impact associated with such a prohibition. 
TABLE 6 Compositions of Used Oils and Other Fuels

\begin{tabular}{|c|c|c|c|c|c|c|c|}
\hline Component & $\begin{array}{c}\text { Used Gasoline } \\
\text { Engine Oila }\end{array}$ & $\begin{array}{l}\text { Used Diesel } \\
\text { Engine Oila }\end{array}$ & Virgin Lube ${ }^{a}$ & \#4 Fuel Oila & $\begin{array}{l}\text { Residual } \\
\text { Fuel Oilb }\end{array}$ & Crude Oilc & $\begin{array}{c}\text { North American } \\
\text { Coals }^{\text {d }}\end{array}$ \\
\hline Ash, wt\% & 0.54 & 0.46 & 0.14 & 0.55 & $0-.5$ & $0.01-.12$ & $5-14$ \\
\hline Sulfur, wt $\%$ & 0.36 & 0.25 & 0.36 & 0.19 & $.3-.4$ & $0.1-3.8$ & $1.5-6$ \\
\hline Nitrogen, wt\% & 0.04 & 0.02 & 0.02 & 0.03 & $N A^{\theta}$ & $0.05-0.3$ & $1-2$ \\
\hline Barium, ppm & 2.7 & 3.4 & $<1.0$ & $<1.0$ & $0.7-95$ & NA & NA \\
\hline Beryllium, ppm & $<0.02$ & $<0.02$ & $<0.02$ & $<0.02$ & NA & NA & NA \\
\hline Cadmium, ppm & 1.5 & 2.4 & $<0.25$ & $<0.25$ & 0 & NA & NA \\
\hline Chromium, ppm & 3.2 & 3.9 & $<2$ & $<2$ & $13-14$ & NA & $9-330$ \\
\hline Lead, ppm & 47.2 & 57 & $<20$ & $<20$ & $1.7-4.1$ & NA & $7-40$ \\
\hline Nickel, ppm & 1 & 1.8 & $<1.2$ & 8.4 & $3-118$ & 1.55 & $3-200$ \\
\hline Zinc, ppm & 1,162 & 1,114 & 1,210 & 9 & 0 & NA & $20-240$ \\
\hline Halogens, ppm & 350 & 234 & $<200$ & $<200$ & NA & NA & $40-3,000$ \\
\hline
\end{tabular}

a Source of data: Elliot 1993.

b Source of data: Mueller and Associates, Inc., 1989.

c Source of data: HPI Consultants 1987.

d Source of data: Prather et al. 1979.

- NA = Not available. 
Relative to fuel oils, used automotive oils have a higher content of ash and heavy metals. The sulfur content of waste oils falls between those of low- and high-sulfur fuel oils. Sulfur in the waste oil originates from the sulfonate and sulphate additives. The ash components result from metals, dust, and dirt deposited during use, and from the phosphorous, zinc, calcium, and other inorganics in the virgin lubricating oil additive packages. A higher ash content leads to higher particulate emissions in burning applications. Since the phase down of lead in gasoline and the reduction of barium in lube oil additives, the toxicity of these particulates may not be great, however. Reprocessors commonly reduce the ash content in their used oil (mostly by blending with virgin fuel oils) to increase its marketability. In re-refining, the ash components likely contribute to deactivation of hydrogenation catalysts.

The high concentration of inorganic species in used oils presents a problem when these oils are used as a replacement for crude oil feedstock to a refinery. These components can deactivate catalysts and foul equipment surfaces. High concentrations of halogens can lead to costly corrosion. Although because of the volume of used oil that is generated, this source could supply only a fraction (less than $1 \%$ ) of the crude oil consumed daily in domestic refineries, most oil companies are reluctant to consider this feedstock source. Two companies, Lyondell and Texaco, that are feeding used oil in their refineries feed it to a coker, where nearly $100 \%$ of the inorganic species are trapped in a petroleum coke matrix.

Given the scarcity of recent data and the high variability in historical data, a qualitative approach to evaluating environmental impacts has been taken in this study. Information provided in Table 7 highlights the disposition of key waste oil contaminants and the generation of waste streams for different technology options, as derived from data published in the literature. No serious environmental consequences were identified for any of the technology options. Some distinctions in the environmental impacts of the different technologies were apparent, however:

- Trapping heavy metals in an asphalt matrix may be preferable to emitting them into air or landfilling them as ash or oily sludges - an advantage of re-refining versus other reuse options.

- Refineries are generally equipped with more effective waste treatment facilities (for removal and recovery of phenols and other organics from the water discharged) and a greater capacity to recover sulfur rather than emitting it as $\mathrm{SO}_{\mathrm{x}}$ to the air - an advantage to processing in primary refineries versus in dedicated units.

- Removal of heavy metals prior to burning or effective air pollution control equipment could potentially reduce heavy metal emissions - an advantage to reprocessing and burning with air pollution control equipment versus burning without treatment. 
TABLE 7 Environmental Impacts of Waste Oil Reuse Options

\begin{tabular}{|c|c|c|c|c|c|}
\hline Contaminant & $\begin{array}{l}\text { Burning in } \\
\text { Space Heaters }\end{array}$ & $\begin{array}{l}\text { Reprocessing } \\
\text { to Fuel and Burning }\end{array}$ & $\begin{array}{l}\text { Reprocessing in } \\
\text { Refinery Coker }\end{array}$ & $\begin{array}{l}\text { Re-Refining in } \\
\text { Dedicated Unit }\end{array}$ & $\begin{array}{l}\text { Re-Refining in } \\
\text { Primary Refinery }\end{array}$ \\
\hline Lead & $\begin{array}{l}>50 \% \text { to air, } \\
\text { balance to deposits }\end{array}$ & $\begin{array}{l}>50 \% \text { to air } \\
\text { (>90\% less with control } \\
\text { equipment) balance to deposits, } \\
\text { ash }\end{array}$ & $\begin{array}{l}-100 \% \text { to coke } \\
\text { disposition dependent } \\
\text { on coke use }\end{array}$ & $\sim 100 \%$ to asphalt & $-100 \%$ to asphalt \\
\hline Cadmium & $\begin{array}{l}>50 \% \text { to air, balance } \\
\text { to deposits }\end{array}$ & $\begin{array}{l}>50 \% \text { to air, } \\
\text { (>90\% less with control } \\
\text { equipment) balance to deposits, } \\
\text { ash }\end{array}$ & $\begin{array}{l}-100 \% \text { to coke } \\
\text { disposition dependent } \\
\text { on coke use }\end{array}$ & - 100\% to asphalt & $-100 \%$ to asphalt \\
\hline Chromium & $\begin{array}{l}<50 \% \text { to air, balance } \\
\text { to deposits }\end{array}$ & $\begin{array}{l}>50 \% \text { to air } \\
\text { (>90\% less with control } \\
\text { equipment) balance to deposits, } \\
\text { ash }\end{array}$ & $\begin{array}{l}-100 \% \text { to coke } \\
\text { disposition dependent } \\
\text { on coke use }\end{array}$ & $\sim 100 \%$ to asphalt & $-100 \%$ to asphait \\
\hline Zine & $\begin{array}{l}\sim 50 \% \text { to air, balance } \\
\text { to deposits }\end{array}$ & $\begin{array}{l}>50 \% \text { to air ( }>30 \% \text { less with } \\
\text { control equipment) balance to } \\
\text { deposits, ash }\end{array}$ & $\begin{array}{l}-100 \% \text { to coke } \\
\text { disposition dependent } \\
\text { on coke use }\end{array}$ & $\sim 100 \%$ to asphalt & $\sim 100 \%$ to asphalt \\
\hline Sulfur & $\mathrm{SO}_{\mathrm{x}}$ to air & $\begin{array}{l}\mathrm{SO}_{\mathrm{x}} \text { to air, possibly scrubbed to } \\
\text { form neutral salt }\end{array}$ & $\begin{array}{l}\text { Sulfur recovered from } \\
\text { sour gas }\end{array}$ & $\begin{array}{l}\text { Burned to } \mathrm{SO}_{\mathrm{x}} \text { - } \\
\text { scrubbed with caustic to } \\
\text { form neutral salt }\end{array}$ & $\begin{array}{l}\text { Sulfur recovered from } \\
\text { sour gas }\end{array}$ \\
\hline Nitrogen & $\mathrm{NO}_{x}$ to air & $\mathrm{NO}_{\mathrm{x}}$ to air & $\begin{array}{l}\mathrm{NO}_{x} \text { to air or pollution } \\
\text { control equipment }\end{array}$ & $\begin{array}{l}\mathrm{NO}_{x} \text { to air or pollution } \\
\text { control equipment }\end{array}$ & $\begin{array}{l}\mathrm{NO}_{x} \text { to air or pollution } \\
\text { control equipment }\end{array}$ \\
\hline $\begin{array}{l}\text { Polynuclear } \\
\text { hydrocarbon }\end{array}$ & $\mathrm{CO}_{x}$ to air & $\mathrm{CO}_{\mathrm{x}}$ to air & To petroleum product & $\begin{array}{l}\text { Removed by } \\
\text { hydrotreatment }\end{array}$ & $\begin{array}{l}\text { Removed by } \\
\text { hydrotreatment }\end{array}$ \\
\hline $\begin{array}{l}\text { Chlorinated } \\
\text { hydrocarbons }\end{array}$ & $\begin{array}{l}\mathrm{HCl} \text { to air (minimized } \\
\text { in feeds) }\end{array}$ & $\begin{array}{l}\mathrm{HCl} \text { to air, possibly scrubbed to } \\
\text { form neutral salt }\end{array}$ & $\begin{array}{l}\mathrm{HCl} \text { to sour gas } \\
\text { processing }\end{array}$ & $\begin{array}{l}\mathrm{HCl} \text { scrubbed with } \\
\text { caustic to form neutral } \\
\text { salt }\end{array}$ & $\begin{array}{l}\mathrm{HCl} \text { to sour gas } \\
\text { processing }\end{array}$ \\
\hline
\end{tabular}


TABLE 7 (Cont.)

\begin{tabular}{|c|c|c|c|c|c|}
\hline Contaminant & $\begin{array}{l}\text { Burning in } \\
\text { Space Heaters }\end{array}$ & $\begin{array}{l}\text { Reprocessing } \\
\text { to Fuel and Burning }\end{array}$ & $\begin{array}{l}\text { Reprocessing in } \\
\text { Refinery Coker }\end{array}$ & $\begin{array}{l}\text { Re-Refining in } \\
\text { Dedicated Unit }\end{array}$ & $\begin{array}{l}\text { Re-Refining in } \\
\text { Primary Refinery }\end{array}$ \\
\hline Phenols & $\mathrm{CO}_{\mathrm{x}}$ to air & $\mathrm{CO}_{x}$ to air, fraction to wastewater & $\begin{array}{l}\text { To petroleum product } \\
\text { or to wastewater } \\
\text { treatment }\end{array}$ & $\begin{array}{l}\text { To fuel by-product or to } \\
\text { wastewater treatment }\end{array}$ & $\begin{array}{l}\text { To petroleum product } \\
\text { or to wastewater } \\
\text { treatment }\end{array}$ \\
\hline Waste streams & Ash deposits & $\begin{array}{l}\text { In-line filter solids, olly sludges, } \\
\text { wastewater, tank bottoms; ash } \\
\text { after burning }\end{array}$ & $\begin{array}{l}\text { Wastewater, tank } \\
\text { bottoms, ash from } \\
\text { energy recovery }\end{array}$ & $\begin{array}{l}\text { Wastewater, tank } \\
\text { bottoms, ash from } \\
\text { energy recovery }\end{array}$ & $\begin{array}{l}\text { Wastewater, tank } \\
\text { bottoms, ash from } \\
\text { energy recovery }\end{array}$ \\
\hline
\end{tabular}

Notes: $\mathrm{SO}_{\mathrm{x}}=$ sulfur oxides, $\mathrm{NO}_{\mathrm{x}}=$ nitrogen oxides, and $\mathrm{HCl}=$ hydrogen chloride. 
The impacts of air emissions from burning used oil depend on many factors other than those included in this study's simplified analysis; examples include location, type of processing equipment, type of pollution control equipment, stack height, and type of substitute fuel. A study currently underway by the Used Oil Recycling Coalition should provide important information regarding the impacts of burning used oil in industrial boilers.

\subsection{Economics}

The economic assessment of reuse alternatives is complicated by the fact that critical economic parameters (capacity and product price) are not the same for all options. For example, reprocessors are regional businesses and, with average capacities of $1-5 \times 10^{6} \mathrm{gal} / \mathrm{yr}$ of used oil, produce a discounted fuel oil. Re-refiners have larger capacities (e.g., Safety-Kleen's capacity is $85 \times 10^{6} \mathrm{gal} / \mathrm{yr}$ ) and produce a higher-value product: lubricating oil basestock. The magnitude of the cash flows for these two options is therefore very different. Burning used oil in space heaters does not produce a product, so consideration of the substitute fuel savings is more pertinent. For processing in a refinery, the used oil is distributed among several different petroleum products with different values. The economics of these cases are simplified by considering the savings realized by replacing the crude oil that would otherwise be consumed.

Although direct comparisons are difficult, important information can be obtained from an economic analyses of the different reuse technologies. These economic estimates are presented in Table 8. A cash flow analysis was conducted assuming a $20 \%$ desired rate of return. Simple paybacks are also reported because reprocessors and space heater owners would likely require less than a $20 \%$ rate of return for their investments.

To assess the cost-effectiveness of reuse options, their economics are compared to those of virgin product manufacture. The economics of re-refining are compared to those of lubricating oil manufacture, and the economics of reprocessing are compared to those of fuel oil manufacture. Data on the costs of virgin product manufacture are difficult to extract from refinery economic information because of the variety of processing and stream blending that occurs. This study assumes that the sales prices of fuel oil and lubricating oil basestock are representative of the actual costs of virgin product manufacture.

By burning used oil in space heaters, the owners can avoid the costs of used oil transport and substitute fuel for heating. These benefits are limited by the amount of used oil the facilitics generate and their need for heating (this need can be increased by adding water heating capabilities). The economics of space heaters appear to be attractive enough for this reuse option to continue to consume significant quantities of used oil.

For reprocessing and re-refining, capital investment can be a major factor in detcrmining profitability. The capital investment requirements for reprocessing in dedicated equipment or in a refinery are typically low. For a reprocessor, capital costs will depend primarily on the 
TABLE 8 Economics of Waste Oil Reuse Options

\begin{tabular}{|c|c|c|c|c|c|c|}
\hline Economic Factors & $\begin{array}{l}\text { Burning without } \\
\text { Treatment in } \\
\text { Space Heaters }\end{array}$ & $\begin{array}{c}\text { Reprocessing } \\
\text { to Fuel and } \\
\text { Burning }\end{array}$ & $\begin{array}{c}\text { Reprocessing } \\
\text { in Refinery } \\
\text { Coker }\end{array}$ & $\begin{array}{l}\text { Re-Refining in } \\
\text { Dedicated Unit }\end{array}$ & $\begin{array}{l}\text { Re-Refining } \\
\text { by DCH }\end{array}$ & $\begin{array}{l}\text { Re-Refining in } \\
\text { Primary } \\
\text { Refinery }\end{array}$ \\
\hline Capital cost (\$) & 4,500 & 240,000 & 500,000 & $21,500,000$ & $11,400,000$ & $10,600,000$ \\
\hline Capacity (gal used oil/yr) & 2,500 & $5,000,000$ & $20,000,000$ & $20,000,000$ & $20,000,000$ & $20,000,000$ \\
\hline Product price ( $(\phi / g a l)$ & $40^{a}$ & 36 & $40^{a}$ & 95 & 95 & $40^{\mathrm{a}}$ \\
\hline Used oil price ( $\phi / g a l)$ & $-12^{b}$ & 15 & 15 & 15 & 15 & 15 \\
\hline \multicolumn{7}{|l|}{ Annual Cash Flow } \\
\hline Used oil & -300 & 750,000 & $3,000,000$ & $3,000,000$ & $3,000,000$ & $3,000,000$ \\
\hline Hydrogen & & & & 570,200 & $1,149,000$ & \\
\hline Catalyst and chemicals & & & & 400,000 & 400,000 & 22,900 \\
\hline Electricity & 20 & 9,200 & & 348,500 & 550,000 & 118,800 \\
\hline Steam & & & & 198,000 & 96,000 & \\
\hline Fuel & & & & 653,400 . & 666,000 & 353,300 \\
\hline Waste treatment & & 143,900 & & 400,000 & 400,000 & 454,500 \\
\hline $\begin{array}{l}\text { Fixed costs (labor, maintenance, } \\
\text { insurance) }\end{array}$ & 200 & 111,600 & & $1,131,500$ & 815,000 & 522,800 \\
\hline Total expenses & -80 & $1,014,700$ & $3,000,000$ & $6,701,600$ & $7,076,000$ & $4,472,300$ \\
\hline \multicolumn{7}{|l|}{ Revenues $(\$ / y r\rangle$} \\
\hline $\begin{array}{l}\text { Product or substitute savings } \\
\text { By-products }\end{array}$ & 1,000 & $1,728,000$ & $7,680,000$ & $\begin{array}{r}12,540,000 \\
1,600,000 \\
\end{array}$ & $\begin{array}{r}12,600,000 \\
1,951,000 \\
\end{array}$ & $\begin{array}{l}6,000,000 \\
1.122,000\end{array}$ \\
\hline Total revenues & 1,000 & $\overline{1,728,000}$ & $7,680,000$ & $14,140,000$ & $14,551,000$ & $7,122,000$ \\
\hline Capital charge $(20 \%$ rate of return) & 1,500 & 125,400 & 161,000 & $7,377,200$ & $4,066,500$ & $3 ; 682,000$ \\
\hline Net cash flow & -420 & 587,900 & $4,519,000$ & 61,200 & $3,408,500$ & $-1,032,300$ \\
\hline Simple payback (yr) & 4.2 & 0.3 & 0.1 & 2.9 & 1.5 & 4.0 \\
\hline
\end{tabular}


TABLE 8 (Cont.)

\begin{tabular}{|c|c|c|c|c|c|c|}
\hline Economic Factors & $\begin{array}{l}\text { Burning without } \\
\text { Treatment in } \\
\text { Space Heaters }\end{array}$ & $\begin{array}{l}\text { Reprocessing } \\
\text { to Fuel and } \\
\text { Burning }\end{array}$ & $\begin{array}{c}\text { Reprocessing } \\
\text { in Refinery } \\
\text { Coker }\end{array}$ & $\begin{array}{l}\text { Re-Refining in } \\
\text { Dedicated Unit }\end{array}$ & $\begin{array}{l}\text { Re-Refining } \\
\text { by DCH }\end{array}$ & $\begin{array}{c}\text { Re-Refining in } \\
\text { Primary } \\
\text { Refinery }\end{array}$ \\
\hline \multicolumn{7}{|c|}{$\begin{array}{l}\text { Production Cost Breakdown } \\
\text { ( } ₫ / \text { gal product })\end{array}$} \\
\hline Net raw materials & Not Applicable & 16 & 15 & 15 & 17 & 13 \\
\hline Catalyst and chemicals & Not Applicable & & & 3 & 3 & 0 \\
\hline Utilities & Not Applicable & 3 & & 12 & 13 & 6 \\
\hline Fixed costs & Not Applicable & 2 & & 9 & 6 & 4 \\
\hline Capital charge (20\% return) & Not Applicable & 3 & 1 & 56 & 31 & 25 \\
\hline TOTAL & Not Applicable & 24 & 16 & 95 & 70 & 47 \\
\hline
\end{tabular}

a Price of substitute crude or fuel oil.

b Cost diverted for used oil collection. 
complexity of the processes employed and the volume of used oil processed. The capital costs of settling, filtration, and blending are low. A reprocessor employing these process steps with a used oil capacity as low as $1 \times 10^{6} \mathrm{gal} / \mathrm{yr}$ will incur capital costs of less than $4 \phi / \mathrm{gal}$ product. Profit margins decrease, however, if additional processing (e.g., chemical treatment) is employed to reduce used oil contaminant levels. Only reprocessors with larger capacities are likely to be in a position to consider alternative reprocessing technologies to generate cleaner-burning fuels.

The primary costs for the reprocessor are for used oil feed and its transportation. The price of used oil is set by the price that regional reprocessors are willing to pay (or need to charge), given the discounted sales prices they can get for their fuel product. The profit margin squeeze created by regional competition limits the capability of reprocessors to adopt new technologies for processing used oil into fuel. So research devoted to development of reprocessing technologies is not recommended.

In today's market, reprocessors typically transport used oil from collection sites free of charge. They incur a cost of about 10-15 //gal transporting the collected oil to their sites. Re-refiners and nationally based transporters may charge $5-15 \phi / g a l$ to collect used oil to allow them to cover their costs for transporting longer distances. Used oil generators may choose to pay for this service based on the reputations of these firms; essentially attempting to minimize the potential for future liabilities associated with the used oil.

In some regions, the purchase and transport costs of used oil may be greater than the 15\%/gal reflected in Table 8. For example, costs to transport and store used oil at a refinery could substantially increase the raw material costs for this option. In evaluating reprocessing at a primary refinery, used oil is considered a substitute feedstock to heavy crude oil - a feedstock that has only a negligible impact on refinery operating costs. Given these assumptions, reprocessing used oil in a refinery appears to be profitable as long as the total cost for used oil collection, transportation, and storage is at least $5 \not /$ gal less than the price of crude oil.

The capital costs associated with re-refining have long been identified as an obstacle to the expansion of this reuse option. Our study resulted in the same conclusion. To explore the capital cost of this alternative, we investigated the effects of capacity, feedstock cost, and capital cost for the re-refining option. The results are shown in Table 9.

The economics alone suggest a need to develop less capital-intensive re-refining technologies. However, the possibility of discovering a radically new and simple technology seems remote. Also, the current obstacles to increased re-refining go beyond technology issues. Customer acceptance of re-refined motor oils is also a significant hurdle. The needed consumer confidence may be obtained only when well-known, quality lubricating oil manufacturers (e.g., Pennzoil, Quaker State, Valvoline, Mobil) and car manufacturers (e.g., Ford, General Motors, Chrysler) embrace re-refined products and support their use. 
TABLE 9 Economics of Re-Refining

\begin{tabular}{lcccc}
\hline \multicolumn{1}{c}{ Case } & $\begin{array}{c}\text { Waste Oil Cost } \\
\text { ( } \$ / \text { gal) }\end{array}$ & $\begin{array}{c}\text { Capacity } \\
\text { (gal/yr waste oil) }\end{array}$ & $\begin{array}{c}\text { Capital Cost } \\
\left(\$ 10^{6}\right)\end{array}$ & $\begin{array}{c}\text { Production Cost } \\
(\phi / \text { gal product) }\end{array}$ \\
\hline Base & 15 & $20,000,000$ & 21.5 & 95 \\
Low feedstock cost & 0 & $20,000,000$ & 21.5 & 72 \\
High feedstock cost & 30 & $20,000,000$ & 21.5 & 118 \\
Low capital cost & 15 & $20,000,000$ & 10.0 & 63 \\
High capital cost & 15 & $20,000,000$ & 30.0 & 118 \\
Low capacity & 15 & $10,000,000$ & 21.5 & 116 \\
High capacity & 15 & $50,000,000$ & 21.5 & 75 \\
\hline
\end{tabular}

Re-refining technologies that appear to be less capital intensive than vacuum distillation/hydrofinishing have been piloted by UOP and Interline. Table 8 presents the economics for a stand-alone DCH unit produced by UOP. Because of its lower reported capital cost, this re-refining technology appears to be more profitable than the vacuum distillation/hydrotreatment process. Additional capital cost reductions and yield improvements are possible if this unit is integrated into an existing lubricating oil refinery.

The Interline solvent extraction/vacuum distillation process is another option for integration into an existing lubricating oil refinery. The quality of the re-refined oil from the Interline process would not meet demanding motor oil specifications, but the product may be a good substitute feed to a lubricating oil hydrotreater, provided contaminants in the used oil do not deactivate the hydrogenation catalyst. The economics for this option are also summarized in Table 8.

Integration of the Interline process into a primary lubricating oil refinery does not appear profitable, on the basis of the assumptions used for this evaluation. Arguably, however, the Interline product would be valued higher than crude oil. This value would be added because the pre-treated feed would not need to undergo atmospheric and vacuum distillation, solvent extraction, and dewaxing processes, as crude oil would. One contact suggested that the internal value of the feedstock to a lubricating oil unit is as high as 60-70ф/gal (Sequeira 1994).

Other hurdles to re-refining in existing lubricating oil refineries may be collection, transportation, and stable supply of feedstock. For reference, the capacities of domestic lubricating oil refineries are provided in Table 10, and their locations are mapped in Figure 7. The volumes of lubricating oil sold in each state are also shown on the map. Although existing lubricating oil refineries are concentrated in only a few states (Texas, Louisiana, Indiana, California, Oklahoma, Pennsylvania, and Ohio), they are located at reasonable distances from areas expected to generate the greatest volumes of used oil. Possibly, the waste oil collection and transportation functions could be contracted to smaller, regional companies to minimize the overhead costs that large oil companies face when handling low-volume feedstocks. 
TABLE 10 Capacities of Domestic Lubricating Oil Refineries

\begin{tabular}{llr}
\hline \multicolumn{1}{c}{ Company } & \multicolumn{1}{c}{ City/State } & $\begin{array}{c}\text { Production Capacity } \\
\left(10^{6} \text { gal/yr }\right)\end{array}$ \\
\hline & & \\
Amoco Oil Co. & Whiting, Ind. & 94 \\
Ashland Petroleum Co. & Catlettsburg, Ky. & 126 \\
Atlas Processing Co., Div. of Pennzoil & Shreveport, La. & 117 \\
Calumet Lubricants Co. & Princeton, La. & 50 \\
Chevron U.S.A., Inc. & Richmond, Calif. & 190 \\
Citgo Petroleum Corp. & Lake Charles, La. & 124 \\
Cross Oil. \& Refining Co., Inc. & Smackover, Ark. & 54 \\
Diamond Shamrock Corp. & Three Rivers, Texas & 15 \\
Ergon Refining, Inc. & Vicksburg, Miss. & 100 \\
Exxon Co. U.S.A. & Baytown, Texas & 480 \\
Exxon Co. U.S.A. Refinery, Inc. & Baton Rouge, La. & 238 \\
Lyondell - Citgo Refining Co. & Houston, Texas & 100 \\
Mobil Oil Corp. & Paulsboro, N.J. & 126 \\
Mobil Oil Corp. & Beaumont, Texas & 155 \\
Pennzoil Products Co. & Rouseville, Penn. & 66 \\
Quaker State Oil Refining Corp. & Newell, W. Va. & 66 \\
San Joaquin Refining & Bakersfield, Calif. & 61 \\
Shell Oil Co. & Martinez, Calif. & 60 \\
Shell Oil Co. & Wood River, Ill. & 77 \\
Shell Oil Co. & Deer Park, Texas & 146 \\
Star Enterprise & Port Arthur, Texas & 269 \\
Sun Refining \& Marketing Co. & Tulsa, Okla. & 110 \\
Unocal Corp. & Pasadena, Calif. & 66 \\
Witco Corp. & Bradford, Penn. & 37 \\
Witco Corp., Golden Bear Div. & Oildale, Calif. & 74 \\
Young Refining Corp. & Douglasville, Ga. & 31 \\
\hline & & \\
\hline & &
\end{tabular}

Source: Oil and Gas Journal, December 20, 1993.

Research needs to promote the re-refinery integration option include developing and demonstrating re-refining technology integrated with a lubricating oil refinery; identifying used oil contaminants that deactivate hydrogenation catalysts; and, if needed, developing technology for their removal and/or developing more effective catalysts for this application. This research would best be conducted in partnership with the technology licensor (UOP, Interline, or other) and a major lubricating oil refiner. 


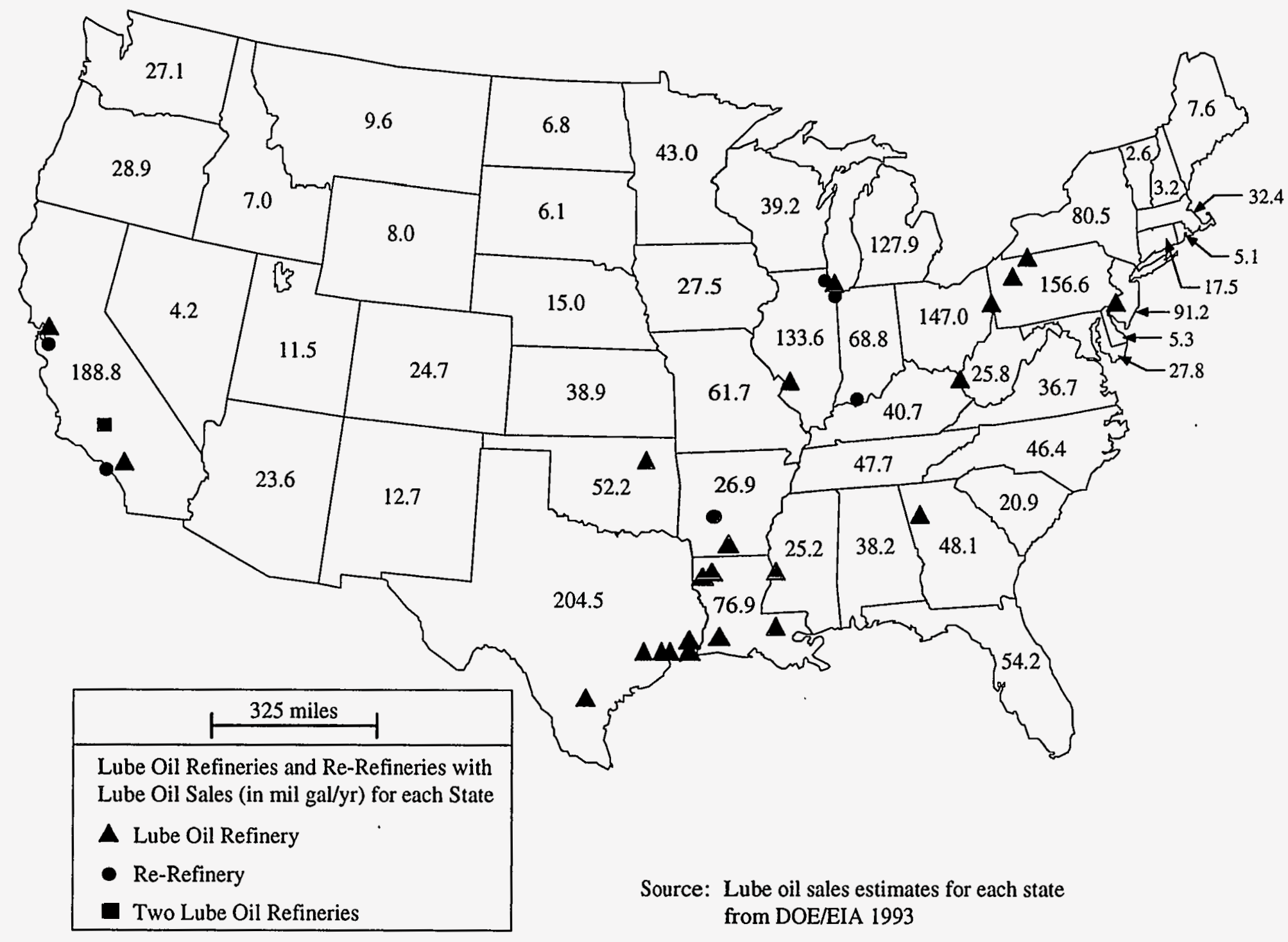

FIGURE 7 Domestic Lubricating Oil Refinery and Re-Refinery Locations 


\subsection{Reuse Hierarchy}

On the basis of our evaluations of energy, environment, and economics for each reuse option, we have developed the hierarchy shown in Figure 8. Source reduction offers the greatest potential for energy savings and reduced environmental impacts and is proposed as the priority strategy.

Because of the energy savings associated with multiple use, re-refining is ranked higher than other consumptive reuses. Re-refining in a lubricating oil refinery is ranked above re-refining in a dedicated unit because of the opportunities for capital cost reductions, increased yields, recovery of higher-value by-products, and more efficient pollution control. Also for these reasons, reprocessing in a primary refinery is ranked above reprocessing in dedicated equipment.

Reprocessing in dedicated equipment and burning in space heaters are ranked equally because we found no clear basis to rate the trade-offs. Burning in space heaters, when heat is needed, avoids the energy consumption and environmental impacts associated with transporting and reprocessing oil. However, the uncontrolled emissions from space heaters, particularly in populated areas, may be more harmful than burning reprocessed oil at an industrial site that may be equipped with pollution control equipment.

Finally, used oil disposal or dumping is the least desirable alternative because the energy value of the oil is lost and the oil can potentially contaminate groundwater and surface waters.

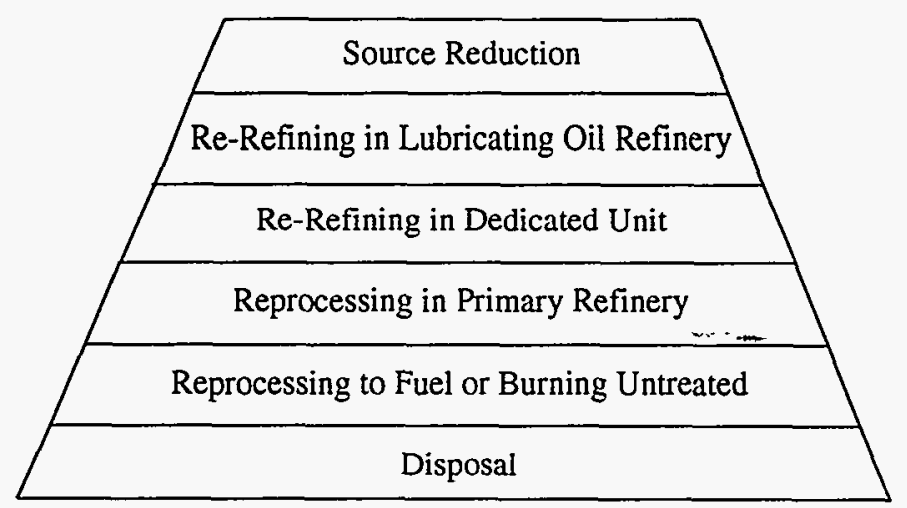

FIGURE 8 Hierarchy of Waste Oil Reuse Options 


\section{Summary}

The objective of this opportunity assessment was to highlight waste oil issues warranting future research. Generally, future efforts should target the following areas: (1) increasing the availability and effectiveness of collection programs for oil generated by DIY and off-road sources; (2) achieving lubricating oil source reduction, specifically in automotive motor oil applications; and (3) increasing the volume of re-refined oil manufactured and sold. To the extent feasible, research should be conducted cooperatively with lubricating oil formulators and manufacturers; industrial lubricating oil consumers (e.g., automobile, engine, and parts manufacturers); regulators; and used oil collectors, reprocessors, and re-refiners. 


\section{References}

Arnold, D., 1994, "Update on Federal Buy Recycled Policy," paper presented at the First International Congress on Liquid Waste Recycling, Liquid Assets, San Francisco, Calif., May 23-27, sponsored by the National Oil Recyclers Association and Association of Petroleum Re-Refiners.

Bider, W.L., 1985, Composition and Management of Used Oil Generated in the United States, EPA/530-SW-013, prepared for U.S. Environmental Protection Agency by Franklin Associates Ltd., Prairie Village, Kans.

Bosco, M., 1994, Waste Oil Heater Manufacturers Association, Washington, D.C., personal communication.

Brinkman, D.W., et al., 1981, Environmental, Resource Conservation, and Economic Aspects of Used Oil Recycling, DOE/BETC/RI-80/11, U.S. Department of Energy, Bartlesville Energy Technology Center, Okla.

Che, S., and R. Kessler, 1991, "Update of KTI RELUBE Process," Proceedings of the Sixth International Conference on Used Oil Recovery and Reuse, Re-Refining Rebirth, pp. 157-169, San Francisco, Calif., May 28-31, sponsored by the National Oil Recyclers Association and Association of Petroleum Re-Refiners.

Chu, Y., 1994, "Re-Refining Without the Use of Acid or Hydrogen," paper presented at the First International Congress on Liquid Waste Recycling, Liquid Assets, San Francisco, Calif., May 23-27, sponsored by the National Oil Recyclers Association and Association of Petroleum Re-Refiners.

Cooke, M., et al., 1984, Waste Crankcase Oil Heater Study: Phase II, Organic and Inorganic Speciation Analyses, EPA-600/7-84-072, U.S. Environmental Protection Agency, Research Triangle Park, N.C.

Dietly, K., 1992, "Perspectives on the Generation and Management of Used Oil in the U.S. in 1991," Clayton Environmental Consultants' presentation at the 1992 NORA Annual Meeting, Nov. 5, 1992, Scottsdale, Ariz.

Dish, D., 1994, Cincinnati Millicron, Cincinnati, Ohio, personal communication.

DOE/EIA, 1993, Energy Data Report 1991: Consumption Estimates, DOE/EIA-0214(91), U.S. Department of Energy. 
Döhring, K., 1994, Freudenberg-NOK, personal communication, May 2, 1994, and U.S. Patent 5, 107, 806, assigned April 28, 1992.

Elliot, D., 1993, Vermont Used Oil Analysis and Emissions Study, Vermont Agency of Natural Resources, Waterbury, Vt.

Entropy, Inc., 1994, Metals Emissions from the Combustion of Used Oil Fuel: Phase I, Literature Search and Survey, report prepared for Used Oil Recycling Coalition, Washington, D.C., by Entropy, Inc., Research Triangle Park, N.C.

EPA, 1989, How to Set Up a Local Program to Recycle Used Oil, EPA/530-SW-89-039A, U.S. Environmental Protection Agency, Washington, D.C.

Gaines, L.L., and A.M. Wolsky, 1981, Energy and Materials Flows in Petroleum Refining, ANL/CNSV-10, Argonne National Laboratory, Argonne, Ill.

Gary, J.H., and G.E. Handwerk, 1994, Petroleum Refining: Technology and Economics, Third Edition, Marcel Dekker, Inc., New York., N.Y.

Gottleib, M., 1981, Analysis of Potential Used-Oil Recovery from Individuals, DOE/BC/10053-21, prepared for U.S. Department of Energy, Bartlesville Energy Technology Center, Bartlesville, Okla., by Market Facts, Chicago, Ill.

Gressel, A., 1994, Research Environmental Industries, Cleveland, Ohio, personal communication.

Gressel, A., 1995, Research Environmental Industries, Cleveland, Ohio, personal communication.

Hall, R.E., M.W. Cooke, and R.L. Barbour, 1983, "Comparison of Air Pollutant Emissions from Vaporizing and Air Atomizing Waste Oil Heaters," Journal of the Air Pollution Control Association, Vol. 33, No. 7, pp. 683-687.

Hayes, T.L., 1992, Industry Study 450: Lubricants to 1996, The Freedonia Group, Inc., Cleveland, Ohio.

Hegberg, B.A., W.H. Hallenbeck, and G.R. Brenniman, 1991, Used Oil Management in Illinois, OTT-10, prepared for Illinois Department of Energy and Natural Resources, Springficld, Ill.

Hill, S.H., and S.J. Sytsma, 1991, "A Systems Approach to Oil Consumption," paper presented at the Society of Automotive Engineers International Congress and Exposition, Detroit, Mich., Feb. 25-March 1. 
HPI Consultants, 1987, Crude Oil Assay Handbook, First Edition.

Hunt, T.M., 1985, "Contamination and Viscosity Monitoring of Automobile and Motor Cycle Oils Using a Portable Contamination Meter," Institution of Mechanical Engineers C37/85, pp. 41-48.

Kalnes, T.N., et al., 1989, "Recycling Waste Lube Oils for Profit (UOP Direct Contact Hydrogenation Process)," Hazardous Waste \& Hazardous Materials, Vol. 6, No. 1, pp. 51-66.

Kalnes, T.N., et al., 1990, "Treatment and Recycle of Waste Lubricants: A Petroleum Refinery Integration Study," paper presented at the American Institute of Chemical Engineers' Summer National Meeting, San Diego, Calif., Aug. 19-22.

Kenton, K., and J. Hedberg, 1994, "The Vaxon Re-Refining Process," paper presented at the First International Congress on Liquid Waste Recycling, Liquid Assets, San Francisco, Calif., May 23-27, sponsored by the National Oil Recyclers Association and Association of Petroleum Re-Refiners.

Lee, R.S., 1995, Automotive Oil Change Association, Dallas, Texas, personal communication.

Loveton, R.F., 1994, Full Prime System, Inc., Penn Valley, Calif., personal communication.

Magnabosco, L., M. Falconer, and K. Padmanabhan, 1991, "The Mohawk/CEP Re-Refining Process," Proceedings of the Sixth International Conference on Used Oil Recovery and Reuse, Re-Refining Rebirth, pp. 143-155, San Francisco, Calif.

Maples, R.E., 1993, Petroleum Refinery Process Economics, PennWell Publishing Company, Tulsa, Okla.

McKeagan, D.J., 1992, "Economics of Re-Refining Used Lubricants," Lubrication Engineering, pp. 418-423.

Meyers, R.A., 1986, Handbook of Petroleum Refining Processes, McGraw-Hill, Inc., New York, N.Y.

Morgan, C.A., 1994, Interline Resources Corporation, Alpine, Utah, personal communication (and company literature).

Morishita, S., et al., 1993, "Development of an On-Board Type Oil Deterioration Sensor," paper presented at the Society of Automotive Engineers Fuels and Lubricants Mecting and Exposition, Philadelphia, Penn., Oct. 18-21. 
Mueller Associates, Inc., 1989, Waste Oil: Reclaiming Technology, Utilization and Disposal, Noyes Data Corporation, Park Ridge, N.J.

Needelman, W. N., 1994, "Filtration," CRC Handbook of Lubrication and Tribology, Volume III, CRC Press, Inc., Boca Raton, Fla., pp. 71-87.

Nelson, W.L., 1976, Guide to Refinery Operating Costs, Third Edition, The Petroleum Publishing Company, Tulsa, Okla.

Nolan, J.J., C. Harris, and P.O. Cavanaugh, 1990, Used Oil: Disposal Options, Management Practices and Potential Liability, Third Edition, Government Institutes, Inc.

Porter, M., 1994, Partek Corporation, Vancouver, Wash., personal communication.

Prather, J.W., J.A. Guin, and A.R. Tarrer, 1979, "X-Ray Fluorescence Analysis of Trace Elements in Coal and Solvent Refined Coal," Chapter 49, pp. 357-369, of Analytical Methods for Coal and Coal Products, Volume III, edited by Clarence Karr, Jr., Academic Press, New York, N.Y.

Recon Systems, Inc., 1980, Used Oil Burned as a Fuel, Volume I, SW-892, prepared for U.S. Environmental Protection Agency, Washington, D.C., by Recon Systems, Inc., Princeton, N.J.

Schieppati, R., 1991, "Waste Oil Thermal Deasphalting," Proceedings of the Sixth International Conference on Used Oil Recovery and Reuse, Re-Refining Rebirth, pp. 133-142, San Francisco, Calif., May 28-31.

Schieppati, R., and D. Giovanna, 1994, "Update of the Improvements to the AGIP/VISCOLUBE Technology," paper presented at the First International Congress on Liquid Waste Recycling, Liquid Assets, San Francisco, Calif., May 23-27, sponsored by the National Oil Recyclers Association and Association of Petroleum Re-Refiners.

Schwartz, S.E., and D.J. Smolenski, 1987, "Development of an Automatic Engine Oil-Change Indicator System," paper presented at the Society of Automotive Engineers International Congress and Exposition, Detroit, Mich., Feb. 23-27.

Sen, J., and W.E. VanArsdale, 1992, "Condition Monitoring of Oil in a Single Cylinder Engine," paper presented at the Society of Automotive Engineers International Fuels and Lubricants Meeting and Exposition, San Francisco, Calif., Oct. 19-22.

Sequeira, A. Jr., 1994, personal communication. 
Sorab, J., and W.E. VanArsdale, W.E., 1990, "Condition Monitoring of Engine Oils," paper presented at the Society of Automotive Engineers International Fuels and Lubricants Meeting and Exposition, Tulsa, Okla., Oct. 22-25.

Stitzel, D., 1992, A Guidebook for Implementing Curbside and Drop-Off Used Motor Oil Collection Programs, prepared for the American Petroleum Institute by the Washington Citizens for Recycling Foundation, Seattle, Wash.

Strathorn, D.F., 1991, "Used Oil Re-refining Process Discussion," Proceedings of the Sixth International Conference on Used Oil Recovery and Reuse, Re-Refining Rebirth, pp. 171-177, San Francisco, Calif., May 28-31.

Surprenant, N.F., W.H. Battye, and P.F. Fennelly, 1983, The Fate of Hazardous and Nonhazardous Wastes in Used-Oil Disposal and Recycling, DOE/BC/10375-6, prepared for U.S. Department of Energy, Bartlesville Energy Technology Center, Bartlesville, Okla., by GCA Corporation, Bedford, Mass.

Swager, R., S. Al-Basha, and R. Kraft, 1993, Recommendations for a Used Oil Recovery Program in Illinois, ILENR/RR-92/11, Illinois Department of Energy and Natural Resources, Springfield, Ill.

Talbot, C. J., et al., 1990, “An Innovative Graduate Thesis: A Team Evaluation of Used Oil End Uses, the Environmental Challenge of the 1990s," Proceedings from the International Conference on Pollution Prevention, Clean Technologies and Clean Products, Washington, D.C.

Talbot, J.S., editor, 1992, Guide to Used Oil Regulations, Thompson Publishing Group, Washington, D.C. (1992, with monthly updates through May 1995).

Taylor, P., 1986, "Operating Lube Oil Plants Efficiently," paper presented at American Institute of Chemical Engineers' National Meeting, New Orleans, La.

Thompson, C.J., and D.W. Brinkman, 1981, "Energy Saving by Re-Refining Used Oils," Commission of the European Communities, European Commission for Regeneration, Recycling of Used Oils, D. Reidel Publishing Company, pp. 253-266.

Troy, K., 1989, Preliminary Data Summary for the Used Oil Reclamation and Re-Refining Industry, EPA 440/1-89/014, U.S. Environmental Protection Agency, Washington, D.C.

U.S. Department of Energy/Energy Information Administration: see DOE/EIA

U.S. Environmental Protection Agency: see EPA. 
Vermont Agency of Natural Resources, 1994, Vermont Used Oil Analysis and Waste Oil Furnace Emissions Study, Waterbury, Vt.

Walker, W.B., 1981, "Pollution of the Environment by the Burning of Waste Oils," Commission of the European Communities, European Commission for Regeneration, Recycling of Used Oils, D. Reidel Publishing Company, pp. 275-289.

Warren, T.J., 1994, "Developing Infrastructure to Recycle Oil Filters in the U.S.," paper presented at the First International Congress on Liquid Waste Recycling, Liquid Assets, San Francisco, Calif., sponsored by the National Oil Recyclers Association and Association of Petroleum Re-Refiners; also Warren, T.J., Allied Signal Automotive, East Providence, R.I., personal communication.

Weinstein, N.J., 1974, Waste Oil Recycling and Disposal, EPA-670/2-74-052, prepared for U.S. Environmental Protection Agency by Recon Systems, Inc., Princeton, N.J.

Wolf, D., 1994, Clean Burn, Inc., Leola, Penn., personal communication.

Wulfers, T.F., 1994, Lyondell Lubricants, Houston, Texas, personal communication.

Zakarian, J.A., R.J. Robson, and T.R. Farrell, 1987, "All-Hydroprocessing Route for HighViscosity Index Lubes,” Energy Progress, Vol. 7, No. 1, pp. 59-64. 
Appendix A:

State Waste Oil Regulations and Incentives 
$\ldots+\ldots$ 
TABLE A.1 State Waste Oil Regulations

\begin{tabular}{|c|c|c|c|c|c|}
\hline State & General Comments & Disposal Bans & Other Stringent Requirements & Fees or Taxes & Used Oil Filters \\
\hline Alabama & $\begin{array}{l}\text { Used oil destined for recycling or energy recovery } \\
\text { not regulated as hazardous waste. } \\
\text { Used oil mixed with hazardous waste or destined } \\
\text { for disposal regulated as hazardous waste. }\end{array}$ & $\begin{array}{l}\text { No liquids allowed in landfills. } \\
\text { Use as road oil, dust } \\
\text { suppressant, or weed killer } \\
\text { prohibited. }\end{array}$ & $\begin{array}{l}\text { Stricter storage requirements (e.g. } \\
\text { stipulated minimum capacity and } \\
\text { precipitation control for secondary } \\
\text { containment, and removal and } \\
\text { decontamination procedures at } \\
\text { closure.) }\end{array}$ & & \\
\hline Alaska & $\begin{array}{l}\text { Used oil destined for recycling or energy recovery } \\
\text { not regulated as hazardous waste. } \\
\text { Used oil mixed with hazardous waste or destined } \\
\text { for disposal regulated as hazardous waste. }\end{array}$ & No liquids allowed in landfills. & $\begin{array}{l}\text { Mandate that commercial water } \\
\text { vessels be equipped with a place to } \\
\text { deposit used oils. }\end{array}$ & $\begin{array}{l}\text { Proposed for future } \\
\text { discussion. }\end{array}$ & \\
\hline Arizona & $\begin{array}{l}\text { Used oil destined for recycling or energy recovery } \\
\text { not regulated as hazardous waste. } \\
\text { Used oil mixed with hazardous waste or destined } \\
\text { for disposal regulated as hazardous waste. }\end{array}$ & $\begin{array}{l}\text { Disposal in sewers or waters, } \\
\text { on land, or by incineration } \\
\text { allowed only if } \\
\text { permitted/authorized. }\end{array}$ & $\begin{array}{l}\text { Recycle does not include buming of } \\
\text { used oil as fuel. }\end{array}$ & $\begin{array}{l}6 \notin / g a l \text { tax on } \\
\text { buming of on-spec } \\
\text { oil; } 204 / \text { gal tax on } \\
\text { buming of oft-spec } \\
\text { oil. }\end{array}$ & \\
\hline Arkansas & $\begin{array}{l}\text { Used oil destined for recycling or energy recovery } \\
\text { not regulated as hazardous waste. } \\
\text { Used oil mixed with hazardous waste or destined } \\
\text { for disposal regulated as hazardous waste. }\end{array}$ & $\begin{array}{l}\text { Provision adopted to permit } \\
\text { application as dust } \\
\text { suppressant under stringent } \\
\text { restrictions. }\end{array}$ & $\begin{array}{l}\text { Processors and re-refiners required } \\
\text { to submit annual used oil activity } \\
\text { reports. }\end{array}$ & & $\begin{array}{l}\text { Procedures for disposal } \\
\text { recommended. }\end{array}$ \\
\hline California & $\begin{array}{l}\text { Used oil regulated as hazardous waste until it } \\
\text { meets state-established purity standards. } \\
\text { Certified sites that collect DIY oil are exempt } \\
\text { from most hazardous waste requirements. }\end{array}$ & $\begin{array}{l}\text { Disposal in sewers or waters, } \\
\text { on land, or by incineration } \\
\text { allowed only if } \\
\text { permilted/authorized. Dust } \\
\text { suppressant, herbicide, and } \\
\text { road oil applications } \\
\text { restricted. }\end{array}$ & $\begin{array}{l}\text { Stricter "purity standards," } \\
\text { including: lead less than } 50 \mathrm{ppm} \text {, } \\
\text { halogens less than } 1,000 \mathrm{ppm} \text {. } \\
\text { Certification, recordkeeping, and } \\
\text { reporting requirements. }\end{array}$ & $\begin{array}{l}16 \notin / g a l \text { tax on oils } \\
\text { sold in state. }\end{array}$ & \\
\hline Colorado & $\begin{array}{l}\text { Used oll destined for recycling or energy recovery } \\
\text { not regulated as hazandous waste. } \\
\text { Used oil mixed with hazandous waste or destined } \\
\text { for disposal regulated as hazardous waste. }\end{array}$ & $\begin{array}{l}\text { Land disposal or use as dust } \\
\text { suppressant or we日d killer } \\
\text { prohibited. }\end{array}$ & & & \\
\hline Connecticut & $\begin{array}{l}\text { Used oll destined for recycling or energy recovery } \\
\text { not regulated as hazardous waste. } \\
\text { Used oil mixed with hazardous waste or destined } \\
\text { for disposal regulated as hazardous waste. }\end{array}$ & $\begin{array}{l}\text { Landfilling and incineration } \\
\text { prohibited. }\end{array}$ & $\begin{array}{l}\text { Burning of used oil in residential } \\
\text { boilers prohibited. Permit } \\
\text { requirements for transporters and } \\
\text { marketers. Marketers must have } \\
\text { written waste analysis plan. }\end{array}$ & $\begin{array}{l}\text { Waste oil treaters } \\
\text { pay } \$ 14,000 \text { fee } \\
\text { for five-year } \\
\text { permit. } \$ 500 \\
\text { annual permit fee } \\
\text { for transporters. }\end{array}$ & $\begin{array}{l}\text { Procedures for disposal } \\
\text { recommended. }\end{array}$ \\
\hline
\end{tabular}


TABLE A.1 (Cont.)

\begin{tabular}{|c|c|c|c|c|c|}
\hline State & General Comments & Disposal Bans & Olher Stringent Requirements & Fees or Taxes & Used Oil Filters \\
\hline Delaware & $\begin{array}{l}\text { Used oil destined for recycling or energy recovery } \\
\text { not regulated as hazardous waste. } \\
\text { Used oil mixed with hazardous waste or destined } \\
\text { for disposal regulated as hazardous waste. }\end{array}$ & $\begin{array}{l}\text { Landfill disposal or use as } \\
\text { road oil, dust suppressant, or } \\
\text { weed killer prohibited. }\end{array}$ & & $\begin{array}{l}\$ 300 / y r \text { permit } \\
\text { fee for used oil } \\
\text { transporters. }\end{array}$ & \\
\hline D.C. & $\begin{array}{l}\text { Used oil destined for recycling or energy recovery } \\
\text { not regulated as hazardous waste. } \\
\text { Used oil mixed with hazardous waste or destined } \\
\text { for disposal regulated as hazardous waste. }\end{array}$ & $\begin{array}{l}\text { Use for dust suppression or } \\
\text { road oll, and discharge into } \\
\text { sewers prohibited. }\end{array}$ & & & \\
\hline Florida & $\begin{array}{l}\text { Used oil destined for recycling or energy recovery } \\
\text { not regulated as hazardous waste. } \\
\text { Used oil mixed with hazardous waste or destined } \\
\text { for disposal regulated as hazardous waste. }\end{array}$ & $\begin{array}{l}\text { Solid waste landfill disposal; } \\
\text { discharge into sewers or } \\
\text { waters; and use as road oil, } \\
\text { dust suppressant, or weed } \\
\text { killer prohibited. }\end{array}$ & $\begin{array}{l}\text { Transporters, collectors, and } \\
\text { recyclers required to register with } \\
\text { state. Recordkeeping and reporting } \\
\text { requirements associated with } \\
\text { registration. }\end{array}$ & $\begin{array}{l}\$ 100 \text { registration } \\
\text { fee for recyclers, } \\
\text { transporters, } \\
\text { marketers, and } \\
\text { burners of off-spec } \\
\text { fuel. }\end{array}$ & $\begin{array}{l}\text { Excluding households, oll } \\
\text { filters cannot be } \\
\text { disposed of in landfill. } \\
\text { Filter generators, } \\
\text { transporters, and } \\
\text { processors must } \\
\text { register with state. }\end{array}$ \\
\hline Georgia & $\begin{array}{l}\text { Used oil destined lor recycling or energy recovery } \\
\text { not regulated as hazardous waste. } \\
\text { Used oil mixed with hazardous waste or destined } \\
\text { for disposal regulated as hazardous waste. }\end{array}$ & $\begin{array}{l}\text { Use for road oil, dust } \\
\text { suppressant, or weed killer } \\
\text { prohibited. Landfill disposal } \\
\text { allowed under limited } \\
\text { circumstances. }\end{array}$ & & & \\
\hline Hawaii & $\begin{array}{l}\text { Used oil destined for recycling or energy recovery } \\
\text { not regulated as hazardous waste. } \\
\text { Used oil mixed with hazardous waste or destined } \\
\text { for disposal regulated as hazardous waste. }\end{array}$ & $\begin{array}{l}\text { Discharge into sewers, } \\
\text { waters, or on ground } \\
\text { prohibited. }\end{array}$ & $\begin{array}{l}\text { State permits and recordkeeping } \\
\text { required for transporters, recyclers, } \\
\text { burners, and marketers. }\end{array}$ & & \\
\hline Idaho & $\begin{array}{l}\text { Used oil destined for recycling or energy recovery } \\
\text { not regulated as hazardous waste. } \\
\text { Used oil mixed with hazardous waste or destined } \\
\text { for disposal regulated as hazardous waste. }\end{array}$ & $\begin{array}{l}\text { No landtill disposal unless it } \\
\text { is the "only reasonable } \\
\text { altemative." Road oil and dust } \\
\text { suppressant applications } \\
\text { restricted. }\end{array}$ & & & \\
\hline Illinois & $\begin{array}{l}\text { Used oil regulated as "special waste" includes } \\
\text { hazardous waste that could pose threats to } \\
\text { human health or to environment. } \\
\text { Used oil destined for disposal is regulated as }\end{array}$ & $\begin{array}{l}\text { Landfill disposal or use as } \\
\text { road oil, dust suppressant, or } \\
\text { weed killer prohibited. }\end{array}$ & $\begin{array}{l}\text { State "special waste" permits } \\
\text { required for transporters, burners, } \\
\text { and recyclers. }\end{array}$ & & \\
\hline
\end{tabular}

Used oil destined for disposal is regulated as hazardous waste. 
TABLE A.1 (Cont.)

\begin{tabular}{|c|c|c|c|c|c|}
\hline Stale & General Comments & Disposal Bans & Other Stringent Requirements & Fees or Taxes & Used Oll Filters \\
\hline Indiana & $\begin{array}{l}\text { Used oil destined for recycling or energy recovery } \\
\text { not regulated as hazardous waste } \\
\text { Used oil mixed with hazardous waste or destined } \\
\text { for disposal regulated as hazardous waste }\end{array}$ & $\begin{array}{l}\text { Solid waste landfill disposal, } \\
\text { and use as road oil or dust } \\
\text { suppressant prohibited. }\end{array}$ & & . & \\
\hline lowa & $\begin{array}{l}\text { Used oil destined for recycling or energy recovery } \\
\text { not regulated as hazardous waste. } \\
\text { Used oil mixed with hazardous waste or destined } \\
\text { for disposal regulated as hazardous waste. }\end{array}$ & $\begin{array}{l}\text { Sanitary landfill disposal; } \\
\text { discharge into state } \\
\text { waterways; and use as road } \\
\text { oil, dust suppressant, or weed } \\
\text { killer prohibited. }\end{array}$ & $\begin{array}{l}\text { Motor oil retailers must list location } \\
\text { of nearest collection site. State sets } \\
\text { standards for collection sites, } \\
\text { including supervision requirements. }\end{array}$ & & \\
\hline Kansas & $\begin{array}{l}\text { Used oil destined for recycling or energy recovery } \\
\text { not regulated as hazardous waste. } \\
\text { Used oil mixed with hazardous waste or destined } \\
\text { for disposal regulated as hazardous waste. }\end{array}$ & $\begin{array}{l}\text { Landfill disposal, and use as } \\
\text { road oil or dust suppressant } \\
\text { prohibited. }\end{array}$ & $\begin{array}{l}\text { Registration for transporters. } \\
\text { Recyclers must be permitted. } \\
\text { Generators (greater than } \\
500 \text { gals/yr) required to accept DIY } \\
\text { oil. Retailers must post locations of } \\
\text { nearest coilection site. }\end{array}$ & & \\
\hline Kentucky & $\begin{array}{l}\text { Used oil destined for recycling or energy recovery } \\
\text { not regulated as hazardous waste. } \\
\text { Used oil mixed with hazardous waste or destined } \\
\text { for disposal regulated as hazardous waste. }\end{array}$ & $\begin{array}{l}\text { Discharge into sewers or } \\
\text { waters and incineration other } \\
\text { than for energy recovery } \\
\text { prohibited. Use for dust } \\
\text { suppression or road olling } \\
\text { allowed only if oil does not } \\
\text { have hazardous } \\
\text { characteristics. }\end{array}$ & $\begin{array}{l}\text { Registration, recordkeeping, and } \\
\text { reporting requirements for used oll } \\
\text { transporters, storage facilities, and } \\
\text { recyclers. Oil retailers required to } \\
\text { post locations of collection sites. }\end{array}$ & $\begin{array}{l}\text { Annual } \$ 300 \\
\text { registration fee for } \\
\text { marketers and } \\
\text { burners. }\end{array}$ & \\
\hline Louisiana & $\begin{array}{l}\text { Used oll destined for recycling or energy recovery } \\
\text { not regulated as hazardous waste. } \\
\text { Used oil mixed with hazardous waste or destined } \\
\text { for disposal regulated as hazardous waste. }\end{array}$ & $\begin{array}{l}\text { Solid waste landfill disposal; } \\
\text { discharge into sewers or } \\
\text { waters; and use as road oil, } \\
\text { dust suppressant, or weed } \\
\text { killer prohibited. }\end{array}$ & & & \\
\hline
\end{tabular}


TABLE A.1 (Cont.)

\begin{tabular}{|c|c|c|c|}
\hline State & General Comments & Disposal Bans & Other Stringent Requirements \\
\hline Maine & $\begin{array}{l}\text { Used oil destined for recycling or energy recovery } \\
\text { not regulated as hazardous waste. } \\
\text { Used oil mixed with hazardous waste or destined } \\
\text { for disposal regulated as hazardous waste. }\end{array}$ & $\begin{array}{l}\text { Landfill disposal and use as } \\
\text { road oil, dust suppressant, or } \\
\text { weed killer prohibited. }\end{array}$ & $\begin{array}{l}\text { License requirements include } \\
\text { liability insurance, recordkeeping, } \\
\text { inspection, and training. Waste oil } \\
\text { storage tacilities subject to } \\
\text { rebultable presumption, restricting } \\
\text { locations in certain high-risk areas. }\end{array}$ \\
\hline Maryland & $\begin{array}{l}\text { Used oil destined for recycling or energy recovery } \\
\text { not regulated as hazardous waste. } \\
\text { Used oil mixed with hazardous waste or destined } \\
\text { for disposal regulated as hazardous waste. }\end{array}$ & $\begin{array}{l}\text { Discharge into sewers, } \\
\text { waters, or land and } \\
\text { incineration prohibited. }\end{array}$ & $\begin{array}{l}\text { Motor oil retailers required to post } \\
\text { locations of collection sites. All } \\
\text { persons prohibited from knowingly } \\
\text { adding any liquid or solid substance } \\
\text { to used oil. Closure and secondary } \\
\text { containment requirements apply for } \\
\text { used oil handlers. }\end{array}$ \\
\hline
\end{tabular}

Massachusetts Used oil regulated as hazardous waste.

\section{Michigan}

\section{Minnesota}

Mississippi
Used oil destined for recycling or energy recovery not regulated as hazardous waste.

Used oil mixed with hazardous waste or destined

for disposal regulated as hazardous waste.

Used oil destined for recycling or energy recovery not regulated as hazardous waste.

Used oil mixed with hazardous waste or destined

for disposal regulated as hazardous waste.

Used oil destined for recycling or energy recovery not regulated as hazardous waste.

Used oil mixed with hazardous waste or destined

for disposal regulated as hazardous waste.
Use for road oil, dust suppressant, or weed killer prohibited.

Landfill disposal, discharge into sewers or waters, and municipal solid waste incineration prohibited.

Used oil prohibited from mixed municipal solid waste. Use for road oil or dust suppressant prohibited.

Use as dust suppressant or weed killer prohibited.
Fees or Taxes

Used Oil Filters

$\$ 1,500$ application

and $\$ 500 / y r$

renewal fees for

waste oil storage

facility license;

$\$ 100 / y r$ fee for

transporter

license; \$.02/gal

fee to transport

waste into state

tc/gal fee to

collect oil in state.

Motor oil retailers required to

DIY collectors

exempted.

Bonding and licensing required for

transporters, bumers, and recyclers

of "liquid industrial wastes."

Motor oil retailers required to post

locations of collection sites.

Industrial generators required to

report activities.

Disposal of used oil

filters with municipal

solid waste prohibited. 
TABLE A.1 (Cont.)

\begin{tabular}{|c|c|c|c|c|c|}
\hline State & General Comments & Disposal Bans & Other Stringent Requirements & Fees or Taxes & Used Oil Fillers \\
\hline Missouri & $\begin{array}{l}\text { Used oil destined for recycling or energy recovery } \\
\text { not regulated as hazardous waste. } \\
\text { Used oil mixed with hazardous waste or destined } \\
\text { for disposal regulated as hazardous waste. }\end{array}$ & $\begin{array}{l}\text { Solid waste landfill disposal, } \\
\text { discharge to environment, or } \\
\text { use as road oil or dust } \\
\text { suppressant prohibited. }\end{array}$ & $\begin{array}{l}\text { Secondary containment required at } \\
\text { transfer facilities, recyclers, and } \\
\text { off-spec oil bumers with capacities } \\
\text { greater than } 10 \% \text { of waste volume. } \\
\text { Waste oil containing } 2-50 \text { ppm PCBs } \\
\text { assigned special state waste code. }\end{array}$ & & \\
\hline Montana & $\begin{array}{l}\text { Used oil destined for recycling or energy recovery } \\
\text { not regulated as hazardous waste. } \\
\text { Used oil mixed with hazardous waste or destined } \\
\text { for disposal regulated as hazardous waste. }\end{array}$ & $\begin{array}{l}\text { Disposal of free liquids in } \\
\text { landills prohibited. Dust } \\
\text { suppression prohibited } \\
\text { except for household DIY oil } \\
\text { changers and farmers. }\end{array}$ & $\begin{array}{l}\text { Motor oil retallers required to post } \\
\text { locations of collection sites. }\end{array}$ & & \\
\hline Nebraska & $\begin{array}{l}\text { Used oil destined for recycling or energy recovery. } \\
\text { not regulated as hazandous waste. } \\
\text { Used oil mixed with hazardous waste or destined } \\
\text { for disposal regulated as hazardous waste. }\end{array}$ & $\begin{array}{l}\text { Use for dust suppression or } \\
\text { road oil prohibited. Complete } \\
\text { ban on land application under } \\
\text { consideration. }\end{array}$ & & & \\
\hline Nevada & $\begin{array}{l}\text { Used oil destined for recycling or energy recovery } \\
\text { not regulated as hazardous waste. } \\
\text { Used oil mixed with hazardous waste or destined } \\
\text { for disposal regulated as hazardous waste. }\end{array}$ & $\begin{array}{l}\text { Disposal in sanitary landfill or } \\
\text { other unpermitted disposal } \\
\text { site, and use as dust } \\
\text { suppressant or weed killer } \\
\text { prohibited. }\end{array}$ & $\begin{array}{l}\text { Only conditionally exempt, small- } \\
\text { quantity generators permitted, with } \\
\text { recordkeeping, to mix ignitable } \\
\text { characteristic hazardous waste with } \\
\text { used oil. }\end{array}$ & $\cdot$ & \\
\hline $\begin{array}{l}\text { New } \\
\text { Hampshire }\end{array}$ & $\begin{array}{l}\text { Used oll always classified as hazardous waste. } \\
\text { Used oils recycled or burned for energy recovery } \\
\text { subject to less stringent standards. }\end{array}$ & $\begin{array}{l}\text { Use for road oil or dust } \\
\text { suppressant, and mixing for } \\
\text { use as automotive } \\
\text { undercoating prohibited. }\end{array}$ & $\begin{array}{l}\text { State-specified standards on } \\
\text { composition of "olf-spec used oil" } \\
\text { fuel. }\end{array}$ & $\begin{array}{l}4 \phi / g a l \text { fee on new } \\
\text { automotive } \\
\text { lubricating oil } \\
\text { imported into state } \\
\text { to fund municipal } \\
\text { grant program. }\end{array}$ & \\
\hline New Jersey & Used oil regulated as hazardous waste. & $\begin{array}{l}\text { Landfill disposal and use as } \\
\text { dust suppressant or weed } \\
\text { killer prohibited. }\end{array}$ & $\begin{array}{l}\text { Motor oil must be clearly labeled as } \\
\text { containing recyclable material. } \\
\text { Used oil regulated as hazardous } \\
\text { waste. }\end{array}$ & & \\
\hline New Mexico & $\begin{array}{l}\text { Used oil destined for recycling or energy recovery } \\
\text { not regulated as hazardous waste. } \\
\text { Used oil mixed with hazardous waste or destined } \\
\text { for disposal regulated as hazardous waste. }\end{array}$ & $\begin{array}{l}\text { Landfill disposal of free } \\
\text { liquids prohibited. Used oil } \\
\text { with hazardous } \\
\text { characteristics banned from } \\
\text { use as road oil or dust } \\
\text { suppressant. }\end{array}$ & & $\begin{array}{l}1 \phi / \mathrm{lb} / \mathrm{yr} \text { fe日 for } \\
\text { used oil destined } \\
\text { for disposal as } \\
\text { hazardous waste. }\end{array}$ & \\
\hline
\end{tabular}


TABLE A.1 (Cont.)

\begin{tabular}{|c|c|c|c|c|c|}
\hline State & General Comments & Disposal Bans & Other Stringent Requirements & Fees or Taxes & Used Oil Fillers \\
\hline New York & $\begin{array}{l}\text { Used oil destined for recycling or energy recovery } \\
\text { not regulated as hazardous waste. } \\
\text { Used oil mixed with hazardous waste or destined } \\
\text { for disposal regulated as hazardous waste. }\end{array}$ & $\begin{array}{l}\text { Landfill disposal and use as } \\
\text { road oil, dust suppressant, or } \\
\text { weed killer prohibited. }\end{array}$ & $\begin{array}{l}\text { Motor oil retailers and service } \\
\text { establishments required to accept } \\
\text { used oil at no charge. }\end{array}$ & $\begin{array}{l}10 \notin / q u a r t \text { fee on } \\
\text { lubricating oil } \\
\text { sales. }\end{array}$ & \\
\hline $\begin{array}{l}\text { North } \\
\text { Carolina }\end{array}$ & $\begin{array}{l}\text { Used oil destined for recycling or energy recovery } \\
\text { not regulated as hazardous waste. } \\
\text { Used oil mixed with hazardous waste or destined } \\
\text { for disposal regulated as hazardous waste. }\end{array}$ & $\begin{array}{l}\text { Landfill disposal; discharge } \\
\text { into sewers or waters; and } \\
\text { use as road oil, dust } \\
\text { suppressant, or weed killer } \\
\text { prohibited. }\end{array}$ & $\begin{array}{l}\text { Registration and reporting } \\
\text { requirements for collectors, } \\
\text { transporters, and recyclers. }\end{array}$ & $\begin{array}{l}\text { Collection facilities } \\
\text { that receive } \\
\text { greater than } \\
6,000 \mathrm{gal} / \mathrm{yr} \text { used } \\
\text { oil, transporters, } \\
\text { and recyclers pay } \\
\$ 25 / y r \\
\text { registration fee. }\end{array}$ & \\
\hline North Dakota & $\begin{array}{l}\text { Used oil destined for recycling or energy recovery } \\
\text { not regulated as hazardous waste. } \\
\text { Used oil mixed with hazardous waste or destined } \\
\text { for disposal regulated as hazardous waste. }\end{array}$ & $\begin{array}{l}\text { Landfill disposal and use as } \\
\text { road oil, dust suppressant, or } \\
\text { weed killer prohibited. }\end{array}$ & & $\begin{array}{l}\$ 75 \text { fee for waste } \\
\text { hauling permit; } \\
\$ 5,000 \text { permit fee } \\
\text { for resource } \\
\text { recovery facilities. }\end{array}$ & \\
\hline
\end{tabular}

Ohio Used oil regulated as solid waste.

Used oil destined for disposal must be tested to determine whether it is hazardous or ordinary solid waste.

Oklahoma Used oil is classified as a non-hazandous solid waste.

Used oil destined for disposal must be tested for hazardous characteristics; if positive, it must be managed as hazardous waste.

Oregon Used oil destined for recycling or energy recovery considered a recyclable material exempt from hazardous waste regulation.

Used oil mixed with hazardous waste or destined for disposal regulated as hazardous waste.

Pennsylvania Waste oil regulated under state hazardous waste regulations, with some exemptions.

Exempted waste oils are regulated as "residual waste."

Use as dust suppressant or road oil prohibited.

Landfill disposal; discharge into sewers or waters; and use as dust suppressant weed killer, or pesticide prohibited.

Used oil must be recycled or deposited in a used oil collection site. Disposal in sewers, waters, or onto land prohibited.
Motor oil retailers required to post locations of collection sites.

Residues from used oil burning classitied as hazardous waste. Annual reporting required for used oil processors. Solvent burning in waste oil space heaters prohibited.

Stricter parameters for offspecificalion oil. Permitting and reporting required for collectors, transporters, and recyclers. 
TABLE A.1 (Cont.)

\begin{tabular}{|c|c|c|c|c|c|}
\hline State & General Comments & Disposal Bans & Other Stringent Requirements & Fees or Taxes & Used Oil Filters \\
\hline Rhode Island & Used oil regulated as hazardous waste. & $\begin{array}{l}\text { Disposal in sewers, waters, } \\
\text { on land or by incineration only } \\
\text { in accordance with } \\
\text { regulations. }\end{array}$ & $\begin{array}{l}\text { Used oil regulated as hazardous } \\
\text { waste. Information posting } \\
\text { requirements for motor oil retailers. }\end{array}$ & $\begin{array}{l}\text { 54/quart motor oll } \\
\text { tax. }\end{array}$ & $\begin{array}{l}\text { Filters must be sent to } \\
\text { recyclers that recycle } \\
90 \% \text { of parts. }\end{array}$ \\
\hline $\begin{array}{l}\text { South } \\
\text { Carolina }\end{array}$ & $\begin{array}{l}\text { Used oil destined for recycling or energy recovery } \\
\text { not regulated as hazardous waste. } \\
\text { Used oil mixed with hazardous waste or destined } \\
\text { for disposal regulated as hazardous waste. }\end{array}$ & $\begin{array}{l}\text { Landfill disposal; discharge in } \\
\text { sewers or waters; and use as } \\
\text { road oil, dust suppressant, or } \\
\text { weed killer prohibited. }\end{array}$ & $\begin{array}{l}\text { Registration and reporting } \\
\text { requirements for collectors, } \\
\text { transporters, and recyclers. }\end{array}$ & $\begin{array}{l}8 \text { ec/gal motor oil } \\
\text { sales tax. }\end{array}$ & \\
\hline South Dakota & $\begin{array}{l}\text { Used oil destined for recycling or energy recovery } \\
\text { not regulated as hazardous waste. } \\
\text { Used oil mixed with hazardous waste or destined } \\
\text { for disposal regulated as hazardous waste. }\end{array}$ & $\begin{array}{l}\text { Landfill disposal banned after } \\
1997 \text {. Use as road oil or dust } \\
\text { suppressant prohibited. }\end{array}$ & & & \\
\hline Tennessee & $\begin{array}{l}\text { Used oil destined for recycling or energy recovery } \\
\text { not regulated as hazardous waste. } \\
\text { Used oil mixed with hazardous waste or destined } \\
\text { for disposal regulated as hazardous waste. }\end{array}$ & $\begin{array}{l}\text { Discharge to sewers or } \\
\text { waters and use as road oil, } \\
\text { dust suppressant, or weed } \\
\text { killer prohibited. Landfill } \\
\text { disposal by special permit } \\
\text { only. }\end{array}$ & $\begin{array}{l}\text { Transporters, marketers, } \\
\text { reprocessors, and re-refiners } \\
\text { required to tile annual reports and } \\
\text { notify the state within } 30 \text { days of } \\
\text { any operational status changes. }\end{array}$ & $\begin{array}{l}8 \phi / g a l \text { motor oil } \\
\text { sales tax }\end{array}$ & \\
\hline Texas & $\begin{array}{l}\text { Used oil not regulated as hazardous waste; } \\
\text { considered a municipal solid waste, except } \\
\text { industrial used oil, which is regulated as } \\
\text { hazardous waste if destined for disposal. }\end{array}$ & $\begin{array}{l}\text { Municipal landfill disposal; } \\
\text { discharge in sewers or } \\
\text { waters; and use as road oll, } \\
\text { dust suppressant, or weed } \\
\text { killer prohibited. }\end{array}$ & $\begin{array}{l}\text { Registration requirements for } \\
\text { collection centers. Industrial used } \\
\text { oll regulated as an industrial or } \\
\text { hazardous solid waste. }\end{array}$ & $\begin{array}{l}84 / \text { gal sales tax } \\
\text { on wholesale oil. }\end{array}$ & $\begin{array}{l}\text { Used oil fliter disposal in } \\
\text { municipal landfills } \\
\text { prohibited after } \\
\text { April } 1,1994 .\end{array}$ \\
\hline Utah & $\begin{array}{l}\text { Used oil destined for recycling or energy recovery } \\
\text { not regulated as hazardous waste. } \\
\text { Used oll mixed with hazardous waste or destined } \\
\text { for disposal regulated as hazardous waste. }\end{array}$ & $\begin{array}{l}\text { Landfill disposal; dlscharge in } \\
\text { sewers or waters; and use as } \\
\text { road oil, dust suppressant, or } \\
\text { weed killer prohibited. }\end{array}$ & $\begin{array}{l}\text { Coilectors, transporters, and } \\
\text { recyclers must be permitted or } \\
\text { registered, demonstrate financial } \\
\text { resources to cover potential } \\
\text { liabilities, and submit annual } \\
\text { reports. }\end{array}$ & $\begin{array}{l}\text { Recycling fee of } 4 € \\
\text { per quart on sale of } \\
\text { lubricating oil in } \\
\text { state. Fee of } \$ 25 \\
\text { for permit or } \\
\text { registration } \\
\text { number. }\end{array}$ & \\
\hline
\end{tabular}




\section{TABLE A.1 (Cont.)}

\begin{tabular}{|c|c|c|c|c|c|}
\hline State & General Comments & Disposal Bans & Other Stringent Requirements & Fees or Taxes & Used Oil Filters \\
\hline Vermont & $\begin{array}{l}\text { Used oil destined for recycling or energy recovery } \\
\text { not regulated as hazardous waste. } \\
\text { Used oil mixed with hazardous waste or destined } \\
\text { for disposal regulated as hazardous waste. }\end{array}$ & $\begin{array}{l}\text { Landill disposal and use as } \\
\text { road oil or dust suppressant } \\
\text { prohibited. }\end{array}$ & $\begin{array}{l}\text { Stringent regulations for burning } \\
\text { waste oll for energy recovery, } \\
\text { including air quality impact } \\
\text { evaluation and compliance with } \\
\text { state emission standards for new } \\
\text { bumers. }\end{array}$ & & \\
\hline Virginia & $\begin{array}{l}\text { Used oil destined for recycling or energy recovery } \\
\text { not regulated as hazardous waste. } \\
\text { Used oil mixed with hazardous waste or destined } \\
\text { for disposal regulated as hazardous waste. }\end{array}$ & $\begin{array}{l}\text { Landfill disposal as free } \\
\text { liquid, and use as road oil or } \\
\text { dust suppressant prohibited. }\end{array}$ & $\begin{array}{l}\text { Motor oil retailers required to post } \\
\text { locations of collection sites. }\end{array}$ & & \\
\hline Washington & $\begin{array}{l}\text { Used oil destined for recycling or energy recovery } \\
\text { not regulated as hazardous waste. } \\
\text { Used oil mixed with hazardous waste or destined } \\
\text { for disposal regulated as hazardous waste. }\end{array}$ & $\begin{array}{l}\text { Landfill disposal and use as } \\
\text { dust suppressant or weed } \\
\text { killer prohibited. Sale of } \\
\text { adsorbent-based kits } \\
\text { intended for home use as a } \\
\text { means of collecting or } \\
\text { disposing of used oil banned. }\end{array}$ & $\begin{array}{l}\text { No person may knowingly dispose of } \\
\text { used oil except by delivery to } \\
\text { collector for recycling, treatment, or } \\
\text { legal disposal. }\end{array}$ & & \\
\hline $\begin{array}{l}\text { West } \\
\text { Virginia }\end{array}$ & $\begin{array}{l}\text { Used oil destined for recycling or energy recovery } \\
\text { not regulated as hazardous waste. } \\
\text { Used oil mixed with hazardous waste or destined } \\
\text { for disposal regulated as hazardous waste. }\end{array}$ & Landfill disposal prohibited. & & & \\
\hline Wisconsin & $\begin{array}{l}\text { Used oil destined for recycling or energy recovery } \\
\text { not regulated as hazardous waste. } \\
\text { Used oil mixed with hazardous waste or destined } \\
\text { for disposal regulated as hazardous waste. }\end{array}$ & $\begin{array}{l}\text { Landfill disposal and use as } \\
\text { road oil, dust suppressant, or } \\
\text { weed killer prohibited. Waste } \\
\text { oil cannot be bumed in solid } \\
\text { waste treatment facility } \\
\text { without energy recovery. }\end{array}$ & $\begin{array}{l}\text { Motor oil retailers must collect used } \\
\text { oil for recycling or post signs to } \\
\text { nearest collection site. } \\
\text { Municipalities required to maintain a } \\
\text { minimum number of collection sites } \\
\text { based on population. }\end{array}$ & & \\
\hline Wyoming & $\begin{array}{l}\text { Used oil regulated as solid waste. Used oil not } \\
\text { regulated as hazardous waste if destined for } \\
\text { recycling and segregated to avoid } \\
\text { contamination. Use oil destined for disposal } \\
\text { must be tested to show that it does not exhibit } \\
\text { hazardous waste characteristics. }\end{array}$ & $\begin{array}{l}\text { Landfill disposal of free } \\
\text { liquid, and use of waste oil as } \\
\text { road oil, dust suppressant, or } \\
\text { weed killer prohibited. }\end{array}$ & $\begin{array}{l}\text { Permit requirements for certain } \\
\text { storage facilities, transporters, } \\
\text { burners, and recyclers. }\end{array}$ & & \\
\hline
\end{tabular}


TABLE A.2 State Waste Oil Incentives

\begin{tabular}{|c|c|c|}
\hline State & Collection Programs & State Purchasing Preferences \\
\hline Alabama & $\begin{array}{l}\text { Project Rose - public education on hazards of } \\
\text { dumping used oil and assistance to establish and } \\
\text { maintain collection sites. }\end{array}$ & \\
\hline Alaska & Many municipalities have collection sites. & \\
\hline Arizona & No official state program. & \\
\hline Arkansas & $\begin{array}{l}\text { No official state program. State Marketing Board } \\
\text { for Recycling coordinates local programs and } \\
\text { operates computer bulletin board on recycling and } \\
\text { regulations. }\end{array}$ & \\
\hline California & $\begin{array}{l}\text { California Used Oil Recycling Fund - grants to } \\
\text { establish DIY collection programs, to provide } \\
\text { containers and supplies for DIY collection and for } \\
\text { public education. Fund also sponsors "recycling } \\
\text { incentive" of } 16 \Phi / g a l \text { oil for "certified" } \\
\text { collection centers. }\end{array}$ & $\begin{array}{l}\text { No exclusions of recycled oils. } \\
\text { Requirements to purchase oils } \\
\text { with greatest recycled } \\
\text { content, provided product } \\
\text { quality is equivalent to or } \\
\text { better than virgin. }\end{array}$ \\
\hline Colorado & No official state program. & \\
\hline Connecticut & $\begin{array}{l}\text { Municipalities required to provide for collection } \\
\text { and recycle of used oil. Grant program for } \\
\text { purchase of collection tanks by municipalities. }\end{array}$ & \\
\hline Delaware & $\begin{array}{l}\text { Delaware Solid Waste Authority sponsors } \\
\text { collection sites and education }\end{array}$ & \\
\hline D.C. & $\begin{array}{l}\text { Operates three collection sites for used oil, used } \\
\text { oil filters, and antifreeze and sponsors education } \\
\text { program. }\end{array}$ & \\
\hline Florida & $\begin{array}{l}\text { Used Oil Management Program - includes } \\
\text { registration for used oil handlers, assistance to } \\
\text { build state-wide collection network, and public } \\
\text { education. }\end{array}$ & $\begin{array}{l}5 \% \text { price preference for } \\
\text { recycled and re-refined used } \\
\text { oil. }\end{array}$ \\
\hline Georgia & $\begin{array}{l}\text { Project PETRO - encourages recycling through } \\
\text { public education program (temporarily inactive). }\end{array}$ & \\
\hline Hawaii & $\begin{array}{l}\text { Monies assigned to counties to fund collection } \\
\text { centers and public outreach programs. Hawaii } \\
\text { Association of Retail Gas Dealers maintains used } \\
\text { oil hotline. }\end{array}$ & \\
\hline Idaho & No official state program. & \\
\hline
\end{tabular}


TABLE A.2 (Cont.)

\begin{tabular}{|c|c|c|}
\hline State & Collection Programs & State Purchasing Preferences \\
\hline Illinois & $\begin{array}{l}\text { Voluntary collection and recycling of oil } \\
\text { encouraged. Feasibility study conducted regarding } \\
\text { state collection and disposal assistance programs. }\end{array}$ & $\begin{array}{l}\text { State vehicles use recycled oil } \\
\text { whenever possible. }\end{array}$ \\
\hline Indiana & No official state program. & \\
\hline lowa & $\begin{array}{l}\text { Retailers must accept DIY oil or list locations of } \\
\text { nearest collection sites. Grants for collection } \\
\text { programs available through "Landfill Alternatives } \\
\text { Grant Program." }\end{array}$ & $\begin{array}{l}5 \% \text { price preference for } \\
\text { recycled lubricating oil. Use of } \\
\text { recycled oil promoted. }\end{array}$ \\
\hline Kansas & No official state program. & \\
\hline Kentucky & $\begin{array}{l}\text { Encourages collection and reuse of waste oil } \\
\text { through voluntary programs. }\end{array}$ & $\begin{array}{l}\text { State encourages and requires } \\
\text { (where possible) purchase of } \\
\text { recycled oil, when available } \\
\text { and competitively priced. }\end{array}$ \\
\hline Louisiana & $\begin{array}{l}\text { Used oil recycling program established but not } \\
\text { funded. }\end{array}$ & $\begin{array}{l}\text { Preference to re-refined oil } \\
\text { (greater than } 25 \% \text { recycled } \\
\text { content) that meets quality } \\
\text { requirements and is priced } \\
\text { within } 5 \% \text { of virgin oil.cost. }\end{array}$ \\
\hline Maine & $\begin{array}{l}\text { Maine Oil Recycling Program - provides a subsidy } \\
\text { for companies to purchase used oil burners to } \\
\text { encourage recycling. }\end{array}$ & \\
\hline Maryland & $\begin{array}{l}\text { Used Oil Recycling Act - provides for public } \\
\text { education program, establishment of a used oil } \\
\text { information center, and technical assistance to } \\
\text { used oil collection programs. State inspection } \\
\text { centers and other locations required to collect } \\
\text { used oil. }\end{array}$ & $\begin{array}{l}\text { Purchase of re-refined oil is } \\
\text { encouraged and required (when } \\
\text { possible) by law. }\end{array}$ \\
\hline Massachusetts & No official state program. & \\
\hline Michigan & $\begin{array}{l}\text { State used oil recycling law enacted to promote } \\
\text { recycling. However, implementation of provisions } \\
\text { stalled by lack of funding. }\end{array}$ & \\
\hline Minnesota & $\begin{array}{l}\text { Grants to local governments for collection site } \\
\text { storage tank purchase. Provides fact sheets to } \\
\text { assist public in oil recycling and curriculums for } \\
\text { schools. }\end{array}$ & \\
\hline Mississippi & No official state program. & \\
\hline
\end{tabular}


TABLE A.2 (Cont.)

State

$\begin{array}{ll}\text { Missouri } & \text { No official state program. } \\ \text { Montana } & \text { No official state program. } \\ \text { Nebraska } & \text { No official state program. }\end{array}$

Nevada

No official state program.

New Hampshire

New Jersey

New Mexico

New York

North Carolina

North Dakota

Onio

Oklahoma

Oregon
Beginning 1995, program will provide municipal grants for collection programs and training.

Numerous municipalities sponsor collection sites or curbside collection programs. Service facilities with active used oil collection tanks required to accept DIY used oil up to 10 quarts/person/day.

No official state program.

State requires oil retailers and service stations to install and maintain used oil retention and collection facilities.

Department of the Environment is authorized to establish an incentives program to encourage DIY used oil recycling and to develop a grant program.
Recycled material considered in purchasing.
$5 \%$ purchasing preference for recycled content.

Contracts for re-refined oil.

State law directs the Department of Environment to encourage procurement of recycled automotive, industrial, and fuel oils for all state and local government uses.
No official state program.

No official state program. State districts are required to prepare plan for managing householdgenerated used oil.

No official state program.

Goal to collect $50 \%$ of DIY used oil by $1996,70 \%$ by 2000 . Recycling Opportunity Act dictates public education initiatives and curbside or dropoff collection, based on population.
Preference given to recycled products purchasing bids.

$5 \%$ preference for re-refined lube oil and preference for used oil fuel. 
TABLE A.2 (Cont.)

State Collection Programs

State Purchasing Preferences

Pennsylvania

Voluntary collection sites, registration with state. State sponsors hotline and promotes recycling through Used Oil Recovery Program.

Rhode Island

South Carolina

South Dakota

Tennessee

Texas

Utah

Vermont

Virginia

Washington

West Virginia

Wisconsin

Wyoming
Used Oil Recycling Act - requires state to conduct public education program and establish used oil information center. State motor vehicle inspection facilities and other facilities required to collect used oil, with costs covered by state.

$5 \% / g a l$ incentive for retail facilities to establish separate tanks for DIY oil. Other programs under development.

State-wide pilot program conducted in 1993 established voluntary collection sites at service stations.

Used Oil Collection Act (based on API model legislation) - includes funds for grants, education, hotline, and oil collection site subsidies.

Grant program to encourage oil recycling. Reimbursements for costs of proper disposal of contaminated DIY oil.

State fund established to pay quarterly incentives to approved DIY collection centers and curbside programs.

Grants for purchase of collection tanks and proper disposal of contaminated oil generated by DIY oil changers.

No official state program.

Local governments required to include used oil recycling "element" as part of hazardous waste plans.

Program under development.

Large municipalities required to set up used oil collection sites.

No official state program.
$5 \%$ preference for materials with recycled content.

Recycled oil to be purchased to extent possible.

Purchases used oil whenever possible.

Mandate to procure used oil products where practicable.

Mandated preference for recycled products.

State agencies purchase motor oil containing re-refined oil. 
Appendix B:

Waste Oil Study Contacts 


\title{
Appendix B:
}

\section{Waste Oil Study Contacts}

The authors acknowledge the following people who shared their waste oil experiences and contributed their ideas on research needs for increasing waste oil recovery and recycling.

\author{
Alabama \\ Sheri Powell, Project ROSE Coordinator, Tuscaloosa \\ Karen Schoening, Recycling Coordinator, Huntsville
}

\section{Alaska}

Dan Garcia, Department of Environmental Conservation, Solid and Hazardous Waste Management, Juneau

\section{Arizona}

Robert Verville, Used Oil Compliance Manager, Department of Environmental Quality, Phoenix

\section{Arkansas}

Paul Carson, Mid America Distillations, Inc., Hot Springs

\section{California}

Fernando Berton, California Integrated Waste Management Board, Sacramento

Bob Boughton, California Integrated Waste Management Board, Sacramento Jane Bryne, Evergreen Oil, Newport Beach

Stuart M. Cannes, Unocal, City of Industry John L. Cooper, Chevron Products Company, San Francisco

Bruce DeMenno, Demenno/Kerdoon, Compton Larry Levenstein, Clark Technology Systems Inc., Santa Paula

Rich Loveton, Full Prime System, Inc., Penn Valley Don Peri, California Integrated Waste Management Board, Sacramento Jeff Underhill, Evergreen Oil, Newport Beach

\section{Canada}

Dave McIntyre, Oil Recovery Division of Safety-Kleen Canada, Inc., Breslau, Ontario Matt Waldner, Mohawk Lubricants Ltd., North Vancouver, British Columbia 


\section{Connecticut}

Judy Belaval, Connecticut Department of Environmental Protection, Bureau of Waste

Management, Hartford

Tom Metzner, Connecticut Department of Environmental Protection, Bureau of Waste Management, Hartford

\section{Delaware}

Bob Palmer, Delaware Solid Waste Authority, Dover

Donald Short, Delaware Natural Resources and Environmental Control, Hazardous Waste Management Branch, Dover

Bill Tanzey, Star Enterprises, Delaware City

\section{District of Columbia}

Dana Arnold, EPA

Bradley Jones, Used Oil Program Coordinator, American Petroleum Institute

Carl Williams, D.C. Energy Office

\section{Florida}

Joan Flint, Department of Environmental Regulation, Tallahassee

Bob Foster, Permafix Environmental, Gainesville

\section{Georgia}

Rick Cothran, Project PETRO Coordinator, Georgia Department of Natural Resources, Environmental Protection Division, Atlanta

\section{Illinois}

Dennis Brinkman, Safety Kleen Corp., Elk Grove Village

Tom Kalnes, UOP, Inc., Des Plaines

Frank Lappin, Enviropur Waste Refining and Technology, McCook

Fred Quam, Marketing Manager, Energy Division, Growmark, Bloomington

David J. Shipley, Amoco Oil Corporation, Chicago

\section{Indiana}

Dave Carson, Consolidated Recycling, Troy

\section{Iowa}

Michael Berkshire, East Central Iowa Council of Governments, Cedar Rapids

Christoffer Frantsvog, Spectrum Industries, Decorah

Marilyn Krogulski, Waste Management Assistance Division, Iowa Department of Natural

Resources, Des Moines

Amy Rogers, Amana Refrigeration, Inc., Amana 


\section{Kansas}

Jack Beachey, Franklin Associates, Manhattan

\section{Kentucky}

Charles Peters, Kentucky Department of Environmental Protection, Waste Management Division, Frankfort

Tony Puckett, Valvoline Environmental Services, Lexington

\section{Louisiana}

John Rogers, Department of Environmental Quality, Office of Solid and Hazardous Waste, Baton Rouge

\section{Maine}

Rick Kaselis, Bureau of Hazardous Material and Solid Waste Control, Department of

Environmental Protection, Augusta

\section{Maryland}

Cheryl Kidwell, Maryland Environmental Service, Annapolis

Larry Northrup, Convenient Automotive Services Institute, Bethesda

\section{Massachusetts}

Kevin Dietly, Northbridge Environmental Consultants, Lexington

Dikran Kaligian, Bureau of Waste Prevention, Department of Environmental Protection, Boston

\section{Michigan}

Brian Burke, Michigan Department of Natural Resources, Waste Management Division, Lansing Pat Casey, Savant, Inc., Midland

\section{Minnesota}

Tony Hainault, Office of Waste Management, St. Paul

Julie MacKenzie, Minnesota Pollution Control Agency, St. Paul

\section{Missouri}

Clark Duffy, Missouri Oil Council, Jefferson City

Karen Northrup, Missouri Department of Natural Resources, Hazardous Waste Program, Jefferson City

\section{Montana}

Pierre Amicucci, Department of Health and Environmental Sciences, Helena 


\section{Nebraska}

Teri Swarts, Hazardous Waste Section, Department of Environmental Quality, Lincoln

\section{Nevada}

Kris Kuiper, Nevada Division of Environmental Protection, Bureau of Waste Management, Carson City

\section{New Hampshire}

Christopher Way, Waste Management Specialist, Department of Environmental Services, Concord

\section{New Jersey}

Ann Pfaff, New Jersey State Department of Environmental Protection, Trenton

\section{New York}

Tom Gibbons, Pall Corporation, BaySide

Bill Mirabile, New York State Department of Environmental Conservation, Bureau of Waste Reduction and Recycling, Albany

\section{North Carolina}

Paul Chrisman, Department of Environment, Health and Natural Resources, Raleigh Linda Culpepper, Department of Environment, Health and Natural Resources, Raleigh Greg Griggs, Filter Manufacturers Council, Research Triangle Park

\section{Ohio}

Alan Gressel, Research Environmental Industries, Cleveland

Dr. Bruce Perlson, Quantum Chemical, Cincinnati

Dann R. Stapp, BP Oil America, Cleveland

\section{Oregon}

Peter Spendelow, Department of Environmental Quality, Portland

\section{Pennsylvania}

Joe Brancato, Quaker State Corporation, Oil City

Ben Briseno, Sun Co., Inc., Philadelphia

Jerald Claes, Graham Packaging, York

William D. LaCour, Used Oil Recovery Coordinator, Department of Environmental Resources,

Harrisburg

Vasil Mriz, Quaker State Corporation, Oil City 


\section{Rhode Island}

Tom Armstrong, Department of Environmental Management, Office of Environmental Coordination, Providence

Tony Caronia, Allied Signal Automotive, East Providence

Tim Warren, Allied Signal Automotive, East Providence

\section{South Carolina}

Richard Chesley, Department of Health and Environmental Control, Columbia

Willard Strong, Santee Cooper Utility, Moncks Corner

\section{South Dakota}

Carrie Jacobson, Department of Environment and Natural Resources, Division of Environmental Regulation, Pierre

Terry Keller, General Recycling Coordinator, Department of Environment and Natural Resources, Pierre

\section{Tennessee}

Alan Ball, Department of Environment and Conservation, Division of Solid Waste Assistance, Nashville

Don Manning, Department of Environment and Conservation, Division of Solid Waste Assistance, Nashville

\section{Texas}

Gary Davis, Texas Natural Resource Conservation Commission, Recycling and Waste Minimization Section, Austin

Steve Eisenstein, Shell Development Company, Houston

Brett Morton, Pennzoil, Inc., Houston

Claude J. Roberts, Jr., Texaco Lubricants Company, Houston

Sam Walker, Nalco Chemical Company, Sugar Land

Tom Wulfers, Lyondell Lubricants, Houston

\section{Utah}

Curt Morgan, Interline Resources Corporation, Alpine

Steve Yeoman, Interline Resources Corporation, Alpine

\section{Vermont}

Doug Elliot, Department of Environmental Conservation, Agency of Natural Resources, Waterbury John Miller, Department of Environmental Conservation, Waterbury 


\section{Virginia}

Dave Greer, Mobil Oil Corporation, Fairfax

Nancy Williams, Department of Environmental Quality, Richmond

William Vehrs, Mobil Oil Corporation, Fairfax

\section{Washington}

William Green, Solid Waste Services, Department of Ecology, Olympia

Mike Porter, Partec Corporation, Vancouver

David Stitzel, Stitzel Environmental Consulting, Seattle

\section{Wisconsin}

Andy Swartz, Recycling Section, Bureau of Solid and Hazardous Waste Management, Department of Natural Resources, Madison 


\section{DISTRIBUTION FOR ANL/ESD-29}

\section{Internal}
ANL Technical Publications Service
R. Weeks
S. Juricic (5)
M. Fitzpatrick
D. Graziano (101)

\section{External}

U.S. Department of Energy Office of Scientific and Technical Information (12) Manager, U.S. Department of Energy Chicago Field Office

ANL-E Libraries (2)

ANL-W Library 